\title{
Holocene benthic foraminiferal and ostracod assemblages in a paleo-hydrothermal vent system of Campi Flegrei (Campania, South Italy)
}

\author{
Giuseppe Aiello, Diana Barra, Roberta Parisi, Roberto Isaia, and Aldo Marturano
}

\begin{abstract}
The succession of the Late Quaternary La Starza terrace, located within the Campi Flegrei caldera, on the Tyrrhenian side of southern Italy, represents a wellknown example of deposition under the combined influence of bathymetric and physico-chemical variations due to volcanic activities. One hundred and seven samples collected in six outcrops and some tunnel excavation fronts, with an age between $\sim 12$ and $\sim 4$ k.y.a, comprise both barren and fossiliferous sediments. The latter contain siliceous and/or calcareous microfossil remains, including benthic foraminiferal and ostracod assemblages indicative of a marine paleodepth ranging from the upper infralittoral to the upper circalittoral zone, with phases of intense environmental stress typical of a hydrothermal system. A detailed reconstruction of the Holocene paleoenvironmental evolution of the succession is presented. The majority of foraminiferal and ostracod species is illustrated and brief taxonomic and ecological notes are given for each of them.
\end{abstract}

Giuseppe Aiello. Dipartimento di Scienze della Terra, dell'Ambiente e delle Risorse, Università di Napoli Federico II, via Cinthia, 80126, Napoli - aie64llo@hotmail.com

Diana Barra. Dipartimento di Scienze della Terra, dell'Ambiente e delle Risorse, Università di Napoli

Federico II, via Cinthia, 80126 - dibarra@unina.it

Roberta Parisi. Dipartimento di Scienze della Terra, dell'Ambiente e delle Risorse, Università di Napoli

Federico II, via Cinthia, 80126 - robyparisi@gmail.com

Roberto Isaia. Istituto Nazionale di Geofisica e Vulcanologia, Sezione di Napoli Osservatorio Vesuviano, Via Diocleziano 328, 80124 Napoli, Italy - roberto.isaia@ingv.it

Aldo Marturano. Istituto Nazionale di Geofisica e Vulcanologia, Sezione di Napoli Osservatorio Vesuviano, Via Diocleziano 328, 80124 Napoli, Italy - aldo.marturano@ingv.it

Keywords: benthic foraminifers; ostracods; Late Quaternary; paleoenvironmental evolution; hydrothermal system

Submission: 14 November 2017 Acceptance: 9 October 2018

Aiello, Giuseppe, Barra, Diana, Parisi, Roberta, Isaia, Roberto, and Marturano, Aldo. 2018. Holocene benthic foraminiferal and ostracod assemblages in a paleo-hydrothermal vent system of Campi Flegrei (Campania, South Italy). Palaeontologia Electronica 21.3.41A 1-71. https://doi.org/10.26879/835

palaeo-electronica.org/content/2018/2332-la-starza-forams-and-ostracods

Copyright: November 2018 Paleontological Society.

This is an open access article distributed under the terms of Attribution-NonCommercial-ShareAlike 4.0 International (CC BY-NC-SA 4.0 ), which permits users to copy and redistribute the material in any medium or format, provided it is not used for commercial purposes and the original author and source are credited, with indications if any changes are made.

creativecommons.org/licenses/by-nc-sa/4.0/ 


\section{INTRODUCTION}

The occurrence of well-developed sedimentary sequences yielding calcareous fossil remains in volcanic areas may provide a useful tool for evaluating the relationship among ground deformations, volcanic activities and paleoenvironmental evolution. In the late Quaternary succession of the La Starza terrace at the Campi Flegrei caldera, located on the Tyrrhenian side of southern Italy, abundant meiofaunal remains have been found, with the notable presence of relatively well-preserved benthic foraminiferal tests and ostracod shells. As the ecological characteristics of the Quaternary species are generally well known, we undertook a detailed micropaleontological survey to determine the faunal content of the deposits and to establish the environmental changes occurred during the Holocene in this sector of the Phlegrean Fields. Benthic foraminifers (protists) and ostracods (crustaceans) show different sensitivity to ecological parameters such as water depth, salinity, saturation in $\mathrm{CaCO}_{3}$, dissolved oxygen, type of bottom sediment and consequently the coupled analyses of the two taxa can be used to improve the detail and accuracy of the paleoenvironment model.

\section{GEOLOGICAL SETTING}

The La Starza marine terrace is one of the major structures within the Campi Flegrei caldera (Figure 1), an active volcanic area resulted from two main late Pleistocene events, the Campanian Ignimbrite super eruption ( 40 k.y.a) (De Vivo et al., 2001; Giaccio et al., 2008; Costa et al., 2012) and the Neapolitan Yellow Tuff eruption ( 15 k.y.a) (Orsi et al., 1992; Scarpati et al., 1993; Deino et al., 2004). Some marine ingressions formed the terrace that ends on the coastward side with a fossil marine cliff where interlayered tephra and Holocene marine sediments outcrop. The depositional history of the La Starza terrace has been influenced by the ground deformations linked with the eruptive events, by slow bradyseismic movements and by the sea-level variations occurred in the Mediterranean during the late Quaternary (Cinque et al., 1985; Orsi et al., 1996; Di Vito et al., 1999; Bellucci et al., 2006; Isaia et al., 2009; 2016; Lambeck et al., 2011; Marturano et al., 2018). The succession reflects deposition during three main phases of intense volcanic activity, ranging in the intervals of 15.0-10.6 k.y.a (Epoch I), 9.6-9.2 k.y.a (Epoch II) and 5.5-3.5 k.y.a (Epoch III), respectively (Di Vito et al., 1999; Smith et al., 2011; Isaia et al., 2015) and two rest periods (Figure 2). The

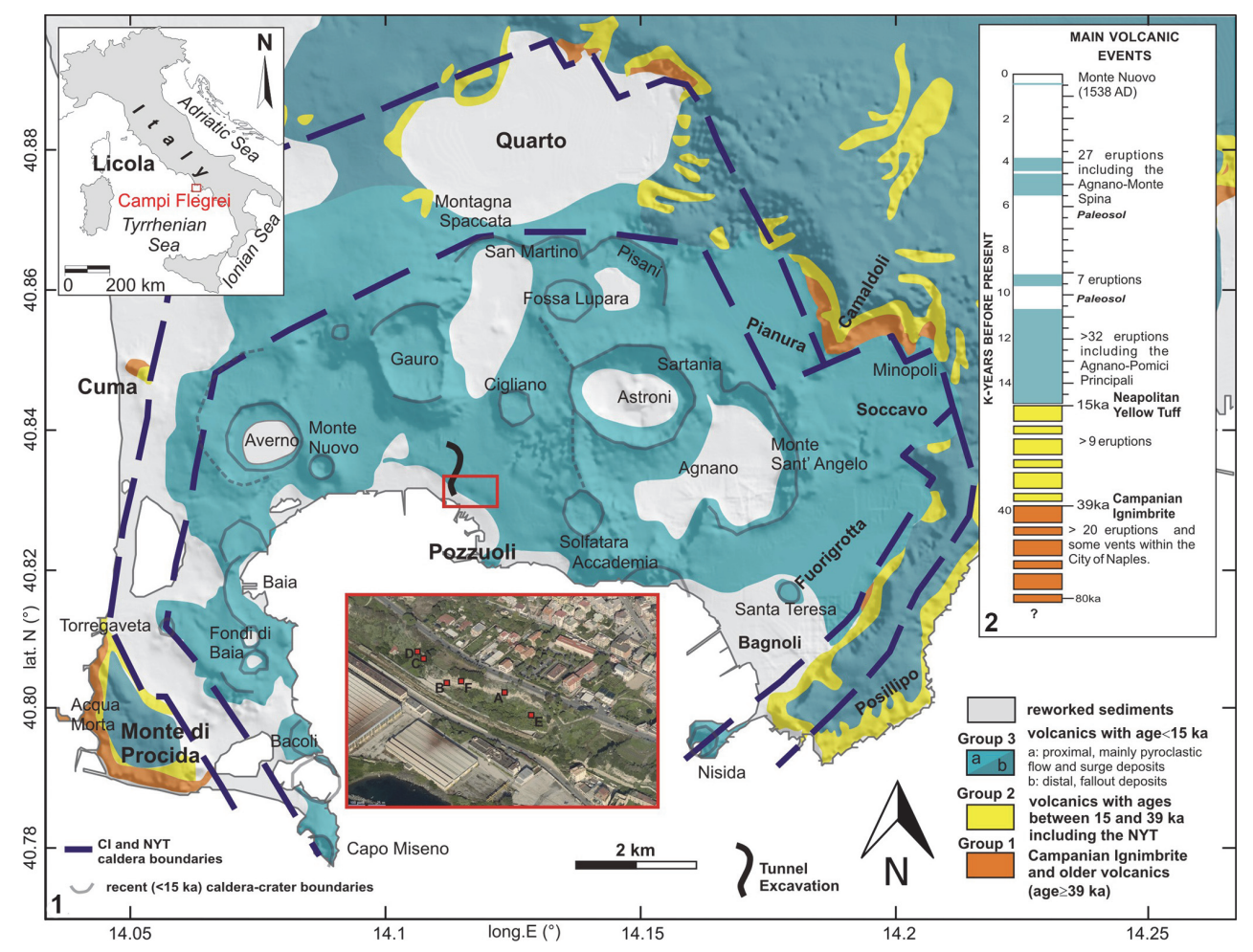

FIGURE 1. 1) Schematic geological map of Campi Flegrei (after Vitale and Isaia, 2014, modified); location of the sections and of the Tunnel Excavation. 2) Chronology of the main volcanic events in the CF. 


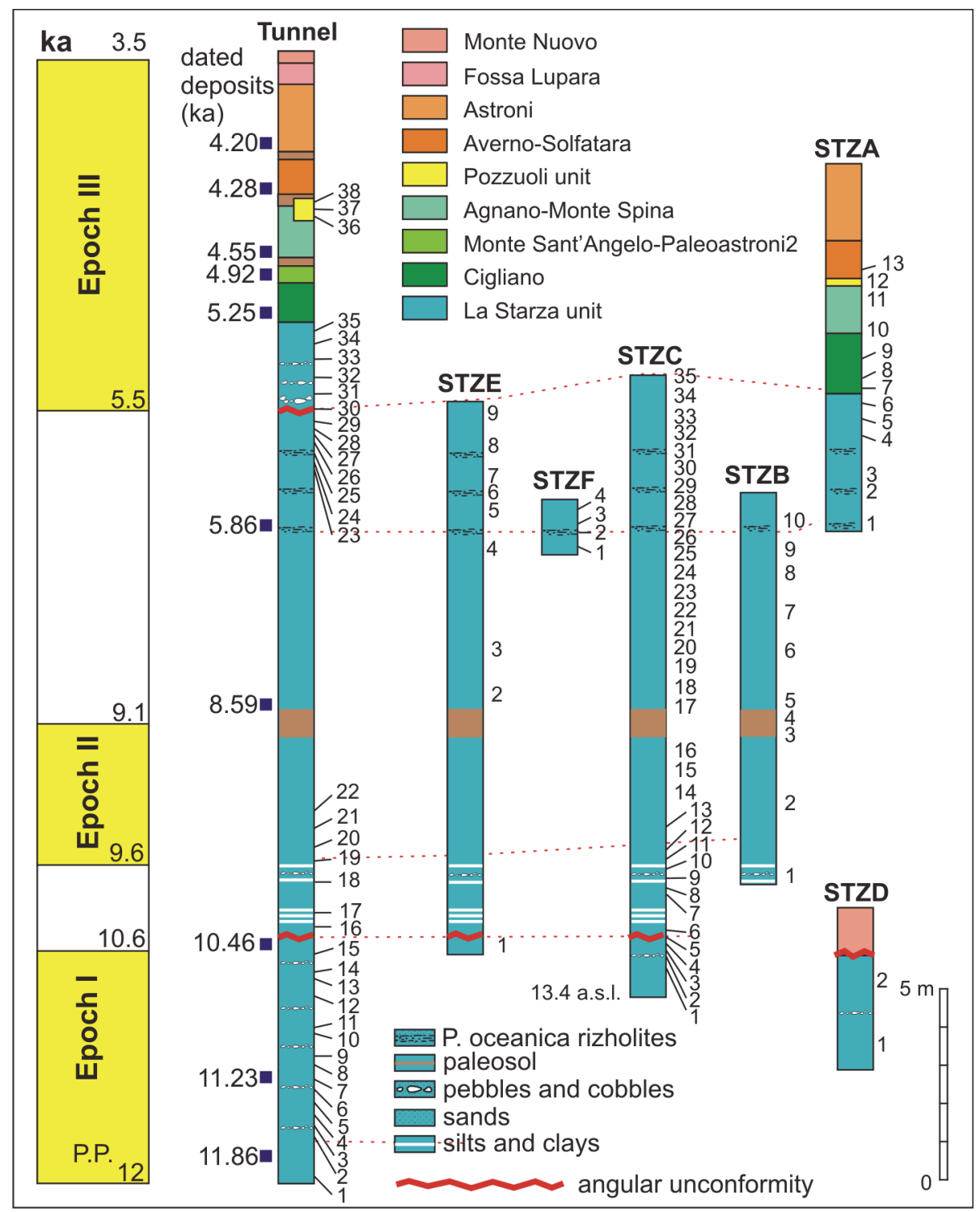

FIGURE 2. Chronostratigraphic correlation of the La Starza sections (including Tunnel Section) with sampling location and dated levels. Chronostratigraphic data are according Rosi and Sbrana, 1987; Giudicepietro, 1993; Di Vito et al., 1999; de Vita et al., 1999; Isaia et al., 2009; Passariello et al., 2010; Smith et al., 2011.

last volcanic event, the Monte Nuovo eruption, occurred in 1538, forming in few days a cone tuff located in the western part of the town of Pozzuoli. The deposits of this eruption locally cap the sequences of the La Starza Terrace.

The presence of well exposed marine sediments at La Starza have promoted the paleontological studies since the brief notes of Scacchi (1841, 1849) and the investigations of Costa (1853a, b) who presented lists of both foraminiferal and ostracod species. Further data on fossil assemblages were reported by De Angelis D'Ossat (1894), De Lorenzo and Simotomai Tanakadate (1915; also including a list of species previously compiled by Charles Babbage), Bellini (1929) and Minieri (1950). The first modern study of the fossil assemblages of the La Starza deposits was carried out by Rodriquez (1964), focusing mainly on molluscs and foraminifers. In more recent times contributions on foraminifer and ostracod assemblages have been carried out by Amore et al. $(1988,1990)$ and Ciampo (2004).

\section{MATERIAL AND METHODS}

One hundred and seven samples have been collected from six sections of the La Stanza Cliff (Figures 1-2) and from several tunnel excavation 
fronts (from here onwards referred to as "Tunnel Section") for micropaleontological analyses with special regard to benthic foraminiferal and ostracod assemblages.

The Tunnel Section, $\sim 31.5 \mathrm{~m}$ thick, consists of deposits ranging from Epoch I to Epoch III; 38 samples were collected. Section D (thickness: 4.3 $\mathrm{m}$ ) deposited during Epoch I and the first rest interval; two samples pertain to this section. Both Section C (thickness: $16.3 \mathrm{~m}$ ) and Section E (thickness: $14.5 \mathrm{~m}$ ) range from the upper part of Epoch I to the base of Epoch III; in the Section C 35 samples have been studied, five belong to the Section E. Section B, $10.3 \mathrm{~m}$ thick, includes deposits pertaining to the first period of volcanic quiescence, Epoch II and second rest phase; 10 samples were collected in this section. Section $F$ is a short section $(1.5 \mathrm{~m})$ entirely deposited during the second quiescent phase; four levels were sampled. The Section A ranges from the last part of the second rest phase to Epoch III, with a thickness of $9.7 \mathrm{~m}$; 13 samples were collected.

Ages of volcanic and marine deposits cropping out in the La Starza cliff, reported in Figure 2, derive from literature data (Rosi and Sbrana, 1987; Giudicepietro, 1993; Di Vito et al., 1999; de Vita et al., 1999; Isaia et al., 2009; Passariello et al., 2010; Smith et al., 2011). Stratigraphic data show that the age of the succession ranges from $\sim 12$ to $\sim 4$ k.y.a, locally overlain by the deposits of the historical Monte Nuovo eruption (Figure 2). The Pomici Principali deposits ( 12.3 k.y.a) do not outcrop either in the sections or in the Tunnel Section.

All the sediment samples $(200 \mathrm{~g}$ - dried weight) were disaggregated in boiling water with sodium carbonate, washed through 230 and 120 mesh sieves (63 and $125 \mu \mathrm{m}$, respectively) and the residue examined under transmitted light microscope. Diatoms, molluscs, bryozoans, echinoderms, planktonic foraminifers, sponges, radiolarians and serpulids occurrences have been reported as semiquantitative data (Table 1 - please note Tables 2-7 are supplied as spread sheets in one zipped file online). When possible a minimum of 300 benthic foraminiferal specimens and ostracod valves were picked from the coarsest fraction $(>125 \mu \mathrm{m})$ and counted for quantitative analysis. A microsplitter was used to obtain subsamples when necessary. Data consist of number of foraminifer specimens (Tables 2, 3) and ostracod Minimum Number of Individuals (MNI, Tables 4, 5) and Total Number of Valves (TNV, Tables 6, 7). $\mathrm{MNI}$ is the greater number between right and left adult valves plus the number of adult carapaces; when only juvenile shells are recorded the $\mathrm{MNI}$ equals one. TNV includes all the juvenile and adult valves.

The species have been identified according to classic and modern literature both for benthic foraminifers (i.a., Sen Gupta et al., 2009a; Hayward et al., 2010; Debenay, 2012; Milker and Schmiedl, 2012) and, with special regard to the Mediterranean area, for ostracods (i.a. Bonaduce et al., 1976a; Breman, 1976; Aiello and Barra, 2010). Species are listed in Appendix 1.

Discrimination of autochthonous and allochthonous ostracod species was based on the state of preservation, the available distribution data and the presence of shells belonging to different development stages. Allochthonous species (not considered for paleoenvironmental analysis) and their distributions are summarized in Table 8.

Paleoecological reconstructions have been carried out taking into account semiquantitative and quantitative data, the latter analysed using the free software PAST version 3.01 (Hammer et al., 2001). Q-mode cluster analysis was performed only on samples of the Section $C$ that yielded both benthic foraminiferal and ostracod remains; it has been applied to benthic foraminiferal and ostracod assemblage data using the Bray-Curtis similarity coefficient. Benthic foraminiferal and ostracod species with relative abundance greater than $5 \%$ in at least one sample have been considered.

The comparison among statistical analyses, taxonomic composition, assemblage features, literature data and unpublished data from north-western coastal areas of the Campania Region, allowed the evaluation of paleoenvironmental variations. We have taken in account assemblage parameters summarized in Table 9 and reported in Tables 1012, that are: Abundance (I), Relative Abundance $(R A)$, Dominance (D), Diversity ( $\left.S, H^{\prime}\right)$, Equitability $(\mathrm{J})$, Ammonia-Elphidium Index (AE), ForaminiferOstracod Ratio (FO), Circalittoral Foraminifer Relative Abundance (CFRA), Circalittoral Ostracod Relative Abundance (CORA) and Tolerant Foraminifer Relative Abundance (TFRA). The studied specimens are housed in the Aiello Barra Micropaleontological Collection (A.B.M.C.), Dipartimento di Scienze della Terra, dell'Ambiente e delle Risorse, Università degli Studi di Napoli Federico II.

\section{RESULTS}

The lowest outcropping deposits of the La Starza succession consist of alternating fine, medium and coarse-grained sands (1 $\mathrm{m}$ thick), passing upward into medium coarse sands, $2.5 \mathrm{~m}$ 
TABLE 1. Semiquantitative distribution of microfossils remains (VR=very rare; $R=$ rare; $U=u n c o m m o n ; C=c o m m o n)$.

\begin{tabular}{|c|c|c|c|c|c|c|c|c|c|c|c|c|}
\hline Section & Samples & 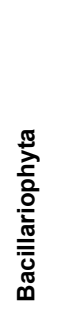 & $\frac{\frac{\pi}{2 \pi}}{\frac{\pi}{\infty}}$ & 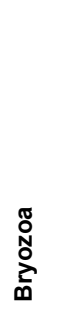 & 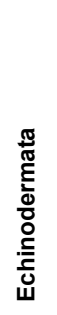 & 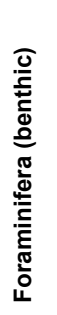 & 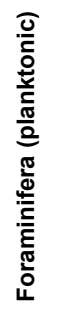 & 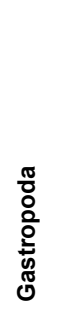 & 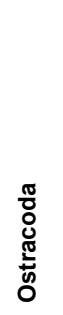 & $\begin{array}{l}\frac{\pi}{0} \\
\stackrel{\square}{0} \\
0\end{array}$ & $\begin{array}{l}\frac{\pi}{\frac{\pi}{\pi}} \\
\frac{\pi}{0} \\
\stackrel{0}{0} \\
\frac{\pi}{\tilde{\pi}}\end{array}$ & 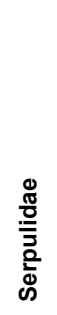 \\
\hline \multirow[t]{5}{*}{ Tunnel excavation } & Tun 2 & & & & & & & & & VR & & \\
\hline & Tun 22 & & & & & & & & & C & & \\
\hline & Tun 23 & VR & & & & & & & & VR & & \\
\hline & Tun 27 & & & & & & & & & $\mathrm{U}$ & & \\
\hline & Tun 35 & & & & & & & & & $\mathrm{U}$ & & \\
\hline \multirow[t]{24}{*}{ STZC } & STZC 7 & & & & & VR & & & & VR & & \\
\hline & STZC 9 & & & & & & & & & VR & VR & \\
\hline & STZC 13 & & & & & $U$ & & & & VR & & \\
\hline & STZC 15 & & & & $U$ & $U$ & $\mathrm{R}$ & VR & $\mathrm{R}$ & $\mathrm{R}$ & & \\
\hline & STZC 16 & VR & $\mathrm{R}$ & & VR & $\mathrm{R}$ & & $\mathrm{R}$ & VR & $U$ & & \\
\hline & STZC 17 & & $A$ & & $U$ & $\mathrm{R}$ & & $\mathrm{C}$ & VR & & & $\mathrm{C}$ \\
\hline & STZC 18 & $\mathrm{R}$ & $U$ & & $\mathrm{R}$ & $\mathrm{C}$ & $\mathrm{R}$ & $\mathrm{R}$ & $\mathrm{R}$ & $\mathrm{C}$ & $\mathrm{R}$ & \\
\hline & STZC 19 & & $U$ & & $\mathrm{C}$ & $\mathrm{C}$ & $\mathrm{R}$ & $U$ & $U$ & $U$ & $\mathrm{R}$ & \\
\hline & STZC 20 & & $\mathrm{C}$ & & $U$ & C & $\mathrm{R}$ & $\mathrm{C}$ & $\mathrm{C}$ & C & $\mathrm{R}$ & \\
\hline & STZC 21 & & $\mathrm{R}$ & & $U$ & C & $\mathrm{R}$ & $\mathrm{R}$ & $U$ & $U$ & $\mathrm{R}$ & \\
\hline & STZC 22 & & $\mathrm{R}$ & & $U$ & $\mathrm{C}$ & $\mathrm{R}$ & & $\mathrm{C}$ & $\mathrm{C}$ & $\mathrm{R}$ & \\
\hline & STZC 23 & VR & $\mathrm{R}$ & & $\mathrm{R}$ & C & $\mathrm{R}$ & VR & $U$ & $U$ & & \\
\hline & STZC 24 & $\mathrm{R}$ & VR & & $U$ & C & $\mathrm{R}$ & VR & $\mathrm{C}$ & $U$ & $\mathrm{R}$ & \\
\hline & STZC 25 & & & & $\mathrm{R}$ & C & $\mathrm{R}$ & & $U$ & U & VR & VR \\
\hline & STZC 26 & $\mathrm{R}$ & & & $U$ & C & U & & C & $\mathrm{U}$ & VR & \\
\hline & STZC 27 & VR & & & $U$ & $U$ & $\mathrm{R}$ & & $U$ & $U$ & $\mathrm{R}$ & VR \\
\hline & STZC 28 & VR & $\mathrm{R}$ & & $U$ & C & $\mathrm{R}$ & & $U$ & U & $\mathrm{U}$ & \\
\hline & STZC 29 & $\mathrm{R}$ & $\mathrm{R}$ & & $U$ & C & $\mathrm{R}$ & $\mathrm{R}$ & $\mathrm{C}$ & U & $\mathrm{R}$ & VR \\
\hline & STZC 30 & VR & $U$ & & C & C & $\mathrm{R}$ & & $U$ & $U$ & $\mathrm{R}$ & \\
\hline & STZC 31 & VR & & & $U$ & C & $U$ & & $U$ & $\mathrm{C}$ & & \\
\hline & STZC 32 & VR & $\mathrm{R}$ & & $U$ & $U$ & VR & & $U$ & $U$ & & VR \\
\hline & STZC 33 & $U$ & $U$ & & $\mathrm{R}$ & C & & & C & $U$ & $U$ & \\
\hline & STZC 34 & $\mathrm{R}$ & & & $U$ & C & $U$ & & C & C & $U$ & \\
\hline & STZC 35 & & & & & & & & & $C$ & & \\
\hline STZE & STZE 1 & & C & VR & $U$ & $\mathrm{C}$ & $\mathrm{R}$ & $U$ & $\mathrm{R}$ & $\mathrm{C}$ & & $\mathrm{R}$ \\
\hline
\end{tabular}

thick, in places characterized by cross-lamination and pumice lenses. They are covered by a $1 \mathrm{~m}$ thick level of yellowish laminated silt and fine sand, in turn overlain by $2 \mathrm{~m}$ of medium to coarse sands and pumice lenses, topped by medium-coarse orange-brownish massive sands, $3 \mathrm{~m}$ thick.

In the tunnel excavation the lowest part of the succession shows fine-medium grained sands fol- lowed by coarse-grained channelized sands passing, through a flat-lying unconformity, to fine sediments that correspond to the yellowish level outcropping in the La Starza cliff. In both Tunnel Section and La Starza cliff the sequence continues with medium to fine massive sands (5 m thick) containing anthozoan, mollusc and echinoid remains, and with three layers of fine to medium sands with 


\section{TABLE 1 (continued).}

\begin{tabular}{|c|c|c|c|c|c|c|c|c|c|c|c|}
\hline & STZE 2 & & VR & U & C & $\mathrm{R}$ & & & C & VR & \\
\hline & STZE 3 & VR & VR & & & & & & C & & \\
\hline & STZE 4 & & VR & & & & & & U & & $\mathrm{R}$ \\
\hline & STZE 5 & & & & & & & & C & & VR \\
\hline \multirow[t]{9}{*}{ STZB } & STZB 2 & & & & & & & & VR & & \\
\hline & STZB 3 & & & & & & & & VR & & \\
\hline & STZB 4 & & & & & & & & U & & \\
\hline & STZB 5 & $\mathrm{R}$ & C & VR & C & & U & U & C & $\mathrm{R}$ & \\
\hline & STZB 6 & U & & $\mathrm{R}$ & C & U & & U & C & U & \\
\hline & STZB 7 & & & & & & & & C & C & \\
\hline & STZB 8 & & & & & & & & C & U & \\
\hline & STZB 9 & & & & & & & & U & $\mathrm{R}$ & \\
\hline & STZB 10 & & & & & & & & $\mathrm{R}$ & VR & VR \\
\hline \multirow[t]{4}{*}{ STZF } & STZF1 & $\mathrm{R}$ & & U & C & & & & C & $\mathrm{R}$ & \\
\hline & STZF2 & & & $\mathrm{R}$ & $\mathrm{R}$ & & & & $\mathrm{R}$ & & VR \\
\hline & STZF3 & VR & & U & $\mathrm{R}$ & VR & & & $\mathrm{R}$ & $\mathrm{R}$ & \\
\hline & STZF4 & $\mathrm{R}$ & & C & C & $\mathrm{R}$ & & $\mathrm{R}$ & C & & \\
\hline \multirow[t]{7}{*}{ STZA } & STZA1 & & & & & & & & C & $\mathrm{R}$ & \\
\hline & STZA2 & u & & & VR & & & & C & U & \\
\hline & STZA3 & & & & & & & & $\mathrm{R}$ & & \\
\hline & STZA4 & $\mathrm{R}$ & & & & & & & C & $\mathrm{R}$ & \\
\hline & STZA5 & U & & & & & & & C & $\mathrm{R}$ & \\
\hline & STZA6 & $\mathrm{R}$ & & & & & & & U & $\mathrm{R}$ & \\
\hline & STZA7 & & $\mathrm{R}$ & & & & & & $\mathrm{R}$ & & \\
\hline
\end{tabular}

rounded pumice lenses, with a total thickness of $\sim 3$ $\mathrm{m}$, separated from the underlying deposits by a sharp surface. These sediments yield Posidonia oceanica and ostreid remains. In the Tunnel Section the marine sands abruptly pass upward, through an angular unconformity, to coarse grained sands and stratified layers containing pumices and rounded lava pebbles, whereas in the La Starza cliff they are upward confined by an erosional surface followed by pyroclastic deposits. A sequence mainly composed of volcanic deposits caps the succession. Its lower part contains coarse ash beds and pumice lenses with cross-lamination and sandwave structures, passing to plane-parallel ash layers. Pyroclastic deposits, correlated with volcanic events (Figure 2), are separated by erosional unconformities or thin paleosols. In the Tunnel Section laminated reworked sands occur between the Agnano-Monte Spina and Averno-Solfatara deposits. They locally show asymmetric ripples

TABLES 2-7 are supplied as spread sheets in one zipped file online. https://palaeo-electronica.org/content/2018/499835/2344-la-starza-forams-and-ostracods-tables

TABLE 2. Benthic foraminifer absolute abundance (I).

TABLE 3. Benthic foraminifer relative abundance (RA,\%).

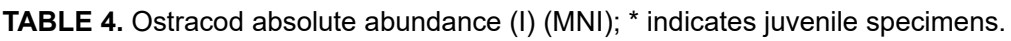

TABLE 5. Ostracod relative abundance (RA,\%) (MNI).

TABLE 6. Ostracod absolute abundance (I) (TNV).

TABLE 7. Ostracod relative abundance (RA,\%) (TNV). 
TABLE 8. Allochthonous ostracod taxa occurrences.

\begin{tabular}{|c|c|c|c|c|c|c|c|c|c|c|c|c|c|c|c|c|}
\hline \multirow{2}{*}{$\begin{array}{l}\text { sections } \\
\text { samples }\end{array}$} & \multicolumn{15}{|c|}{ STZC } & \multirow{2}{*}{$\begin{array}{l}\text { STZF } \\
\stackrel{+}{N}\end{array}$} \\
\hline & 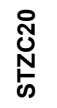 & 突 & 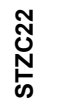 & 胥 & 胥 & 岕 & 胥 & 恿 & 总 & 胥 & 囹 & $\frac{\bar{S}}{\stackrel{5}{N}}$ & 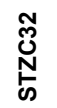 & 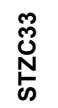 & 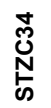 & \\
\hline Candona neglecta Sars, 1887 & & & • & & & & & & & • & & & & & & \\
\hline Candonidae & & & & & & & & & $\cdot$ & & & & & & & \\
\hline Cyclocypris sp. & & & & • & & & & & & & & & & & & \\
\hline Cypria sp. & & & & - & & & & & & & & & & & & \\
\hline Cyprideis torosa (Jones, 1850) & & & & & & & & • & • & • & • & & • & • & • & • \\
\hline Cypridopsis sp. & & & & & & & & & & • & & & & & & \\
\hline Cypris pubera O.F. Müller, 1776 & & & & & & & & & - & • & • & • & & • & & \\
\hline Heterocypris sp. & & & & & & & & & - & & & & & & & \\
\hline Mixtacandona sp. & & & • & & & & & & & & & & & & & \\
\hline Pseudocandona sarsi (Hartwig, 1899) & & & & & & & & & & • & & & & & & \\
\hline
\end{tabular}

TABLE 9. Description and references of assemblage features.

\begin{tabular}{|c|c|c|}
\hline Assemblage feature & Description & References \\
\hline Absolute Abundance (I) & Individuals/100 grams of dried sediment & \\
\hline Relative Abundance (RA) & Species percentage & \\
\hline Dominance (D) & Simpson index of dominance & $\begin{array}{l}\text { Hammer and Harper 2006, Hammer 1999- } \\
2016\end{array}$ \\
\hline Equitability (J) & Shannon diversity divided by the logarithm of number of taxa & $\begin{array}{l}\text { Hammer and Harper 2006, Hammer 1999- } \\
2016\end{array}$ \\
\hline Shannon H' (H’) & Shannon-Wiener Diversity Index (entropy) & $\begin{array}{l}\text { Hammer and Harper 2006, Hammer 1999- } \\
2016 .\end{array}$ \\
\hline Taxa S (S) & Number of species (Species Richness or Simple Diversity) & \\
\hline$A-E$ Index $(A E)$ & $\begin{array}{l}\text { Ammonia-Elphidium Foraminiferal Index (Aubignyna perlucida has been } \\
\text { included in Ammonia) }\end{array}$ & $\begin{array}{l}\text { Sen Gupta et al. 1996; Sen Gupta and } \\
\text { Platon, } 2006\end{array}$ \\
\hline F-O Ratio (FO) & Foraminifer individuals/Ostracod individuals & \\
\hline CFRA & $\begin{array}{l}\text { Circalittoral Foraminifer Relative Abundance: sum of relative abundance of } \\
\text { benthic foraminifer species showing preference for circalittoral waters, with a } \\
\text { relative abundance }>3 \% \text { at least in one sample (Bulimina aculeata, } B \text {. } \\
\text { marginata, Cassidulina carinata, Nonionella turgida and Reussella spinulosa) }\end{array}$ & \\
\hline CORA & $\begin{array}{l}\text { Circalittoral Ostracod Relative Abundance: sum of relative abundance of } \\
\text { ostracod species showing preference for circalittoral waters, with a relative } \\
\text { abundance }>3 \% \text { at least in one sample (Costa edwardsii, Cytheridea } \\
\text { neapolitana, Rectobuntonia subulata and Semicytherura ruggierii) }\end{array}$ & \\
\hline TFRA & $\begin{array}{l}\text { Tolerant Foraminifer Relative Abundance: sum of relative abundance of } \\
\text { benthic foraminifer showing tolerance to stressed and/or low-oxygen } \\
\text { conditions, with a relative abundance }>3 \% \text { at least in one sample (Ammonia } \\
\text { aberdoveyensis lobate form, } A \text {. beccarii, } A \text {. falsobeccarii, Amphicoryna } \\
\text { scalaris, Aubignyna perlucida, Bolivina lowmani, B. pseudoplicata, B. } \\
\text { variabilis, Brizalina spathulata, Bulimina aculeata, B. elongata, B. marginata, } \\
\text { Cassidulina carinata, Cornuspira involvens, Elphidium poeyanum DS form, E. } \\
\text { pulvereum, E. incertum, Epistominella vitrea, Fursenkoina subacuta, } \\
\text { Globocassidulina subglobosa, Haynesina depressula, H. germanica, Nonion } \\
\text { fabum, Nonionella turgida, Rectuvigerina phlegeri, Valvulineria complanata). }\end{array}$ & \\
\hline
\end{tabular}

and are covered, through an unconformable surface, by coarse sands showing tabular cross lamination, correlated with a discontinuous humified dark grey sandy layer, with a maximum thickness of $30 \mathrm{~cm}$, outcropping in the La Starza cliff (Section A). These levels can be assigned to the Pozzuoli unit.
Fifty-four samples resulted fossiliferous and 53 barren. Sediments of the Tunnel Section and of the sections $A$ and $D$ are very poor or completely devoid of fossil remains. Rich and well diversified assemblages were found mainly in Section $\mathrm{C}$ and are retained for statistical analyses thereof. Fossil content consists of calcareous assemblages, 
TABLE 10. Benthic foraminifer assemblage indices.

\begin{tabular}{|c|c|c|c|c|c|c|c|c|c|}
\hline Sections & Samples & 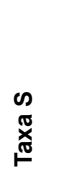 & $\begin{array}{l}\bar{\Xi} \\
\stackrel{0}{0} \\
\frac{\pi}{0} \\
\frac{\pi}{0} \\
\frac{0}{\alpha}\end{array}$ & 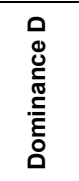 & 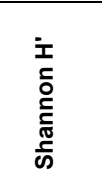 & 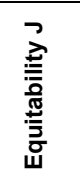 & 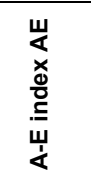 & 选 & 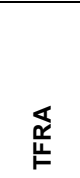 \\
\hline \multirow[t]{22}{*}{ STZC } & STZC 7 & 1 & 1 & - & - & - & - & - & - \\
\hline & STZC 13 & 19 & 1888 & 0.12 & 2.36 & 0.80 & 66.67 & 5.08 & 39.83 \\
\hline & STZC 15 & 30 & 436 & 0.09 & 2.72 & 0.80 & 18.75 & 22.02 & 39.45 \\
\hline & STZC 16 & 12 & 124 & 0.13 & 2.22 & 0.89 & 23.08 & 0.00 & 32.26 \\
\hline & STZC 17 & 18 & 164 & 0.08 & 2.72 & 0.94 & 32.26 & 0.00 & 31.71 \\
\hline & STZC 18 & 41 & 30144 & 0.07 & 3.02 & 0.81 & 35.92 & 25.69 & 60.93 \\
\hline & STZC 19 & 36 & 10848 & 0.06 & 3.02 & 0.84 & 47.18 & 25.66 & 46.90 \\
\hline & STZC 20 & 38 & 16672 & 0.10 & 2.72 & 0.75 & 18.12 & 23.99 & 47.60 \\
\hline & STZC 21 & 30 & 10944 & 0.11 & 2.58 & 0.76 & 15.34 & 26.61 & 54.39 \\
\hline & STZC 22 & 30 & 4960 & 0.10 & 2.63 & 0.77 & 16.11 & 31.29 & 52.58 \\
\hline & STZC 23 & 30 & 6496 & 0.08 & 2.77 & 0.81 & 21.10 & 21.67 & 52.22 \\
\hline & STZC 24 & 36 & 4864 & 0.10 & 2.77 & 0.77 & 25.32 & 24.34 & 53.29 \\
\hline & STZC 25 & 32 & 5328 & 0.09 & 2.84 & 0.82 & 29.57 & 36.94 & 54.05 \\
\hline & STZC 26 & 37 & 4400 & 0.08 & 2.93 & 0.81 & 25.27 & 32.00 & 54.55 \\
\hline & STZC 27 & 33 & 688 & 0.07 & 3.04 & 0.87 & 19.30 & 22.09 & 54.07 \\
\hline & STZC 28 & 44 & 9472 & 0.06 & 3.21 & 0.85 & 35.29 & 22.97 & 49.66 \\
\hline & STZC 29 & 44 & 9736 & 0.06 & 3.12 & 0.82 & 39.08 & 22.93 & 49.73 \\
\hline & STZC 30 & 38 & 7840 & 0.05 & 3.17 & 0.87 & 46.03 & 17.55 & 38.37 \\
\hline & STZC 31 & 39 & 11968 & 0.05 & 3.27 & 0.89 & 24.42 & 20.86 & 47.06 \\
\hline & STZC 32 & 31 & 390 & 0.06 & 3.03 & 0.88 & 30.34 & 16.41 & 32.82 \\
\hline & STZC 33 & 44 & 15040 & 0.05 & 3.29 & 0.87 & 28.45 & 24.04 & 48.72 \\
\hline & STZC 34 & 48 & 22336 & 0.04 & 3.43 & 0.89 & 9.71 & 25.50 & 48.14 \\
\hline \multirow[t]{2}{*}{ STZE } & STZE1 & 26 & 5232 & 0.10 & 2.639 & 0.81 & 25.11 & 13.76 & 43.73 \\
\hline & STZE2 & 24 & 2088 & 0.11 & 2.527 & 0.80 & 21.60 & 16.48 & 55.56 \\
\hline \multirow[t]{2}{*}{ STZB } & STZB 5 & 37 & 5024 & 0.08 & 2.91 & 0.81 & 16.77 & 20.70 & 50.64 \\
\hline & STZB 6 & 32 & 10256 & 0.10 & 2.65 & 0.77 & 20.43 & 30.89 & 57.57 \\
\hline \multirow[t]{4}{*}{ STZF } & STZF1 & 31 & 2344 & 0.08 & 2.85 & 0.83 & 29.79 & 19.80 & 49.15 \\
\hline & STZF2 & 7 & 64 & 0.25 & 1.66 & 0.85 & 33.33 & 0.00 & 18.75 \\
\hline & STZF3 & 9 & 104 & 0.13 & 2.11 & 0.96 & 30.00 & 7.69 & 42.31 \\
\hline & STZF4 & 34 & 1164 & 0.06 & 3.08 & 0.87 & 43.93 & 20.27 & 50.86 \\
\hline STZA & STZA2 & 1 & 1 & - & - & - & - & - & - \\
\hline
\end{tabular}

including benthic and planktonic foraminifers, ostracods, mollusc shells (mainly tiny fragments), serpulid tubes and echinoderm spines, and siliceous remains of diatoms, radiolarians and sponge spicules. Foraminifers occur in 31 samples whereas ostracods in 24. The genera Ammonia and Elphidium (foraminifers) and trachyleberid ostracods generally dominate the assemblages.

The general features of micropaleontological assemblages of the sections are as follows.
Tunnel Succession. It includes samples collected in subsections linked to some excavation fronts of the Tunnel. Most of the samples (Tun 1, 3-21, 24$26,28-34,36-38$ ) were barren. The remaining five samples yielded assemblages dominated by siliceous remains. Tun 2, 22, 27 and 35 consisted almost exclusively of sponge spicules. Tun 23 also contained large diatoms. 
TABLE 11. Ostracod (MNI) assemblage indices.

\begin{tabular}{|c|c|c|c|c|c|c|c|c|}
\hline Sections & Samples & Taxa S & Abundance I & Dominance D & Shannon H' & Equitability $\mathrm{J}$ & CORA & FO \\
\hline \multirow[t]{20}{*}{ STZC } & STZC 15 & 1 & 16 & 1 & - & - & - & 27.25 \\
\hline & STZC 16 & 1 & 4 & 1 & - & - & - & 31.00 \\
\hline & STZC 17 & 1 & 1 & 1 & - & - & - & 164.00 \\
\hline & STZC 18 & 5 & 103 & 0.44 & 1.00 & 0.62 & 89.32 & 292.66 \\
\hline & STZC 19 & 13 & 361 & 0.22 & 1.95 & 0.76 & 55.40 & 30.05 \\
\hline & STZC 20 & 17 & 691 & 0.13 & 2.26 & 0.80 & 23.30 & 24.45 \\
\hline & STZC 21 & 15 & 227 & 0.18 & 2.05 & 0.76 & 19.82 & 49.97 \\
\hline & STZC 22 & 12 & 270 & 0.20 & 1.86 & 0.75 & 22.22 & 18.65 \\
\hline & STZC 23 & 21 & 207 & 0.11 & 2.45 & 0.80 & 15.94 & 32.48 \\
\hline & STZC 24 & 14 & 207 & 0.16 & 2.06 & 0.78 & 28.99 & 23.96 \\
\hline & STZC 25 & 22 & 229 & 0.08 & 2.76 & 0.89 & 27.95 & 25.01 \\
\hline & STZC 26 & 16 & 218 & 0.11 & 2.39 & 0.86 & 25.69 & 20.37 \\
\hline & STZC 27 & 28 & 87 & 0.06 & 3.04 & 0.91 & 18.39 & 8.49 \\
\hline & STZC 28 & 27 & 289 & 0.08 & 2.81 & 0.85 & 14.19 & 34.07 \\
\hline & STZC 29 & 24 & 130 & 0.15 & 2.54 & 0.80 & 37.69 & 82.68 \\
\hline & STZC 30 & 22 & 117 & 0.10 & 2.72 & 0.88 & 27.35 & 75.38 \\
\hline & STZC 31 & 31 & 422 & 0.11 & 2.60 & 0.76 & 34.60 & 30.93 \\
\hline & STZC 32 & 27 & 86 & 0.07 & 2.96 & 0.90 & 8.14 & 5.16 \\
\hline & STZC 33 & 26 & 1061 & 0.08 & 2.76 & 0.85 & 24.13 & 14.43 \\
\hline & STZC 34 & 21 & 741 & 0.13 & 2.39 & 0.79 & 45.34 & 31.64 \\
\hline STZE & STZE1 & 5 & 33 & 0.35 & 1.24 & 0.77 & 30.30 & 159.00 \\
\hline \multirow[t]{2}{*}{ STZB } & STZB 5 & 6 & 52 & 0.35 & 1.31 & 0.73 & 15.38 & 96.62 \\
\hline & STZB 6 & 7 & 41 & 0.46 & 1.17 & 0.60 & 80.49 & 250.15 \\
\hline STZF & STZF4 & 4 & 8 & 0.34 & 1.21 & 0.88 & 50.00 & 146.00 \\
\hline
\end{tabular}

Section D. The two layers sampled in the Section D (STZD 1-2) resulted devoid of microfossil remains.

Section C. In the lower part of the section (samples STZC 1-6) microfossil assemblages are not present. The overlying interval displays an alternation of fossiliferous and barren layers (STZC 7-14). The samples STZC 8, STZC 10-12 and STZC 14 are devoid of fossil remains. In the remaining samples the assemblages are generally poor and consist of rare sponge spicules associated with radiolarians (STZC 9) or benthic foraminifers (STZC 7, STZC 13). In the sample STZC 7 foraminifers are represented by a single specimen of Elphidium granosum; the assemblage recorded in the sample STZC 13 consists of 19 species, the most abundant being Ammonia aberdoveyensis rounded form, $A$. aberdoveyensis lobate form, Ammonia falsobeccarii, Elphidium poeyanum FS form (i.e., morph with flush sutures; v. systematic section) and Buccella granulata. RA of the genera Ammonia (50.85\%) and Elphidium (25.42\%) are very high. The A-E index is high (66.67), whereas diversity $\mathrm{H}^{\prime}(2.36)$ and CFRA $(5.08 \%)$ are very low. Ostracod shells have not been recorded in this interval.

In the upper part of the section, that includes all the samples (STZC 15-34) showing the cooccurrence of benthic foraminiferal and ostracod assemblages, abundance and diversity are relatively high. Statistical analyses have been performed on the assemblages pertaining to this interval (see below). Ostracod assemblages display (Figure 3) a discontinuous decrease of dominance, and an increase of diversity $\mathrm{H}^{\prime}$, simple diversity $\mathrm{S}$ and Equitability $\mathrm{J}$, up to the sample STZC $27\left(H^{\prime}=3.04, S=28, D=0.06 ; J=0.91\right.$ both $\mathrm{MNI}$ and TNV). In comparison with the ostracod assemblages, foraminifers generally show higher diversity and lower dominance values. A remarkable peak of circalittoral taxa is recorded in sample 25 (CFRA $=36.94 \%$;

$\operatorname{CORA}(\mathrm{MNI})=27.95 \%$; CORA $(T N V)=51.87 \%)$, whereas very low values occur in the sample 32 (CFRA $=16.41 \%$; 
TABLE 12. Ostracod (TNV) assemblage indices.

\begin{tabular}{|c|c|c|c|c|c|c|c|c|}
\hline Sections & Samples & Taxa S & Abundance I & Dominance D & Shannon H' & Equitability $\mathrm{J}$ & CORA & FO \\
\hline \multirow[t]{20}{*}{ STZC } & STZC 15 & 1 & 42 & 1 & - & - & - & 10.38 \\
\hline & STZC 16 & 1 & 4 & 1 & - & - & - & 31.00 \\
\hline & STZC 17 & 1 & 8 & 1 & - & - & - & 20.50 \\
\hline & STZC 18 & 5 & 240 & 0.43 & 1.07 & 0.67 & 86.67 & 125.60 \\
\hline & STZC 19 & 13 & 1328 & 0.32 & 1.67 & 0.65 & 68.07 & 8.17 \\
\hline & STZC 20 & 17 & 2632 & 0.15 & 2.17 & 0.77 & 30.70 & 6.37 \\
\hline & STZC 21 & 15 & 764 & 0.23 & 1.82 & 0.67 & 40.31 & 14.48 \\
\hline & STZC 22 & 12 & 1008 & 0.20 & 1.86 & 0.75 & 28.57 & 4.96 \\
\hline & STZC 23 & 21 & 945 & 0.14 & 2.34 & 0.77 & 15.66 & 7.06 \\
\hline & STZC 24 & 14 & 720 & 0.19 & 2.03 & 0.77 & 42.78 & 6.79 \\
\hline & STZC 25 & 22 & 964 & 0.20 & 2.24 & 0.73 & 51.87 & 5.72 \\
\hline & STZC 26 & 16 & 672 & 0.15 & 2.17 & 0.78 & 37.50 & 6.67 \\
\hline & STZC 27 & 28 & 332 & 0.06 & 3.04 & 0.91 & 16.27 & 2.53 \\
\hline & STZC 28 & 27 & 1112 & 0.12 & 2.63 & 0.80 & 32.37 & 9.18 \\
\hline & STZC 29 & 24 & 367 & 0.25 & 2.14 & 0.67 & 50.14 & 29.56 \\
\hline & STZC 30 & 22 & 450 & 0.23 & 2.18 & 0.70 & 46.22 & 18.15 \\
\hline & STZC 31 & 31 & 1984 & 0.18 & 2.42 & 0.70 & 46.37 & 6.53 \\
\hline & STZC 32 & 27 & 222 & 0.08 & 2.82 & 0.86 & 13.51 & 2.48 \\
\hline & STZC 33 & 26 & 4544 & 0.13 & 2.48 & 0.76 & 46.83 & 3.49 \\
\hline & STZC 34 & 21 & 2336 & 0.17 & 2.17 & 0.71 & 50.68 & 9.86 \\
\hline STZE & STZE1 & 5 & 52 & 0.32 & 1.27 & 0.79 & 38.46 & 100.62 \\
\hline \multirow[t]{2}{*}{ STZB } & STZB 5 & 6 & 119 & 0.30 & 1.36 & 0.76 & 16.81 & 42.22 \\
\hline & STZB 6 & 7 & 117 & 0.63 & 0.81 & 0.41 & 88.89 & 87.66 \\
\hline STZF & STZF4 & 4 & 16 & 0.44 & 1.07 & 0.77 & 62.50 & 72.75 \\
\hline
\end{tabular}

$\operatorname{CORA}(\mathrm{MNI})=8.14 \% ; \operatorname{CORA}(\mathrm{TNV})=13.51 \%)$. In the upper part of this interval no clear indices trend is evident. The samples STZC 18-34 were the most reliable for paleoecological interpretation (Figure $3)$. In all the samples are present echinoderm spines; in the main part of the samples sponge spicules, planktonic foraminifers, molluscs, radiolarians, diatoms and serpulids are associated in decreasing order of frequency.

The uppermost sample of the Section C, STZC 35, yielded exclusively common sponge spicules.

Section E. The lowermost sample (STZE 1) yielded siliceous and calcareous remains, including foraminifers, ostracods, sponge spicules, bryozoan and mollusc remains, echinoderm spines. Middle abundance and diversity foraminiferal assemblage and low abundance and diversity ostracod assemblage are recorded. The foraminiferal species E. granosum, Elphidium crispum, Elphidium excavatum, A. aberdoveyensis lobate form and the ostracods Costa edwardsii and Semi- cytherura incongruens dominate the assemblage. Diversity indices are low for foraminiferal and very low for ostracod assemblages; ostracod D and FO are very high, CFRA low.

In the sample STZE 2 foraminifers, sponge spicules, echinoderm spines occur. The foraminiferal assemblage, characterized by low $\mathrm{H}^{\prime}$, low CFRA and high TFRA, is dominated by E. granosum, Nonionella turgida, E. poeyanum DS form, $A$. aberdoveyensis lobate form. Ostracods are not present.

Assemblages of the samples STZE 3-5 consist mostly of siliceous sponge spicules. Neither ostracod nor foraminiferal remains occur.

Section B. The sample STZB 1 is devoid of fossil remains, whereas in the samples STZB 2-4 minute siliceous sponge spicules occur. Samples STZB 5 and STZB 6 yielded siliceous and calcareous remains, including foraminifers, ostracods, diatoms, radiolarians, sponge spicules and echinoderm spines. Benthic foraminiferal assemblages show middle abundance and diversity values; 


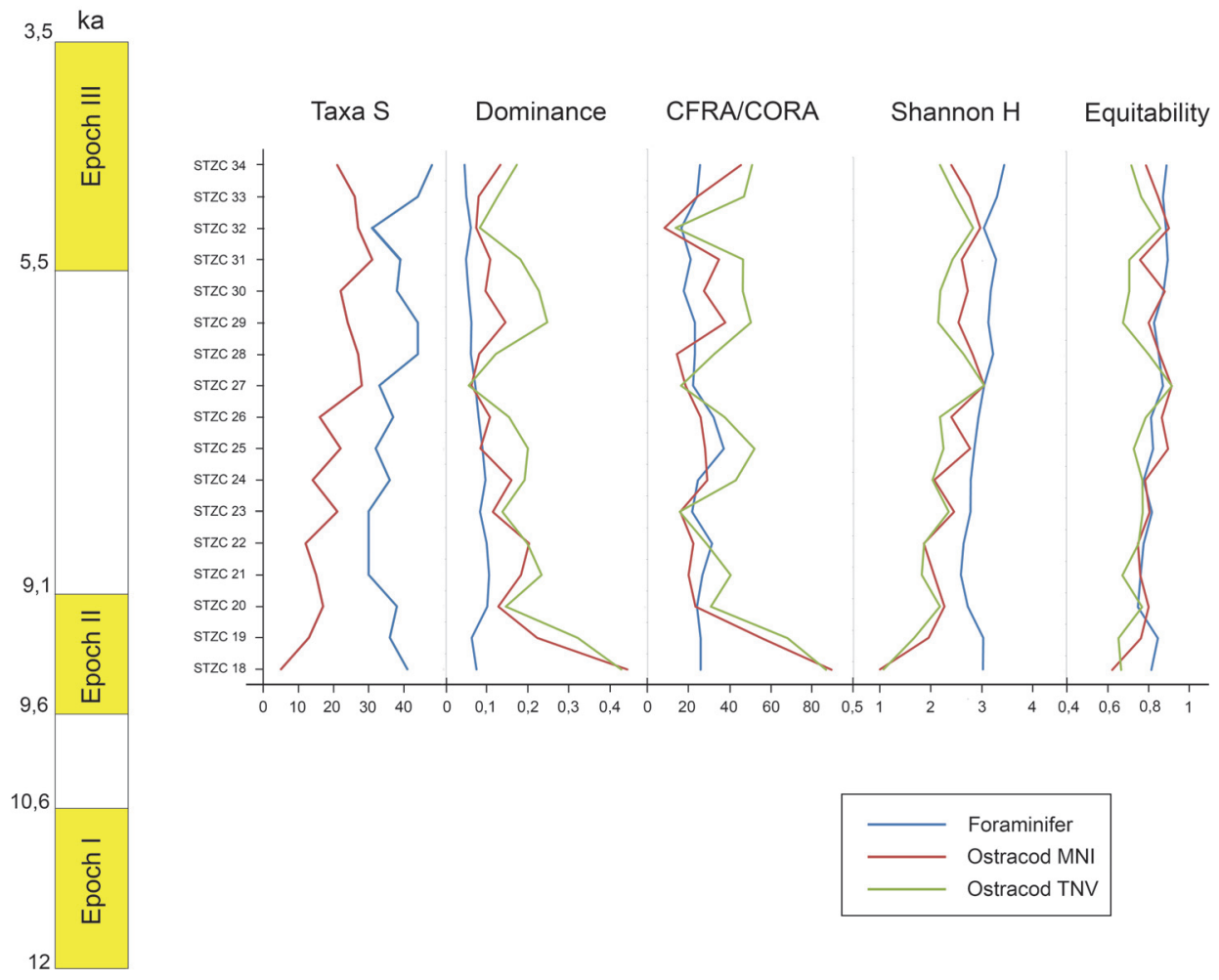

FIGURE 3. Benthic foraminiferal and ostracod assemblage trends in Section C (samples STZC 18 - STZC 34). See text and Table 9 for details.

ostracod assemblages are characterized by high dominance and low diversity/abundance values. FO values are very high $(\mathrm{MNI}=96.62-250.15$; $\mathrm{TNV}=42.22-87.66)$.

The most abundant species are the foraminifer N. turgida (14.65-18.88\%), E. granosum $(12.95-15.92 \%)$, E. poeyanum DS form (7.96$11.7 \%)$ and $A$. aberdoveyensis lobate form (8.28$9.67 \%$ ); ostracod assemblages are dominated by C. edwardsi $(\mathrm{MNI}=15.38-65.85 \%$; TNV $=16.81$ $78.63 \%$ ) and $\mathrm{S}$. incongruens (MNI $=4.88-53.85 \%$; TNV $=2.56-42.86 \%$ ). CFRA, CORA and TFRA values are moderately high. The assemblages of the uppermost part of the section (sample STZB 7-10) consist almost exclusively of siliceous remains (sponge spicules and radiolarians).

Section F. The sample STZF 1, collected at the base of the section, yielded siliceous and calcareous microfossil remains, with sponge spicules, foraminifers and echinoderm spines. Foraminiferal assemblage dominated by $N$. turgida, E. crispum, $A$. aberdoveyensis lobate form and E. poeyanum DS form, shows middle abundance and diversity, moderately low CFRA and high TFRA. Ostracods are not present. The benthic foraminiferal assemblages of the samples STZF 2-3 display low abun- dance and diversity, high dominance and very low CFRA (0-7.69\%). Siliceous sponge spicules and echinoderm spines are present whereas ostracods lack. The uppermost sample (STZF 4) of the section $F$ yielded both benthic foraminiferal and ostracod assemblages. Ostracod assemblage is poor, with high CORA, and $\mathrm{F}-\mathrm{O}$ ratio is very high. CFRA reaches the maximum value of the Section $F(20.27 \%)$.

Section A. In the samples STZA 1-7 siliceous remains (diatoms, sponge spicules and radiolarians) dominate largely the assemblages, whereas the sediments of the upper part of the section (STZA 8-13) are barren.

\section{Statistical Analysis}

The samples pertaining to the middle-upper part of the Section C (STZC 15-34) are characterized by the presence of both benthic foraminifer and ostracod remains. Cluster analysis (Bray-Curtis similarity coefficient) was performed on foraminiferal and ostracod (both $\mathrm{MNI}$ and TNV) assemblages (Figures 4-6). Results, used for paleoenvironmental reconstruction (Figure 7), are slightly different for benthic foraminifer and ostracod analysis. 


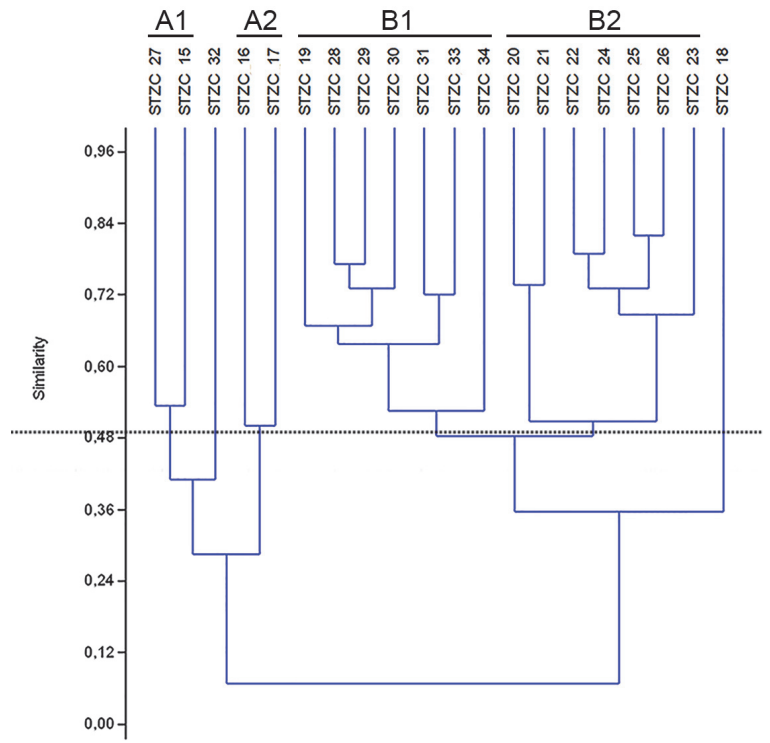

FIGURE 4. Dendrogram based on cluster analyses of benthic foraminifer abundance (I) data.

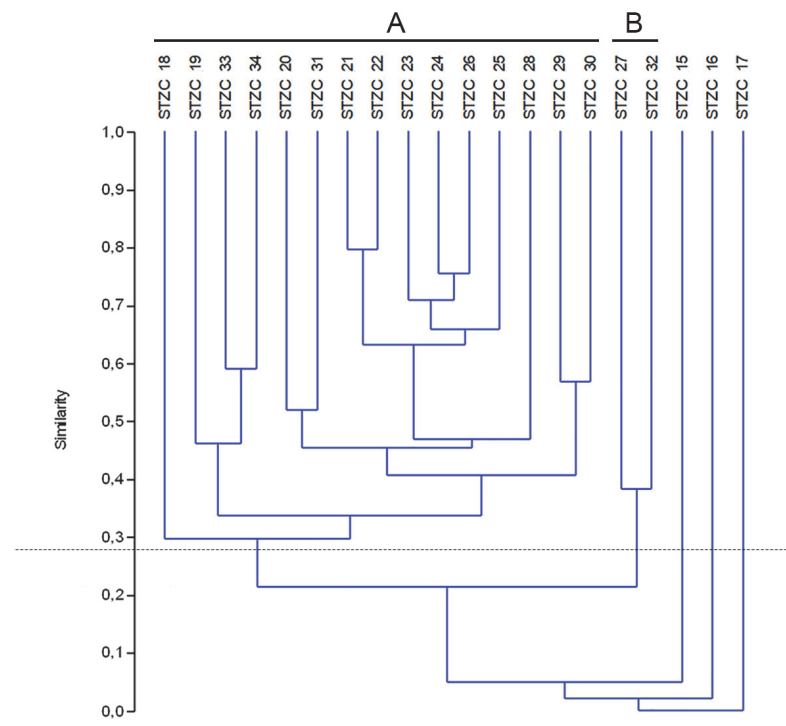

FIGURE 5. Dendrogram based on cluster analyses of ostracod abundance (I) data (MNI).

Foraminifers. The foraminifer dendrogram (Figure 4) displays two main clusters, the first $(A)$ including STZC 15-17, STZC 27 and STZC 32, and the second $(B)$ all the remaining assemblages.

Cluster A. The five assemblages of the Cluster A are characterized by low abundances (I=124-688). It includes two subclusters: A1 (Samples STZC 15, 27 ) and A2 (STZC 16, 17); STZC 32 is individually discriminated. Subcluster A1 consists of the samples with high CFRA (22.02\%-22.09\%) and characterized by high abundances of Asterigerinata

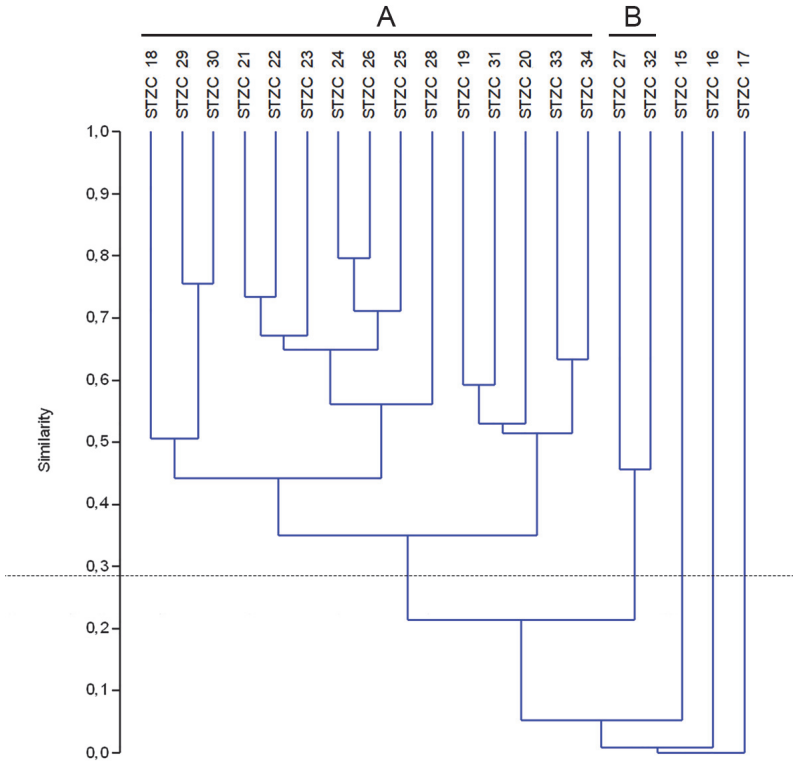

FIGURE 6. Dendrogram based on cluster analyses of ostracod abundance (I) data (TNV).

adriatica (5.23\%-15.14\%) and N. turgida (16.06\%$18.02 \%)$. A2 shows low simple diversity and abundance assemblages $(S=12-18 ; \quad I=124-164)$. The sample 32 displays the lowest dominance $(0.06)$ and highest RA of $B$. granulata (12.1\%) and A-E index (30.34).

Cluster B. The fifteen assemblages of the Cluster $B$ are characterized by high abundances $(I=4400-$ 30144). The sample STZC 18 is individually discriminated, showing high abundance-diversity values; TFRA, CFRA and AE are from high to very high. Two subclusters are discernible.

The Subcluster B1 includes the samples STZC 19, STZC 28-31, STZC 33-34. Foraminifer assemblages show high abundance (7840-22336), diversity ( $\mathrm{S}=36-48 ; \quad \mathrm{H}=3.02-3.43)$, equitability $(\mathrm{J}=0.82-0.89)$ and low dominance $(\mathrm{D}=0.04-0.06)$. The most represented species are $N$. turgida (10.16-16.55\%), Reussella spinulosa (3.19$10.03 \%)$, Haynesina depressula $(2.77-8.29 \%)$ and B. granulata (2.86-8.67\%). Subcluster B2 consists of samples STZC 20-26. Foraminifer abundance and diversity show moderately low values; dominance is high $(\mathrm{D}=0.08-0.11)$, FO low (MNI=18.6549.97; TNV=4.96-14.48). Elphidium species show high percentages in all the samples (21.0944.74\%) and the Ammonia-Elphidium index is low, ranging from 14.04 to 31.19 . The commonest foraminifer species are $N$. turgida (6.90-21.92\%), Bulimina elongata (6.31-10.34\%), E. granosum $(6.31-21.50 \%), A$. aberdoveyensis lobate form 


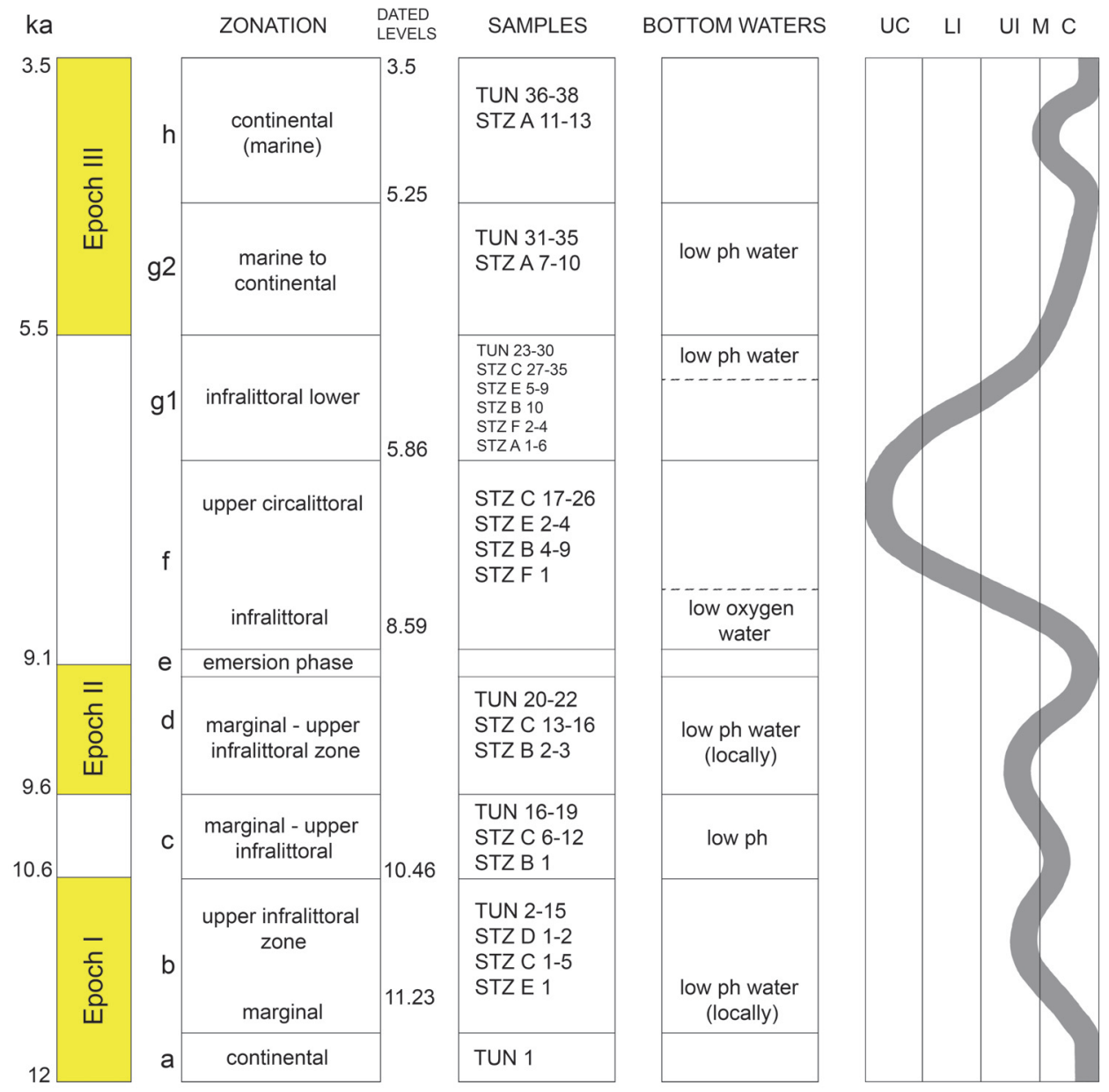

FIGURE 7. Paleoecological events through the La Starza succession and paleobathymetry trends. UC: upper circalittoral; LI: lower infralittoral; UI: upper infralittoral; M: marginal; C: continental.

(5.67-11.51\%), E. poeyanum DS form (5.41$16.96 \%)$ and $R$. spinulosa (5.26-11.94\%).

Ostracods. The ostracod dendrograms (MNI and TNV; respectively Figure 5 and Figure 6 ) are similar. The samples STZC 15, 16 and 17 are individually discriminated. In all these samples ostracods are represented by a single species. Two clusters have been recognized. The Cluster A consists of the samples STZC 18-26, STZC 28-31, STZC 3334. Ostracod diversity indices and abundance, as well as $\mathrm{FO}$, display a wide range $(S=5-31$; $\mathrm{I}(\mathrm{MNI})=103-1061 ; \mathrm{I}(\mathrm{TNV})=240-4544 ; \mathrm{FO}(\mathrm{MNI})=$ 14.43-292.66;

$\mathrm{FO}(\mathrm{TNV})=3.49-125.6$; $\operatorname{CORA}(\mathrm{MNI})=14.19 \%-89.32 \%$; $\quad \operatorname{CORA}(\mathrm{TNV})=$ $15.66 \%-86.67 \%)$. Ostracod assemblages are characterized by C. edwardsi (RA(MNI) $=7.54 \%$ $58.25 \%$; $\quad \operatorname{RA}(\mathrm{TNV})=13.54 \%-58.33 \%), \quad$ Cistacythereis turbida $\quad(\mathrm{RA}(\mathrm{MNI})=4.32 \%-19.32 \%$; $\mathrm{RA}(\mathrm{TNV})=2.05 \%-13.10 \%)$, Carinocythereis whitei $(\mathrm{RA}(\mathrm{MNI})=3.79 \%-34.07 \% ; \quad \mathrm{RA}(\mathrm{TNV})=3.01 \%$ -
$29.76 \%$ ) and Pseudopsammocythere reniformis $(\mathrm{RA}(\mathrm{MNI})=0.85 \%-15.46 \% ; \quad \mathrm{RA}(\mathrm{TNV})=0.68 \%-$ $14.29 \%)$.

Cluster B includes the samples STZC 27 and STZC 32. Their assemblages are characterized by low abundance $(I(M N I)=86-87 ; \mathrm{I}(\mathrm{TNV})=222-332)$, high diversity (S: 27-28; $\mathrm{H}^{\prime}(\mathrm{MNI})=2.96-3.04$; $\left.\mathrm{H}^{\prime}(\mathrm{TNV})=2.82-3.04\right)$, low CORA $\quad(\mathrm{MNI}=8.14 \%-$ $18.39 \%$; $\mathrm{TNV}=13.51-16.27 \%)$ and $\mathrm{FO}(\mathrm{MNI}=5.16-$ 8.49; TNV=2.48-2.53). Loxoconcha ovulata is well represented $\quad(\mathrm{RA}(\mathrm{MNI})=4.60 \quad-18.60 \%$; $\mathrm{RA}(\mathrm{TNV})=6.63 \%-17.12 \%)$.

\section{NOTES ON TAXONOMY AND ECOLOGY}

Order FORAMINIFERIDA von Eichwald, 1830

Suborder MILIOLINA Delage and Herouard, 1896

Family CORNUSPIRIDAE Schultze, 1854

Subfamily CORNUSPIRINAE Schultze, 1854 Genus CORNUSPIRA Schultze, 1854 


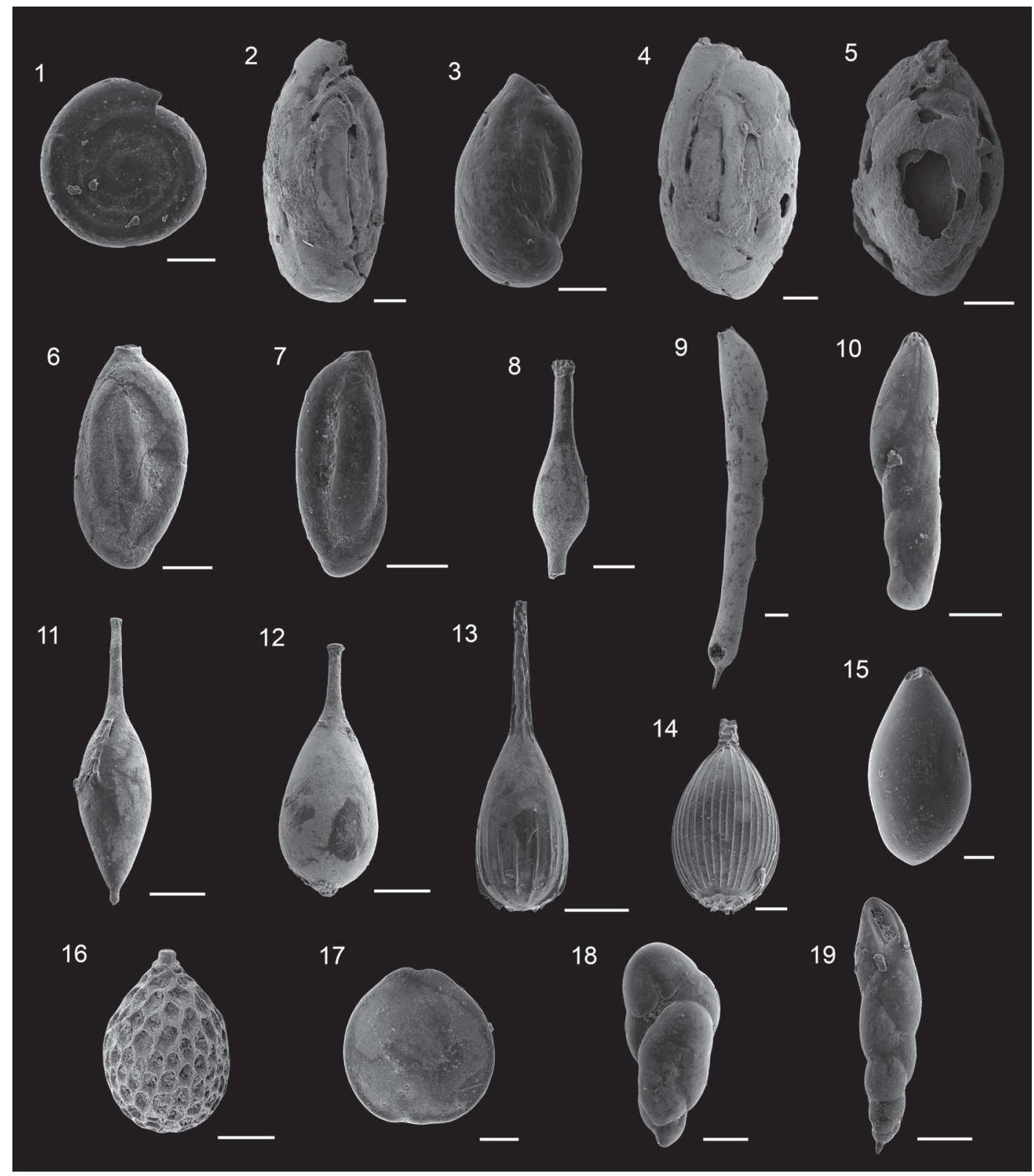

FIGURE 8. 1 Cornuspira involvens (Reuss, 1850), side view, sample STZC 21, ABMC 2016/005; 2 Adelosina longirostra (d'Orbigny, 1826), four chamber side, sample STZC 32, ABMC 2016/046; 3 Quinqueloculina parvula Schlumberger, 1894, four chamber side, sample STZC 21, ABMC 2016/040; 4 Quinqueloculina seminulum (Linnaeus, 1758), four chamber side, sample STZC 32, ABMC 2016/007; 5 Triloculina trigonula (Lamarck, 1804), peripheral view, sample STZC 32, ABMC 2016/079; 6 Sigmoilinita distorta (Phleger and Parker, 1951), side view, sample STZC 28, ABMC 2016/080; 7 Sigmoilinita distorta (Phleger and Parker, 1951), side view, sample STZC 33, ABMC 2017/004; 8 Grigelis guttiferus (d'Orbigny, 1846), lateral view, sample STZC 13, ABMC 2017/003; 9 Laevidentalina communis (d'Orbigny, 1826), lateral view, sample STZC 34, ABMC 2016/042; 10 Marginulina similis d'Orbigny, 1846, side view, sample STZC 21, ABMC 2016/026; 11 Hyalinonetrion clavatum (d'Orbigny, 1846), lateral view, sample STZC 23, ABMC 2016/084; 12 Reussoolina laevis (Montagu, 1803), lateral view, sample STZC 24, ABMC 2016/087; 13 Lagena semistriata Williamson, 1848, lateral view, sample STZC 28, ABMC 2016/023; 14 Lagena striata (d'Orbigny, 1839), lateral view, sample STZC 33, ABMC 2016/008; 15 Globulina minuta (Roemer, 1838), side view, sample STZC 25, ABMC 2016/073; 16 Favulina hexagona (Williamson, 1848), lateral view, sample STZC 13, ABMC 2016/059; 17 Fissurina nummiformis (Buchner, 1940), lateral view, sample STZC 27, ABMC 2016/039; 18 Robertina translucens Cushman and Parker, 1936, lateral view, sample STZC 20, ABMC 2016/088; 19 Stainforthia complanata (Egger, 1893), lateral view, sample STZC 26, ABMC 2016/003; Scale bar 1, 3, 14, 15, 17 - $50 \mu \mathrm{m} ; 2$, 4-13, 16, 18, 19 - $100 \mu \mathrm{m}$. 
Cornuspira involvens (Reuss, 1850)

Figure 8.1

1850a Operculina involvens Reuss: p. 370, pl. 46, fig. 20.

1988 Cyclogyra involvens (Reuss); Amore, Barra, Ciampo, Ruggiero Taddei, Russo and Sgarrella, p. 974.

1990 Cyclogyra involvens (Reuss); Amore, Barra, Ciampo, Ruggiero Taddei, Russo and Sgarrella, p. 480.

2012 Cornuspira involvens (Reuss); Milker and Schmiedl, p. 44, fig. 12.1.

Distribution and remarks. Rare specimens of this opportunistic, eurybathic, low-oxygen tolerant species (Sen Gupta et al., 2009a, b) have been recorded in the sample STZC $21(R A=0.29 \%)$.

Family SPIROLOCULINIDAE Wiesner, 1920

Genus ADELOSINA d'Orbigny, 1826

Adelosina longirostra (d'Orbigny, 1826)

Figure 8.2

1826 Quinqueloculina longirostra d'Orbigny: p. 303, n. 46.

1846 Quinqueloculina longirostra d'Orbigny; d'Orbigny, p. 291, pl. 18, figs. 25-27.

1979 Quinqueloculina longirostra d'Orbigny; Hageman, p. 104, pl. 9, figs. 3-4.

1988 Quinqueloculina longirostra d'Orbigny; Amore, Barra, Ciampo, Ruggiero Taddei, Russo and Sgarrella, p. 974.

1990 Quinqueloculina longirostra d'Orbigny; Amore, Barra, Ciampo, Ruggiero Taddei, Russo and Sgarrella, p. 480.

2012 Adelosina longirostra (d'Orbigny); Milker and Schmiedl, p. 48, figs. 12.20-21.

Distribution and remarks. The species is common in the infralittoral and upper circalittoral zone of the Mediterranean (Sgarrella and Moncharmont, 1993). A certain morphological variability has been figured by Hageman (1979).

Very rare at La Starza; few tests are present in the sample STZC $32(R A=0.51 \%)$. In the sample STZA 2 the assemblage consists of a single specimen of $A$. longirostra.

Family HAUERINIDAE Schwager, 1876

Subfamily HAUERININAE Schwager, 1876

Genus QUINQUELOCULINA d'Orbigny, 1826

Quinqueloculina parvula Schlumberger, 1894 Figure 8.3

1894 Quinqueloculina parvula Schlumberger: p. 255, text-fig. 1, pl. 3, figs. 8-9.

1988 Quinqueloculina parvula Schlumberger; Amore, Barra, Ciampo, Ruggiero Taddei, Russo and Sgarrella, p. 974.
1990 Quinqueloculina parvula Schlumberger; Amore, Barra, Ciampo, Ruggiero Taddei, Russo and Sgarrella, p. 480.

2012 Quinqueloculina parvula Schlumberger; Milker and Schmiedl, p. 59, figs. 15.25-27.

Distribution and remarks. An infralittoral - upper circalittoral species (Sgarrella and Moncharmont Zei, 1993) tolerating heavy metal pollution (Frontalini and Coccioni, 2011); rare individuals have been found in two samples of the Section C.

\section{Quinqueloculina pygmaea Reuss, 1850}

1850a Quinqueloculina pygmaea Reuss: p. 384. pl. 50, fig. 3.

1993 Quinqueloculina pygmaea Reuss; Sgarrella and Moncharmont Zei, p. 174, pl. 7, fig. 2.

Distribution and remarks. An eurybathic species (Szarek, 2001; Enge et al., 2012) more frequent in infralittoral - upper circalittoral waters (Sgarrella and Moncharmont Zei, 1993). Few tests of Q. pygmaea occur in two samples of the Section C (STZC 29 and STZC 32).

Quinqueloculina seminulum (Linnaeus, 1758)

Figure 8.4

1758 Serpula seminulum Linnaeus: p. 786.

1988 Quinqueloculina seminulum (Linnaeus); Amore, Barra, Ciampo, Ruggiero Taddei, Russo and Sgarrella, p. 974.

1990 Quinqueloculina seminulum (Linnaeus); Amore, Barra, Ciampo, Ruggiero Taddei, Russo and Sgarrella, p. 480.

2003 Quinqueloculina seminulum (Linnaeus); Murray, p. 17 , figs. 4.11-4.12.

2012 Quinqueloculina seminula (Linnaeus); Milker and Schmiedl, p. 59, figs. 15.30-31.

Distribution and remarks. An opportunistic (Langlet et al., 2014) eurybathic (Szarek, 2001; Enge et al., 2012) species, common in marginal, infralittoral and upper circalittoral zone (Murray, 2006; Sen Gupta et al., 2009b). Rare specimens are present in the samples STZC 30 and STZC 32.

\section{Subfamily MILIOLINELLINAE Vella, 1957 \\ Genus TRILOCULINA d'Orbigny, 1826 \\ Triloculina trigonula (Lamarck, 1804)}

Figure 8.5

1804 Miliolites trigonula Lamarck: p. 351, pl. 17, figs. $4 \mathrm{a}-\mathrm{c}$.

2012 Triloculina trigonula (Lamarck); Debenay, pp. 138, 278.

Distribution and remarks. An eurybathic species (Szarek, 2001; Sen Gupta et al., 2009b), preferring infralittoral and upper circalittoral zone (Oflaz, 2006). Very rare at La Starza, it is present only in the sample STZC 32 with $R A=1.54 \%$. 
Subfamily SIGMOILINITINAE ?uczkowska, 1974 Genus SIGMOILINITA Seiglie, 1965

Sigmoilinita distorta (Phleger and Parker, 1951)

Figure 8.6-7

1951 Sigmoilina distorta Phleger and Parker: p. 8, pl. 4, figs. 3-5.

1988 Sigmoilina distorta Phleger and Parker; Amore, Barra, Ciampo, Ruggiero Taddei, Russo and Sgarrella, p. 974.

1990 Sigmoilina distorta Phleger and Parker; Amore, Barra, Ciampo, Ruggiero Taddei, Russo and Sgarrella, p. 480.

2012 Sigmoilinita distorta (Phleger and Parker); Milker and Schmiedl, p. 69, figs. 18.3-4.

Distribution and remarks. An eurybathic species (Sen Gupta et al., 2009b) uncommon in the infralittoral zone (Sgarrella and Moncharmont, 1993; Aiello, Barra and Parisi, pers. obs.). Rare at La Starza, it is present in two samples of Section C.

Suborder LAGENINA Delage and Herouard, 1896

Family NODOSARIIDAE Ehrenberg, 1838

Subfamily NODOSARIINEA Ehrenberg, 1838

Genus GRIGELIS Mikhalevich, 1981

Grigelis guttiferus (d'Orbigny, 1846)

Figure 8.8

1846 Dentalina guttifera d'Orbigny: p. 49, pl. 2, figs. 11, 13.

1994 Grigelis guttiferus (d'Orbigny); Loeblich and Tappan, p. 64.

2012 Dentalina guttifera d'Orbigny; Milker and Schmiedl, p. 72, figs. 18.13.

Distribution and remarks. The species, generally occurring in bathyal muds (Sgarrella and Moncharmont-Zei, 1993), is very rare at La Starza, being present only in the sample STZC $13(\mathrm{RA}=0.42 \%)$.

Genus LAEVIDENTALINA Loeblich and Tappan, 1986

Laevidentalina communis (d'Orbigny, 1826)

Figure 8.9

1826 Nodosaria (Dentalina) communis d'Orbigny: p. 254, n. 35.

2012 Laevidentalina communis (d'Orbigny); Debenay, pp. 165, 284.

Distribution and remarks. Few specimens of Laevidentalina communis, a species mainly recorded in bathyal environment (Sgarrella and Moncharmont, 1993; Debenay, 2012), occur in the sample STZC 34.

Family VAGINULIDAE Reuss, 1860 Subfamily LENTICULININAE Chapman, Parr and Collins, 1934

Genus NEOLENTICULINA McCulloch, 1977

Neolenticulina peregrina (Schwager, 1866)
1866

Cristellaria peregrina Schwager: p. 245, pl. 7 , fig. 8.

2012 Neolenticulina peregrina (Schwager); Milker and Schmiedl, p. 73, figs. 18.21.

Distribution and remarks. An eurybathic species, mainly circalittoral and bathyal (Szarek, 2001; Sen Gupta et al., 2009b), very rare at La Starza. It is present only in the sample STZC 34.

Subfamily MARGINULININAE Wedekind, 1937

Genus AMPHICORYNA Schlumberger, 1881 Amphicoryna scalaris (Batsch, 1791)

$1791 \quad$ Nautilus (Orthoceras) scalaris Batsch: pp. 1, 4, pl. 2, figs. 4a-b.

1988 Amphicoryna scalaris (Batsch); Amore, Barra, Ciampo, Ruggiero Taddei, Russo and Sgarrella, p. 974.

1990 Amphicoryna scalaris (Batsch); Amore, Barra, Ciampo, Ruggiero Taddei, Russo and Sgarrella, pp. 480, 482.

2012 Amphicoryna scalaris (Batsch); Milker and Schmiedl, p. 73, figs. 18.22-25.

Distribution and remarks. Rare and poorly preserved specimens of this eurybathic (Sgarrella and Moncharmont-Zei, 1993), stress tolerant (Mojtahid et al., 2006) species, have been recorded in two samples (STZC 18 and STZC 34).

Genus MARGINULINA d'Orbigny, 1826 Marginulina similis d'Orbigny, 1846

Figure 8.10

1846 Marginulina similis d'Orbigny, p. 69, pl. 3, figs. 15-16.

1985 Marginulina similis d'Orbigny; Papp and Schmid, p. 37, pl. 21, figs 10-12.

1988 Marginulina glabra d'Orbigny; Amore, Barra, Ciampo, Ruggiero Taddei, Russo and Sgarrella, p. 974.

1990 Marginulina glabra d'Orbigny; Amore, Barra, Ciampo, Ruggiero Taddei, Russo and Sgarrella, p. 482.

Distribution and remarks. A lower circalittoral to middle bathyal species (Sgarrella and Moncharmont Zei, 1993; Szarek, 2001; as M. glabra), present exclusively in the sample STZC 21 (RA $=0.58 \%$ ).

Family LAGENIDAE Reuss, 1862

Genus HYALINONETRION Patterson and Richardson, 1987

Hyalinonetrion clavatum (d'Orbigny, 1846)

Figure 8.11

1846 Oolina clavata d'Orbigny: p. 24, pl. 1, figs. 23.

1940 Lagena clavata (d'Orbigny); Buchner, p. 416, pl. 2, figs. 28-30. 
1988 Lagena clavata (d'Orbigny); Amore, Barra, Ciampo, Ruggiero Taddei, Russo and Sgarrella, p. 974.

1990 Lagena clavata (d'Orbigny); Amore, Barra, Ciampo, Ruggiero Taddei, Russo and Sgarrella, pp. 480, 482.

1998 Hyalinonetrion clavatum (d'Orbigny); Cicha, Rögl, Rupp and Ctyroka, p. 108, pl. 27, fig. 6.

Distribution and remarks. An accessory species, recorded in infralittoral and upper circalittoral environment (Sgarrella and Moncharmont Zei, 1993; Debenay et al., 2001b), present both in Section C and in Section B. RA ranges from $0.16 \%$ to $0.99 \%$.

Genus LAGENA Walker and Jacob, 1798 Lagena semistriata Williamson, 1848

Figure 8.13

1848 Lagena striata (Montagu) var. $ß$, semistriata Williamson: p. 14, pl. 1, figs. 9-10.

1988 Lagena semistriata Williamson; Amore, Barra, Ciampo, Ruggiero Taddei, Russo and Sgarrella, p. 974.

1990 Lagena semistriata Williamson; Amore, Barra, Ciampo, Ruggiero Taddei, Russo and Sgarrella, pp. 480, 482 .

1940 Lagena laevis (Montagu) forma semistriata (Williamson); Buchner, pl. 3, figs. 39-43.

1993 Lagena semistriata Williamson; Sgarrella and Moncharmont Zei, p. 198, pl. 12, fig. 1.

Distribution and remarks. A shelf species (Sgarrella and Moncharmont Zei, 1993; Szarek, 2001), present at La Starza with rare and scattered individuals.

Lagena striata (d’Orbigny, 1839)

Figure 8.14

1839c Oolina striata d'Orbigny: p. 21, pl. 5, fig. 12.

1940 Lagena striata (d'Orbigny); Buchner, p. 424, pl. 4, figs. 54-61.

2012 Lagena striata (d'Orbigny); Milker and Schmiedl, p. 75, fig. 18.33.

Distribution and remarks. This eurybathic species (Szarek et al., 2001; Sen Gupta et al., 2009b) is rare in the La Starza deposits, showing RA values not exceeding $0.66 \%$.

Genus PROCEROLAGENA Puri, 1954

Procerolagena gracilis (Williamson, 1848)

1848 Lagena gracilis Williamson: p. 13, pl. 1, fig. 5.

2009a Procerolagena gracilis (Williamson); Sen Gupta, Lobegeier and Smith, p. 58, pl. 135, figs. 1-6.

Distribution and remarks. A very rare species, recorded in the lower circalittoral and bathyal zone (Sen Gupta, 2009b), present at La Starza only in the sample STZC $28(\mathrm{RA}=0.34 \%)$.
Genus REUSSOOLINA Colom, 1956

Reussoolina laevis (Montagu, 1803)

Figure 8.12

1803 Vermiculum Laeve Montagu: p. 524.

1940 Lagena laevis (Montagu) forma laevis (Montagu); Buchner, pl. 3, figs. 34-36.

1993 Lagena laevis (Montagu); Sgarrella and Moncharmont Zei, p. 198, pl. 11, fig. 14.

1994 Reussoolina laevis d'Orbigny; Loeblich and Tappan, p. 81, pl. 144, figs. 13-14.

Distribution and remarks. An eurybathic (Sgarrella and Moncharmont Zei, 1993; Sen Gupta, 2009b) species, occurring at La Starza with low RA values $(0.16 \%-0.99 \%)$ both in the Section $C$ and in the Section B.

Family POLYMORPHINIDAE d'Orbigny, 1839

Subfamily POLYMORPHININAE d'Orbigny, 1839

Genus GLOBULINA d'Orbigny, 1839

Globulina minuta (Roemer, 1838)

Figure 8.15

1838a Polymorphina minuta Roemer: p. 386, pl. 3, figs. 35a-b.

1930 Globulina minuta (Roemer); Cushman and Ozawa, pp. 83-84, pl. 20, figs. 3-4.

1971 Globulina minuta (Roemer); Gabel, pl. 11, figs. 28-29.

Distribution and remarks. An infralittoral and upper circalittoral species (Sgarrella and Moncharmont, 1993) present with few specimens in section $C$, with $\mathrm{RA}$ ranging from 0.29 to $1.74 \%$.

Family ELLPISOLAGENIDAE Silvestri, 1923 Subfamily OOLININAE Loeblich and Tappan, 1961 Genus FAVULINA Patterson and Richardson, 1987 Favulina hexagona (Williamson, 1848)

Figure 8.16

1848 Entesolenia squamosa (Montagu) var. ? hexagona Williamson: p. 20, pl. 2, fig. 23 pl. 5, fig. 63.

2012 Favulina hexagona (Williamson); Milker and Schmiedl, p. 77, figs. 19.4 .

Distribution and remarks. An eurybathic species (Sen Gupta et al., 2009b) recorded, with few specimens, in two samples of the Section C (STZC 13 and STZC 33).

Subfamily ELLIPSOLAGENINAE Silvestri, 1923 Genus FISSURINA Reuss, 1850

Fissurina nummiformis (Buchner, 1940)

Figure 8.17

1940 Lagena nummiformis Buchner: p. 457, pl. 8, figs. 135-138.

1993 Fissurina nummiformis (Buchner); Sgarrella and Moncharmont-Zei, p. 202. 
Distribution and remarks. A circalittoral - upper bathyal species (Buchner, 1940; Sgarrella and Moncharmont-Zei, 1993), present only in the in sample STZC 27 (RA=0.58\%).

Family GLANDULINIDAE Reuss, 1860

Genus GLANDULINA d'Orbigny, 1839

Glandulina laevigata (d'Orbigny, 1826)

1826 Nodosaria laevigata d'Orbigny: p. 252, pl. 10, figs. 1-3.

1988 Glandulina laevigata (d'Orbigny); Amore, Barra, Ciampo, Ruggiero Taddei, Russo and Sgarrella, p. 974.

1990 Glandulina laevigata (d'Orbigny); Amore, Barra, Ciampo, Ruggiero Taddei, Russo and Sgarrella, p. 480.

2012 Glandulina laevigata (d'Orbigny); Debenay, pp. 164, 296.

Distribution and remarks. An infra-circalittoral (Szarek, 2001; Debenay, 2012), subordinately bathyal (Sgarrella and Moncharmont Zei, 1993) species, rare at La Starza. It is recorded in two samples of the section C (STZC 30 and STZC 34).

Family CERATOBULIMINIDAE Cushman, 1927 Subfamily CERATOBULIMININAE Cushman, 1927 Genus LAMARCKINA Berthelin, 1881 Lamarckina scabra (Brady, 1884)

1884 Pulvinulina oblonga (Williamson) var. scabra Brady: p. 689, pl. 106, fig. 8.

2005 Lamarckina scabra (Brady); Debenay, Millet and Angelidis, pl. 3, figs. 1.24-25.

Distribution and remarks. A shelf species (Szarek, 2001; Sen Gupta et al., 2009b; Debenay, 2012), very rare at La Starza. Few individuals are present only in the sample STZC 34.

Family ROBERTINIDAE Reuss, 1850

Subfamily ALLIATININAE McGowran, 1966

Genus ROBERTINA d'Orbigny, 1846

Robertina translucens Cushman and Parker, 1936

Figure 8.18

1936 Robertina translucens Cushman and Parker: p. 99, pl. 16, figs. 8a-b.

2012 Robertina translucens Cushman and Parker; Milker and Schmiedl, p. 80, figs. 19.17-18.

Distribution and remarks. A circalittoral-abyssal species very rare at depth lesser than $60 \mathrm{~m}$ (Sgarrella and Moncharmont Zei, 1993). It is present at La Starza with low RA $(0.19 \%$ to $0.42 \%)$ in four samples of the Section C.

Suborder ROTALIINA Delage and Herouard, 1896

Family BOLIVINIDAE Glaessner, 1937 Genus BOLIVINA d'Orbigny, 1839
Bolivina catanensis Seguenza, 1862

Figure 9.6

1862 Bolivina catanensis Seguenza: pp. 113, 125, pl. 2, fig. 3.

1988 Bolivina catanensis Seguenza; Amore, Barra, Ciampo, Ruggiero Taddei, Russo and Sgarrella, p. 974.

1990 Bolivina catanensis Seguenza; Amore, Barra, Ciampo, Ruggiero Taddei, Russo and Sgarrella, p. 482.

1993 Bolivina catanensis Seguenza; Sgarrella and Moncharmont-Zei, p. 208, pl. 14, figs. 4-5.

Distribution and remarks. Bolivina catanensis is present in the infralittoral zone, showing its optimum in circalittoral and upper bathyal waters with moderate oxygen depletion (Sgarrella and Moncharmont-Zei, 1993; Stefanelli and Capotondi, 2008). Rare in the La Starza sediments, the species occurs in two samples (STZC 25 and STZC 34) of the Section C.

Bolivina cistina Cushman, 1936

1936 Bolivina cistina Cushman: p. 55, pl. 8, fig. 4.

1990 Bolivina cistina Cushman; Hasegawa, Sprovieri and Poluzzi, pl. 3, figs. 1-2.

2012 Bolivina cistina Cushman; Milker and Schmiedl, p. 80, figs. 19.19-20.

Distribution and remarks. A shelf (Milker and Schmiedl, 2012) species, very rare at La Starza, being present only in the sample STZC 33.

Bolivina lowmani Phleger and Parker, 1951

Figure 9.7

1951 Bolivina lowmani Phleger and Parker: p. 13, pl. 6, figs. 20-21.

1981 Brizalina lowmani (Phleger and Parker); Poag, p. 46, pl. 25, fig. 3; pl. 26, figs. 3a-c.

1988 Bolivina lowmani Phleger and Parker; Amore, Barra, Ciampo, Ruggiero Taddei, Russo and Sgarrella, p. 974.

1990 Bolivina lowmani Phleger and Parker; Amore, Barra, Ciampo, Ruggiero Taddei, Russo and Sgarrella, pp. 480, 482

2009a Bolivina lowmani Phleger and Parker; Sen Gupta, Lobegeier and Smith, p. 67, pl. 20, figs. 1-3.

Distribution and remarks. An eurybathic species (Sen Gupta et al., 2009b), dominant in high organic flux, low-oxygen, stressed environment (Vilela et al., 2004). It occurs in 13 samples of the section $C$ (ranging from $0.96 \%$ to $5.14 \%$ ) and in the samples STZB $5(1.27 \%)$ and STZB $6(0.31 \%)$.

Bolivina pseudoplicata Heron-Allen and Earland, 1930

Figure 9.1 


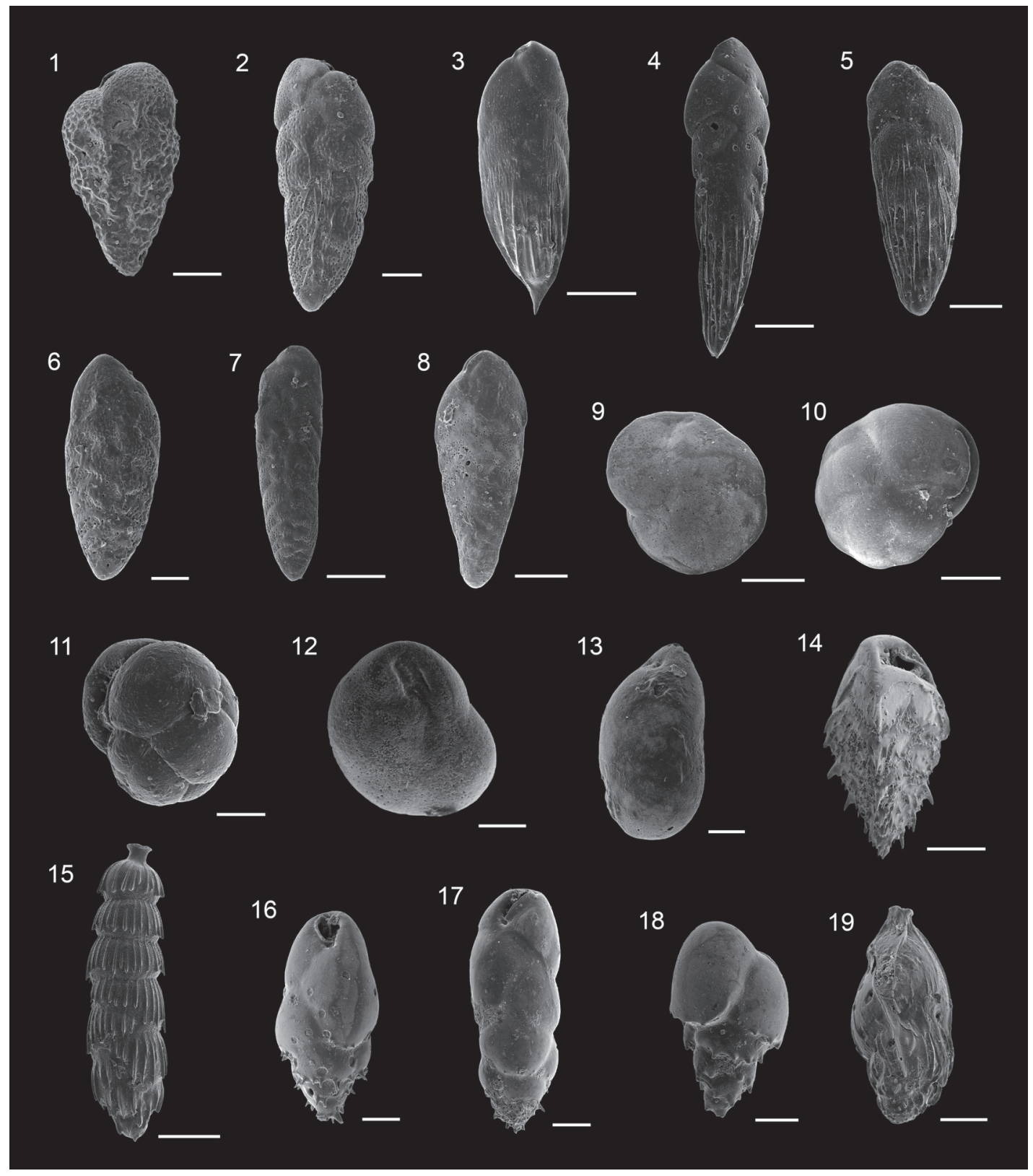

FIGURE 9. 1 Bolivina pseudoplicata Heron-Allen and Earland, 1930, lateral view, sample STZC 18, ABMC 2016/047; 2 Bolivina variabilis (Williamson, 1858), lateral view, sample STZC 18, ABMC 2016/049; 3 Brizalina aenariensis Costa, 1856, lateral view, sample STZC 29 ABMC 2016/081; 4 Brizalina aenariensis Costa, 1856, lateral view, sample STZC 31, ABMC 2017/005; 5 Brizalina striatula Cushman, 1922, lateral view, sample STZB 6, ABMC 2017/007; 6 Bolivina catanensis Seguenza, 1862, lateral view, sample STZC 25, ABMC 2016/074; 7 Bolivina lowmani Phleger and Parker, 1951, lateral view, sample STZC 29, ABMC 2016/033; 8 Brizalina spathulata (Williamson, 1858), lateral view, sample STZC 27, ABMC 2016/063; 9 Cassidulina carinata Silvestri, 1896, side view, sample STZC 21, ABMC 2016/028; 10 Cassidulina carinata Silvestri, 1896, apertural side, sample STZC 31, ABMC 2017/095; 11 Cassidulina obtusa Williamson, 1858, apertural side, sample STZC 19, ABMC 2016/032; 12 Globocassidulina subglobosa (Brady, 1881), apertural side, sample STZC 33, ABMC 2017/088; 13 Evolvocassidulina bradyi (Norman, 1881), lateral view, sample STZC 24, ABMC 2016/037; 14 Reussella spinulosa (Reuss, 1850), lateral view, sample STZC 23, ABMC 2016/085; 15 Rectuvigerina phlegeri Le Calvez, 1959, lateral view, sample STZC 29, ABMC 2016/022; 16 Bulimina aculeata d'Orbigny, 1826, lateral view, sample STZC 20, ABMC 2016/041; 17 Bulimina elongata d'Orbigny, 1846, lateral view, sample STZC 18, ABMC 2016/010; 18 Bulimina marginata d'Orbigny, 1826, lateral view, sample STZC 15, ABMC 2016/020; 19 Trifarina angulosa (Williamson, 1858), lateral view, sample STZC 33, ABMC 2016/004; Scale bar 1, 2, 6, 11-13, 16$19-50 \mu \mathrm{m} ; 3-5,7-10,14,15-100 \mu \mathrm{m}$. 
1930 Bolivina pseudoplicata Heron-Allen and Earland: pp. 81-82, pl. 3, figs. 36-40.

1988 Bolivina pseudoplicata Heron-Allen and Earland; Amore, Barra, Ciampo, Ruggiero Taddei, Russo and Sgarrella, p. 974.

1990 Bolivina pseudoplicata Heron-Allen and Earland; Amore, Barra, Ciampo, Ruggiero Taddei, Russo and Sgarrella, pp. 480, 482.

2003 Bolivina pseudoplicata Heron-Allen and Earland; Murray, p. 19, fig. 5.17.

Distribution and remarks. Bolivina pseudoplicata is an eurybathic, dysoxic tolerant (Murray, 1991; Langlet et al., 2014) species, occurring in the upper part of the Section C and in STZB 6 with rare specimens.

Bolivina variabilis (Williamson, 1858)

Figure 9.2

1858 Textularia variabilis Williamson: p. 76, pl. 6, figs. 162-163.

1988 Bolivina variabilis (Williamson); Amore, Barra, Ciampo, Ruggiero Taddei, Russo and Sgarrella, p. 974.

1990 Bolivina variabilis (Williamson); Amore, Barra, Ciampo, Ruggiero Taddei, Russo and Sgarrella, pp. 480, 482

2012 Bolivina variabilis (Williamson); Milker and Schmiedl, p. 81, figs. 19.25-26.

Distribution and remarks. A shelf species (Sen Gupta et al., 2009b) stress tolerant (Frontalini and Coccioni, 2011) and low-oxygen tolerant (Schmiedl et al., 2003; Kuhnt et al., 2007). It occurs with rare individuals in six samples of the Section $C$ and in the sample STZB 6.

Genus BRIZALINA Costa, 1856

Brizalina aenariensis Costa, 1856

Figure 9.3-4

1856 Brizalina aenariensis Costa: p. 297, pl. 15, fig. 1 a.

1988 Bolivina aenariensis (Costa); Amore, Barra, Ciampo, Ruggiero Taddei, Russo and Sgarrella, p. 974.

1990 Bolivina aenariensis (Costa); Amore, Barra, Ciampo, Ruggiero Taddei, Russo and Sgarrella, pp. 480, 482.

1992 Bolivina aenariensis (Costa); Sgarrella, pp. 317-323, pl. 1, figs. 1-13; pl. 2, figs. 1-11.

1996 Brizalina aenariensis Costa; Revets, p. 9, pl. 4 , figs. 5-8.

Distribution and remarks. The species, occurring in Recent waters from the middle-lower infralittoral to upper bathyal zone (Sgarrella and Moncharmont-Zei, 1993; Frezza and Carboni, 2009) is not frequent at La Starza, with RA ranging from $0.16 \%$ to $0.86 \%$.
Brizalina spathulata (Williamson, 1858)

Figure 9.8

1858 Textularia variabilis var. spathulata Williamson: p. 76, pl. 6, figs. 164-165.

1988 Bolivina spathulata (Williamson); Amore, Barra, Ciampo, Ruggiero Taddei, Russo and Sgarrella, p. 974.

1990 Bolivina spathulata (Williamson); Amore, Barra, Ciampo, Ruggiero Taddei, Russo and Sgarrella, p. 480.

2012 Brizalina spathulata (Williamson); Milker and Schmiedl, p. 82, figs. 20.1-2.

Distribution and remarks. A typical low oxygen tolerant species (Stefanelli, 2004), living in infralittoral waters and recorded in the Section C with rare specimens.

Brizalina striatula (Cushman, 1922)

Figure 9.5

1922 Bolivina striatula Cushman: p. 27, pl. 3, fig. 10.

1988 Bolivina striatula Cushman; Amore, Barra, Ciampo, Ruggiero Taddei, Russo and Sgarrella, p. 974

1990 Bolivina striatula Cushman; Amore, Barra, Ciampo, Ruggiero Taddei, Russo and Sgarrella, p. 482.

2012 Brizalina striatula (Cushman); Milker and Schmiedl, p. 82, fig. 20.3.

Distribution and remarks. A low-oxygen, high organic matter, low-salinity tolerant species, reported mainly from marginal to circalittoral environment, preferring coastal lagoons and estuaries (Eichler et al., 2003; Sen Gupta et al., 2009b; Debenay, 2012). Present at La Starza with generally low RA values $(0.16 \%-6.45 \%)$ in the majority of the fossiliferous samples.

Family CASSIDULINIDAE d'Orbigny, 1839 Subfamily CASSIDULININAE d'Orbigny, 1839

Genus CASSIDULINA d'Orbigny, 1826 Cassidulina carinata Silvestri, 1896

Figure 9.9-10

1896 Cassidulina laevigata d'Orbigny var. carinata Silvestri: p. 104, pl. 2, figs. 10 a-c.

1988 Cassidulina laevigata carinata Silvestri; Amore, Barra, Ciampo, Ruggiero Taddei, Russo and Sgarrella, p. 975.

1990 Cassidulina laevigata carinata Silvestri; Amore, Barra, Ciampo, Ruggiero Taddei, Russo and Sgarrella, pp. 481-482.

2009a Cassidulina carinata Silvestri; Sen Gupta, Lobegeier and Smith, p. 72, pls. 33-34.

Distribution and remarks. Cassidulina carinata is an opportunistic circalittoral-bathyal species that 
tolerates suboxic waters (Jorissen et al., 2007). This species is present at La Starza in the majority of the fossiliferous samples (RA $=0.21 \%-5.53 \%$ ).

\section{Cassidulina obtusa Williamson, 1858}

\section{Figure 9.11}

1858 Cassidulina obtusa Williamson: p. 69, pl. 6, figs. 143-144.

1988 Cassidulina crassa d'Orbigny; Amore, Barra, Ciampo, Ruggiero Taddei, Russo and Sgarrella, p. 975.

1990 Cassidulina crassa d'Orbigny; Amore, Barra, Ciampo, Ruggiero Taddei, Russo and Sgarrella, p. 481.

2009a Cassidulina obtusa Williamson; Sen Gupta, Lobegeier and Smith, pp. 73-74, pl. 36, figs. 1-5.

2012 Cassidulina obtusa Williamson; Milker and Schmiedl, pp. 84-85, figs. 20.7-8.

Distribution and remarks. The species has been frequently reported as Cassidulina crassa d'Orbigny, 1839c (v. Sen Gupta et al., 2009a; Milker and Schmiedl, 2012). This species prefers high oxygen concentrations (De Rijk et al., 2000; Kuhnt et al., 2007, as C. crassa) in the lower circalittoral-bathyal zone (Murray, 2003; Sen Gupta et al., 2009a; Milker and Schmiedl, 2012). Rare individuals have been recorded in four samples of the Section C and in STZB 6.

EVOLVOCASSIDULINA Eade, 1967

Evolvocassidulina bradyi (Norman, 1881)

Figure 9.13

1881 Cassidulina bradyi Norman (in Brady, 1881): p. 59.

1983 Evolvocassidulina bradyi (Norman); Nomura, p. 48 , pl. 4 , figs. $3 a-b$.

2012 Cassidulinoides bradyi (Norman); Milker and Schmiedl, p. 85, fig. 20.9.

Distribution and remarks. Very rare specimens of this shelf-bathyal (Sen Gupta et al., 2009b) species, frequently assigned to the genus Cassidulinoides, have been collected from the sample STZC 24.

Genus GLOBOCASSIDULINA Voloshinova, 1960

Globocassidulina subglobosa (Brady, 1881) Figure 9.12

1881 Cassidulina subglobosa Brady: p. 60.

1988 Globocassidulina subglobosa (Brady); Amore, Barra, Ciampo, Ruggiero Taddei, Russo and Sgarrella, p. 975.

1990 Globocassidulina subglobosa (Brady); Amore, Barra, Ciampo, Ruggiero Taddei, Russo and Sgarrella, pp. 481-482. 2009a Globocassidulina subglobosa (Brady); Sen Gupta, Lobegeier and Smith, pp. 74-75, pl. 68 , figs. $1-4$.

Distribution and remarks. An eurybathic species, mostly circalittoral and bathyal, living in organic rich sediments, capable of tolerating dysoxic waters (Jorissen et al., 2007; Sen Gupta et al., 2009a). Uncommon at La Starza, it is present in the Section $C$ showing RA range from $0.27 \%$ to $1.43 \%$.

Family STAINFORTHIIDAE Reiss, 1963

Genus STAINFORTHIA Hofker, 1956

Stainforthia complanata (Egger, 1893)

Figure 8.19

1893 Virgulina schreibersiana Czjzek var. complanata Egger: pp. 292-293, pl. 8, figs. 91-92.

1988 Stainforthia complanata (Egger); Amore, Barra, Ciampo, Ruggiero Taddei, Russo and Sgarrella, p. 974.

1990 Stainforthia complanata (Egger); Amore, Barra, Ciampo, Ruggiero Taddei, Russo and Sgarrella, pp. 480, 482.

2009a Stainforthia complanata (Egger); Sen Gupta, Lobegeier and Smith, p. 76, pl. 171, figs. 1-5.

Distribution and remarks. An eurybathic species (Sen Gupta et al., 2009b), occurring mostly in lower infralittoral and upper circalittoral zone (Sgarrella and Moncharmont, 1993). In the La Starza outcrops $S$. complanata has been recorded in the majority of the fossiliferous samples, with low abundance values $(R A=0.18 \%-2.29 \%)$.

Family SIPHOGENERINOIDIDAE Saidova, 1981

Subfamily TUBULOGENERININAE Saidova, 1981

Genus RECTUVIGERINA Mathews, 1945

Rectuvigerina phlegeri Le Calvez, 1959

Figure 9.15

1959 Rectuvigerina phlegeri Le Calvez in Berthois and Le Calvez: p. 363, pl. 1, fig. 11.

1988 Rectuvigerina phlegeri Le Calvez; Amore, Barra, Ciampo, Ruggiero Taddei, Russo and Sgarrella, p. 974.

1990 Rectuvigerina phlegeri Le Calvez; Amore, Barra, Ciampo, Ruggiero Taddei, Russo and Sgarrella, pp. 480, 482, pl. 2, fig. 2.

2012 Rectuvigerina phlegeri Le Calvez; Milker and Schmiedl, p. 86, fig. 20.18.

Distribution and remarks. Rectuvigerina phlegeri is a stress tolerant, opportunistic shelf species, common in eutrophic, hypoxic environments (Diz and Francés, 2008; Goineau et al., 2011; Barras et al., 2014). Not rare in the Section C, with RA ranging from $0.19 \%$ to $7.87 \%$. 
FAMILY BULIMINIDAE Jones, 1875 Genus BULIMINA d'Orbigny, 1826 Bulimina aculeata d'Orbigny, 1826

Figure 9.16

1826 Bulimina aculeata d'Orbigny: p. 269, no. 7.

1988 Bulimina aculeata d'Orbigny; Amore, Barra, Ciampo, Ruggiero Taddei, Russo and Sgarrella, p. 974.

1990 Bulimina aculeata d'Orbigny; Amore, Barra, Ciampo, Ruggiero Taddei, Russo and Sgarrella, pp. 480, 482.

2012 Bulimina aculeata d'Orbigny; Milker and Schmiedl, p. 87, fig. 20.19.

Distribution and remarks. Bulimina aculeata is an opportunistic species that tolerates low-oxygen environment, with degraded organic matter (Schmiedl et al., 2000, and references therein). It occurs from the infralittoral to the bathyal zone, showing its optimum within the circalittoral zone (40-130 m; Jorissen, 1988; v. Avnaim-Katav et al., 2013 for extensive references). Relatively common in the La Starza sediments (RA range: $0.51 \%$ $5.10 \%)$.

Bulimina elongata d'Orbigny, 1846

Figure 9.17

1846 Bulimina elongata d'Orbigny: p. 187, pl. 11, figs. 19-20.

1988 Bulimina elongata d'Orbigny; Amore, Barra, Ciampo, Ruggiero Taddei, Russo and Sgarrella, p. 974.

1990 Bulimina elongata d'Orbigny; Amore, Barra, Ciampo, Ruggiero Taddei, Russo and Sgarrella, pp. 480, 482, pl. 2, figs. 3-4.

2012 Bulimina elongata d'Orbigny; Milker and Schmiedl, p. 88, fig. 20.21.

Distribution and remarks. The species occurs in shelf Mediterranean areas, on fine grained sediment bottom. Mainly recorded within the infralittoral zone, it prefers low energy-low oxygen waters, with high organic matter waters (Jorissen, 1988; Eichler et al., 2003). Bulimina elongata is one of the characteristic species of the La Starza assemblages (RA range: $1.02 \%-10.34 \%$ ).

Bulimina marginata d'Orbigny, 1826

Figure 9.18

1826 Bulimina marginata d'Orbigny: p. 269, pl. 12, figs. 10-12.

1988 Bulimina marginata d'Orbigny; Amore, Barra, Ciampo, Ruggiero Taddei, Russo and Sgarrella, p. 974.

1990 Bulimina marginata d'Orbigny; Amore, Barra, Ciampo, Ruggiero Taddei, Russo and Sgarrella, pp. 480, 482.
2012 Bulimina marginata d'Orbigny; Milker and Schmiedl, p. 88, fig. 20.23 .

Distribution and remarks. Bulimina marginata is recorded from the infralittoral to the bathyal zone, and shows preference for circalittoral organic rich muds. It is tolerant to low oxygen bottom waters (Sen Gupta et al., 2009b; Davidsson, 2014). This accessory species occurs in five samples of the section $C$, with RA ranging from $0.21 \%$ to $3.39 \%$.

FAMILY UVIGERINIDAE Haeckel, 1894

Subfamily ANGULOGERININAE Galloway, 1933

Genus TRIFARINA Cushman, 1923

Trifarina angulosa (Williamson, 1858)

Figure 9.19

1858 Uvigerina angulosa Williamson: p. 67, pl. 5, fig. 140.

1988 Trifarina angulosa (Williamson); Amore, Barra, Ciampo, Ruggiero Taddei, Russo and Sgarrella, p. 974.

1990 Trifarina angulosa (Williamson); Amore, Barra, Ciampo, Ruggiero Taddei, Russo and Sgarrella, pp. 480, 482.

2010 Trifarina angulosa (Williamson); Hayward, Grenfell, Sabaa, Neil and Buzas, p. 204, pl. 21, figs. 12-15.

Distribution and remarks. Trifarina angulosa is typical of lower circalittoral-bathyal environment, preferring well oxygenated, high energy bottoms, with sustained food input (Hayward et al., 2002). This accessory species is present in 11 samples of Section C and in the sample STZB 5.

Family REUSSELLIDAE Cushman, 1933 Genus REUSSELLA Galloway, 1933 Reussella spinulosa (Reuss, 1850)

Figure 9.14

1850a Verneuilina spinulosa Reuss: p. 374, pl. 47, fig. 12.

1964 Reussella spinulosa (Reuss); Rodriquez, p. 115 , pl. 6, fig. II.7.

1988 Reussella spinulosa (Reuss); Amore, Barra, Ciampo, Ruggiero Taddei, Russo and Sgarrella, p. 974

1990 Reussella spinulosa (Reuss); Amore, Barra, Ciampo, Ruggiero Taddei, Russo and Sgarrella, pp. 480, 482.

1998 Reussella spinulosa (Reuss); Cicha, Rögl, Rupp and Ctyroka, p. 124, pl. 54, figs. 16-17.

2012 Reussella spinulosa (Reuss); Milker and Schmiedl, p. 92, figs. 21.6-7.

Distribution and remarks. A phytophilous shelf species (Szarek, 2001) common on sandy bottoms in the upper circalittoral zone of the Mediterranean (Jorissen, 1987; Barmawidjaja et al., 1995; 
Avnaim-Katav et al., 2015). Present in the majority of the fossiliferous samples at La Starza, with RA ranging from $0.46 \%$ to $11.94 \%$.
Family FURSENKOINIDAE Loeblich and Tappan, 1961
Fursenkoina subacuta (d'Orbigny, 1852)
Figure 10.1

1846 Polymorphina acuta d'Orbigny: p. 234, pl. 13, figs. 4-5; pl. 14, figs. 5-7 (non Polymorphina acuta Roemer, 1838).

1852 Polymorphina subacuta d'Orbigny: p. 159 (new name).

2012 Fursenkoina acuta (d'Orbigny); Milker and Schmiedl, pp. 92-93, figs. 21.10-11.

2017 Fursenkoina subacuta (d'Orbigny); Harzhauser, Theobalt, Strauss, Mandic, Carnevale and Piller, pl. 1, fig. 26.

Distribution and remarks. This accessory infracircalittoral, stress tolerant species, (Sgarrella and Moncharmont-Zei, 1993; Bergin et al., 2006; Avnaim-Katav et al., 2013; as F. acuta) is present at La Starza in 16 samples, with low percent values $(R A=0.18 \%-0.66 \%)$.

Fursenkoina tenuis (Seguenza, 1862)

Figure 10.2

1862 Virgulina tenuis Seguenza: p. 112, pl. 2, fig. 2.

1988 Fursenkoina tenuis (Seguenza); Amore, Barra, Ciampo, Ruggiero Taddei, Russo and Sgarrella, p. 975.

1990 Fursenkoina tenuis (Seguenza); Amore, Barra, Ciampo, Ruggiero Taddei, Russo and Sgarrella, p. 481.

1993 Fursenkoina tenuis (Seguenza); Sgarrella and Moncharmont-Zei, p. 236, pl. 23, fig. 12.

Distribution and remarks. A circalittoral, mainly bathyal species, rare in lower infralittoral zone (Sgarrella and Moncharmont-Zei, 1993), present with few specimens in three samples of Section C.

Family BAGGINIDAE Cushman, 1927

Subfamily BAGGININAE Cushman, 1927

Genus CANCRIS de Montfort, 1808

Cancris auricula (Fichtel and Moll, 1798)

$1798 \quad$ Nautilus auricula Fichtel and Moll: p. 108, pl. 20, figs. a-f.

2003 Cancris auricula (Fichtel and Moll); Murray, p. 19, figs. 6.6-6.7.

Distribution and remarks. Few specimens of this shelf-bathyal species, linked to high organic matter (Altenbach et al., 2003), are present in the sample STZB 5. It tolerates suboxic bottom waters (Jorissen et al., 2007).
Genus VALVULINERIA Cushman, 1926

Valvulineria complanata (d'Orbigny, 1846)

Figure 10.3

1846 Rosalina complanata d'Orbigny: p. 175, pl. 10, figs. 13-15.

1988 Valvulineria bradyana (Fornasini); Amore, Barra, Ciampo, Ruggiero Taddei, Russo and Sgarrella, p. 974.

1990 Valvulineria bradyana (Fornasini); Amore, Barra, Ciampo, Ruggiero Taddei, Russo and Sgarrella, pp. 481-482.

2012 Valvulineria complanata (d'Orbigny); Milker and Schmiedl, pp. 93-94, figs. 10.13-15.

Distribution and remarks. This species has been frequently cited as Valvulineria bradyana (Fornasini, 1900) that is a younger synonym of $V$. complanata (Milker and Schmiedl, 2012). It is an opportunistic form, common in high organic matter, low oxygen environment (Goineau et al., 2011). Valvulineria complanata is recorded in the shelf upper bathyal zone, occurring mainly in the upper circalittoral zone (Frezza and Carboni, 2009; Sen Gupta et al., 2009b; Avnaim-Katav et al., 2015). The species occurs, rare, in the upper part of Section $\mathrm{C}$.

Family DISCORBIDAE Ehrenberg, 1838

Genus ROTORBIS Sellier de Civrieux, 1977 Rotorbis auberii (d'Orbigny, 1839)

Figure 10.6

1839a Rosalina auberii d'Orbigny: p. 94, pl. 4, figs. 5-8.

1988 Discorbis mira Cushman; Amore, Barra, Ciampo, Ruggiero Taddei, Russo and Sgarrella, p. 974.

1990 Discorbis mira Cushman; Amore, Barra, Ciampo, Ruggiero Taddei, Russo and Sgarrella, p. 482.

1992 Rotorbis auberii (d'Orbigny); Hansen and Revets, p. 175, pl. 1, figs. 1-3, 7.

Distribution and remarks. Rotorbis auberii is an infralittoral-circalittoral species frequently cited as Discorbis mira Cushman, 1922 (Sgarrella and Moncharmont Zei, 1993). At La Starza is present with few individuals in the samples STZC 15 and STZC 29.

Family ROSALINIDAE Reiss, 1963

Genus GAVELINOPSIS Hofker, 1951

Gavelinopsis praegeri (Heron-Allen and Earland, 1913)

Figure 10.4-5

1913 Discorbina praegeri Heron-Allen and Earland: p. 122 , pl. 10 , figs. 8-10. 


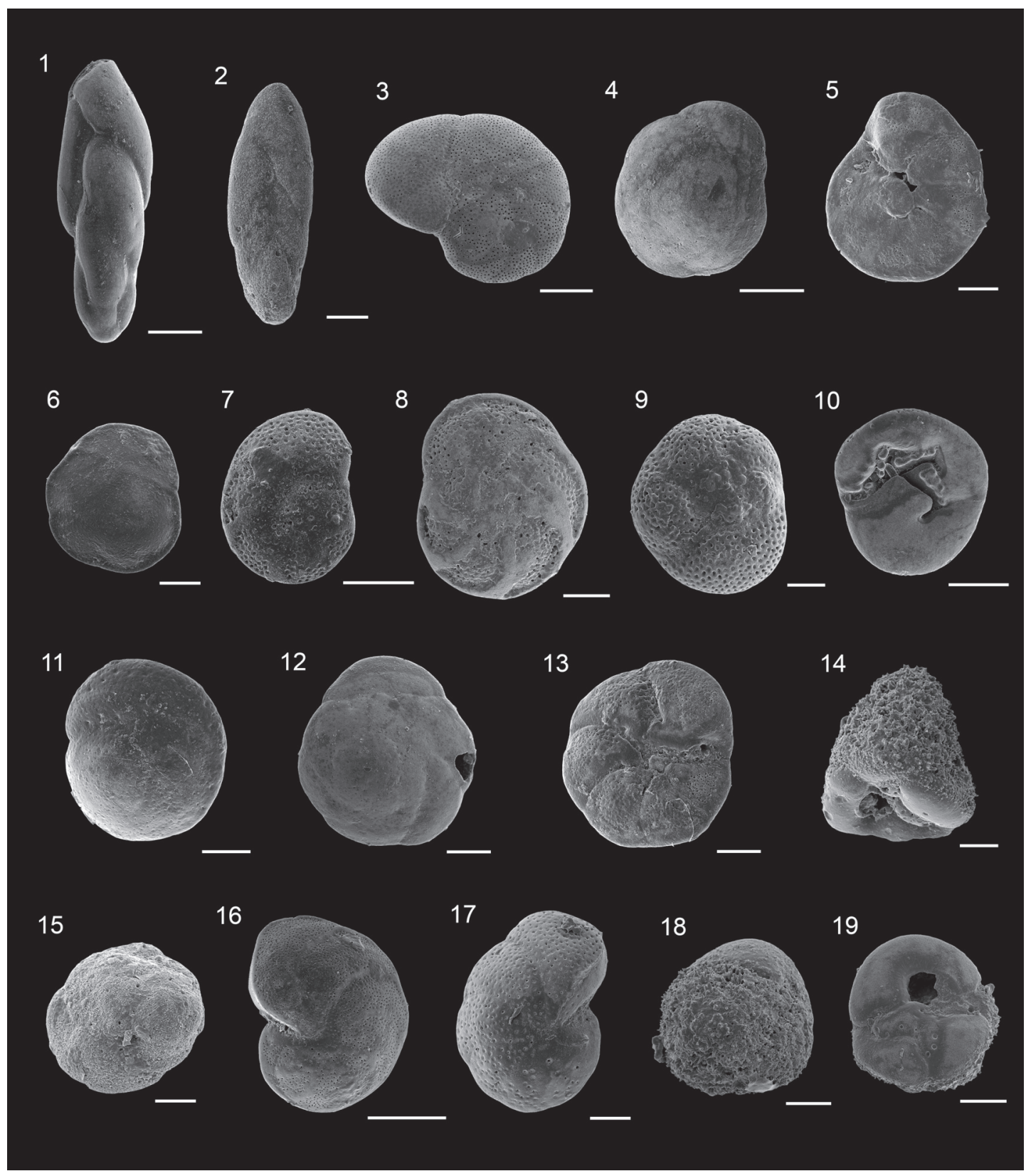

FIGURE 10. 1 Fursenkoina subacuta (d'Orbigny, 1852), lateral view, sample STZB 6, ABMC 2016/025; 2 Fursenkoina tenuis (Seguenza, 1862), lateral view, sample STZC 22, ABMC 2016/057; 3 Valvulineria complanata (d'Orbigny, 1846), spiral side, sample STZC 33, ABMC 2016/009; 4 Gavelinopsis praegeri (Heron-Allen and Earland, 1913), spiral side, sample STZC 19, ABMC 2016/082; 5 Gavelinopsis praegeri (Heron-Allen and Earland, 1913), umbilical side, sample STZC 19, ABMC 2016/083; 6 Rotorbis auberii (d'Orbigny, 1839), spiral side, sample STZC 29, ABMC 2016/069; 7 Rosalina floridana (Cushman, 1922), spiral side, sample STZC 31, ABMC 2016/029; 8 Rosalina macropora (Hofker, 1951), spiral side, sample STZC 26, ABMC 2016/030; 9 Rosalina obtusa d'Orbigny, 1846, spiral side, sample STZC 33, ABMC 2016/090; 10 Rosalina obtusa d'Orbigny, 1846, umbilical side, sample STZC 33, ABMC 2016/089; 11 Tretomphalus concinnus (Brady, 1884), spiral side, sample STZC 31, ABMC 2016/065; 12 Epistominella vitrea Parker, 1953, spiral side, sample STZC 30, ABMC 2016/078; 13 Epistominella vitrea Parker, 1953, umbilical side, sample STZC 19, ABMC 2016/070; 14 Glabratella erecta (Sidebottom, 1908), side view, sample STZC 28, ABMC 2016/071; 15 Glabratella hexacamerata Seiglie and Bermudez, 1965, spiral side, sample STZC 15, ABMC 2016/066; 16 Discorbinella bertheloti (d'Orbigny, 1839), spiral side, sample STZC 33, ABCM 2017/031; 17 Cibicides lobatulus (Walker and Jacob, 1798), spiral side, sample STZC 19, ABMC 2016/001; 18 Asterigerinata adriatica Haake, 1977, spiral side, sample STZC 31, ABMC 2016/011; 19 Asterigerinata adriatica Haake, 1977, umbilical side, sample STZC 31, ABMC 2016/012. Scale bar 2, 5, 6, 9-15, 18, 19 - $50 \mu \mathrm{m} ; 1,3,4,7,8,16,17-100 \mu \mathrm{m}$. 
1988 Gavelinopsis praegeri (Heron-Allen and Earland); Amore, Barra, Ciampo, Ruggiero Taddei, Russo and Sgarrella, p. 974.

1990 Gavelinopsis praegeri (Heron-Allen and Earland); Amore, Barra, Ciampo, Ruggiero Taddei, Russo and Sgarrella, pp. 480, 482.

2010 Gavelinopsis praegeri (Heron-Allen and Earland); Hayward, Grenfell, Sabaa, Neil and Buzas, p. 230, pl. 31, figs. 14-21.

2012 Gavelinopsis praegeri (Heron-Allen and Earland); Milker and Schmiedl, p. 97, figs. 22.3-4.

Distribution and remarks. An eurybathic species (Hayward et al., 2010), recorded in shelf and bathyal environment, very rare in the upper infralittoral zone (Aiello, Barra and Parisi, pers. obs.), epifaunal on hard substrates (Murray, 2006). Not rare in the La Starza assemblages, with RA ranging from $0.32 \%$ to $6.94 \%$.

Genus ROSALINA d'Orbigny, 1826

Rosalina floridana (Cushman, 1922) Figure 10.7

1922 Discorbis floridana Cushman: p. 39, pl. 5, figs. 11-12.

1979 Rosalina floridana (Cushman); Angell, pl. 1, figs. 1-2.

2012 Rosalina floridana (Cushman); Debenay, pp. 211, 310.

Distribution and remarks. An eurybathic (Sen Gupta et al., 2009b) species, mainly recorded in the infralittoral and upper circalittoral zone (Javaux and Scott, 2003; Murray, 2014). It occurs in Section C, mainly in the upper part, with low RA values.

Rosalina macropora (Hofker, 1951)

Figure 10.8

1951 Discopulvinulina macropora Hofker: p. 460, figs. 312-313.

1988 Rosalina bradyi (Cushman); Amore, Barra, Ciampo, Ruggiero Taddei, Russo and Sgarrella, p. 974.

1990 Rosalina bradyi (Cushman); Amore, Barra, Ciampo, Ruggiero Taddei, Russo and Sgarrella, pp. 481-482.

2012 Rosalina macropora (Hofker); Milker and Schmiedl, p. 99, figs. 22.17-18.

Distribution and remarks. A phytal species recorded in the infralittoral and, subordinately, in the circalittoral zone (Sgarrella and MoncharmontZei, 1993, as R. bradyi; Milker and Schmiedl, 2012). Rosalina macropora is present mainly in the upper part of Section $C$, always rare.

Rosalina obtusa d'Orbigny, 1846

Figure 10.9-10
1846 Rosalina obtusa d'Orbigny: p. 179, tab.11, figs. 4-6.

1988 Rosalina obtusa d'Orbigny; Amore, Barra, Ciampo, Ruggiero Taddei, Russo and Sgarrella, p. 974.

1990 Rosalina obtusa d'Orbigny; Amore, Barra, Ciampo, Ruggiero Taddei, Russo and Sgarrella, pp. 481-482.

1993 Rosalina obtusa d'Orbigny; Sgarrella and Moncharmont Zei, p. 219, pl. 17, figs. 9-10.

1998 Rosalina obtusa d'Orbigny; Cicha, Rögl, Rupp and Ctyroka, p. 124, pl. 60, figs. 1-3.

Distribution and remarks. Rosalina obtusa is a phytophilous species mainly present in infralittoral and upper circalittoral zone (Sgarrella and Moncharmont Zei, 1993). It occurs mainly in the upper part of the Section C (RA from $0.25 \%$ to $5.11 \%$ ).

Genus TRETOMPHALUS Möbius, 1880

Tretomphalus concinnus (Brady, 1884)

Figure 10.11

1884 Discorbina concinna Brady: p. 646, pl. 90, fig. 7.

2012 Tretomphalus concinnus (Brady); Milker and Schmiedl, p. 99, figs. 22.24-25.

Distribution and remarks. A shelf species (Szarek, 2001; Sen Gupta et al., 2009b) more common in the lower infralittoral and upper circalittoral zone (Sgarrella and Moncharmont Zei, 1993). Present in three samples of the Section $C$, with low RA values.

Family PSEUDOPARRELLIDAE Voloshinova, 1952

Genus EPISTOMINELLA Husezima and Maruhasi, 1944

Epistominella vitrea Parker, 1953

Figure 10.12-13

1953 Epistominella vitrea Parker (in Parker, Phleger and Peirson): p. 9, pl. 4, figs. 34-36, 40, 41.

1988 Epistominella vitrea Parker; Amore, Barra, Ciampo, Ruggiero Taddei, Russo and Sgarrella, p. 974.

1990 Epistominella vitrea Parker; Amore, Barra, Ciampo, Ruggiero Taddei, Russo and Sgarrella, p. 482.

2009a Epistominella vitrea Parker; Sen Gupta, Lobegeier and Smith, p. 91, pl. 60, figs. 1a-c.

Distribution and remarks. An infaunal, opportunistic, eurybathic species common in bathyal environment, tolerating low oxic bottom waters (Jorissen et al., 2007; Margreth et al., 2009; Sen Gupta et al., 2009b). Rare at La Starza, with a RA range of $0.59 \%-1.74 \%$. 
Family GLABRATELLIDAE Loeblich and Tappan, 1964

Genus GLABRATELLA Dorreen, 1948

Glabratella erecta (Sidebottom, 1908)

Figure 10.14

1908 Discorbina erecta Sidebottom: p. 16, pl. 5, figs. 6-7.

2012 Glabratella erecta (Sidebottom, 1908); Milker and Schmiedl, p. 102, figs. 23.12-13.

Distribution and remarks. Glabratella erecta is an infralittoral and upper circalittoral species (Sgarrella and Moncharmont Zei, 1993; Milker and Schmiedl, 2012) very rare at La Starza. Few tests have been found in the sample STZC 28.

Glabratella hexacamerata Seiglie and Bermudez, 1965

Figure 10.15

1965 Glabratella hexacamerata Seiglie and Bermudez: p. 31, pl. 1, figs. 6-7.

2012 Glabratella hexacamerata Seiglie and Bermudez; Milker and Schmiedl, p. 102, figs. 23.14-15.

Distribution and remarks. Few specimens of this infralittoral and upper circalittoral species (Sen Gupta et al., 2009b; Milker and Schmiedl, 2012) have been recorded in the sample STZC 15.

Family DISCORBINELLIDAE Sigal, 1952

Subfamily DISCORBINELLINAE Sigal, 1952

Genus DISCORBINELLA Cushman and Martin, 1935

Discorbinella bertheloti (d'Orbigny, 1839)

Figure 10.16

1839b Rosalina bertheloti d'Orbigny: p. 135, pl. 1, figs. 28-30.

2012 Discorbinella bertheloti (d'Orbigny); Milker and Schmiedl, p. 104, figs. 23.29-30.

Distribution and remarks. The species is recorded from infralittoral to middle bathyal waters, on fine grained sediments (Milker et al., 2009; Sen Gupta et al., 2009b). Discorbinella bertheloti is present, rare, in the uppermost part of Section C.

Family CIBICIDIDAE Cushman, 1927

Subfamily CIBICIDINAE Cushman, 1927

Genus CIBICIDES de Montfort, 1808

Cibicides lobatulus (Walker and Jacob, 1798)

Figure 10.17

1798 Nautilus lobatulus Walker and Jacob: p. 642, pl. 14 , fig. 36 .

1964 Cibicides lobatulus (Walker and Jacob); Rodriquez, p. 116, pl. 6, fig. II.4.
1988 Cibicides lobatulus (Walker and Jacob); Amore, Barra, Ciampo, Ruggiero Taddei, Russo and Sgarrella, p. 975.

1990 Cibicides lobatulus (Walker and Jacob); Amore, Barra, Ciampo, Ruggiero Taddei, Russo and Sgarrella, pp. 481-482.

2009 Cibicides lobatulus (Walker and Jacob); Schweizer, Pawlowski, Kouwenhoven and van der Zwaan, pp. 124-125, figs. 3.2.d-i; figs. 5aI.

Distribution and remarks. The species, frequently reported as Lobatula Iobatula, lives attached on algae or hard substrates in well oxygenated waters (Jorissen et al., 2007). Mainly occurring in infralittoral - upper circalittoral environment (Sgarrella and Moncharmont Zei, 1993), C. lobatulus can be considered an eurybathic species (Szarek, 2001; Sen Gupta et al., 2009b). At La Starza section it is present in the main part of the fossiliferous samples, generally with low RA values, ranging from $0.19 \%$ to $7.32 \%$.

Family ASTERIGERINATIDAE Reiss, 1963

Genus ASTERIGERINATA Bermudez, 1949

Asterigerinata adriatica Haake, 1977

Figure 10.18-19

1977 Asterigerinata adriatica Haake: p. 69, pl. 3, figs. 1-5.

1988 Asterigerinata adriatica Haake; Amore, Barra, Ciampo, Ruggiero Taddei, Russo and Sgarrella, p. 974.

1990 Asterigerinata adriatica Haake; Amore, Barra, Ciampo, Ruggiero Taddei, Russo and Sgarrella, pp. 481-482, pl. 2, figs. 7-8.

2012 Asterigerinata adriatica Haake; Milker and Schmiedl, p. 111, figs. 25.7-9.

Distribution and remarks. Asterigerinata adriatica is a lower infralittoral - upper bathyal species, not recorded above 24 mbsl (optimum: $50-130 \mathrm{~m}$ bsl; Sgarrella and Moncharmont, 1993), showing preference for muddy bottoms (Haake, 1977). It occurs in the majority of the fossiliferous samples of La Starza with RA ranging from $0.51 \%$ to $15.14 \%$.

Asterigerinata mamilla (Williamson, 1858)

Figure 11.1-2

1858 Rotalina mamilla Williamson: p. 54, pl. 4, figs. 109-111.

1988 Asterigerinata mamilla (Williamson); Amore, Barra, Ciampo, Ruggiero Taddei, Russo and Sgarrella, p. 974.

1990 Asterigerinata mamilla (Williamson); Amore, Barra, Ciampo, Ruggiero Taddei, Russo and Sgarrella, pp. 481-482, pl. 2, figs. 7-8.

2012 Asterigerinata mamilla (Williamson); Milker and Schmiedl, p. 111, figs. 25.10-13. 


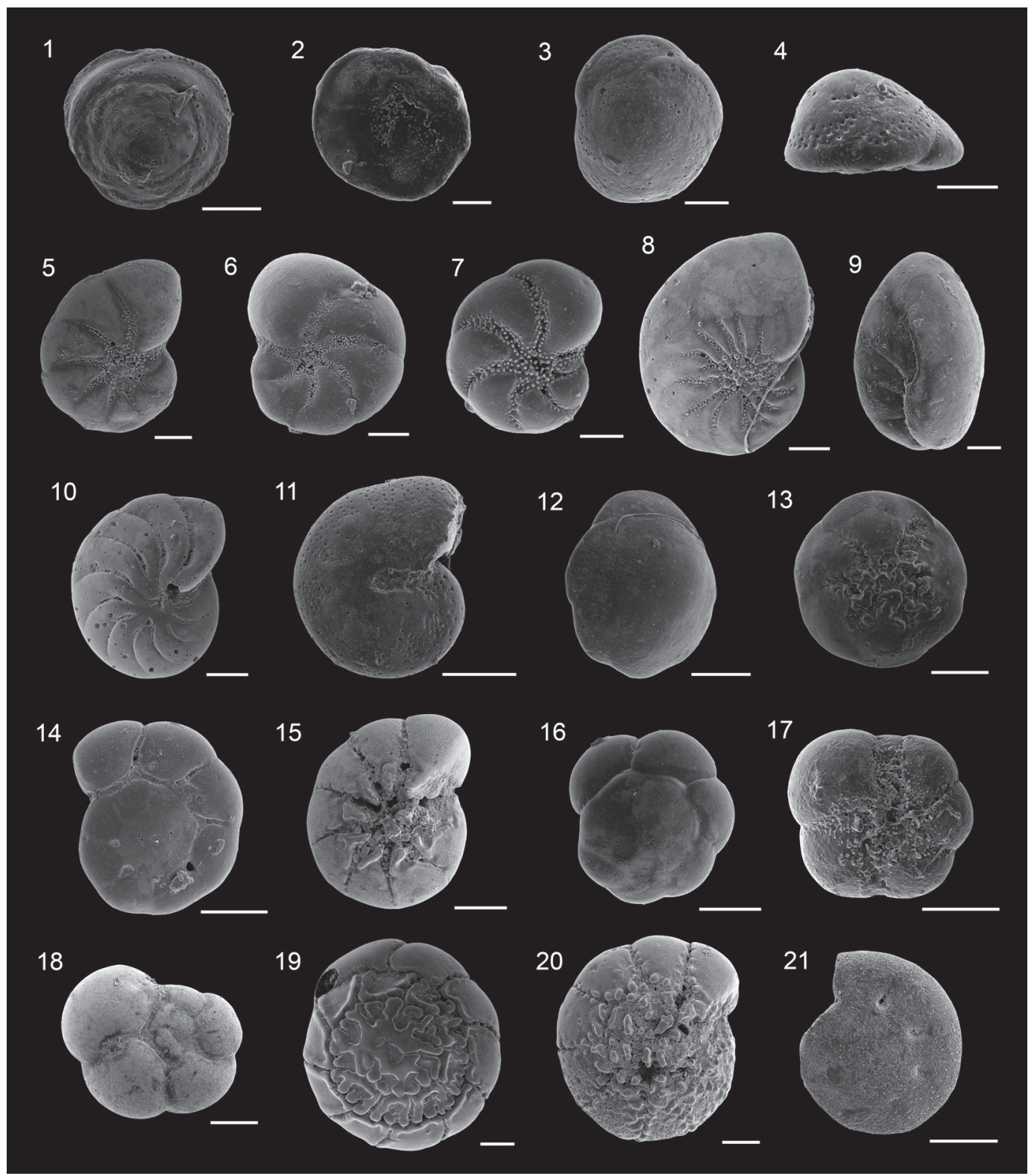

FIGURE 11. 1 Asterigerinata mamilla (Williamson, 1858), spiral side, sample STZC 31, ABMC 2016/013; 2 Asterigerinata mamilla (Williamson, 1858), umbilical side, sample STZC 31, ABMC 2017/001; 3 Asterigerinata mariae Sgarrella, 1990, spiral side, sample STZC 29, ABMC 2016/091; 4 Asterigerinata mariae Sgarrella, 1990, oblique peripheral view, sample STZC 18, ABMC 2017/013; 5 Haynesina depressula (Walker and Jacob, 1798), side view, sample STZC 18, ABMC 2016/036; 6 Haynesina germanica (Ehrenberg, 1840), side view, sample STZC 28, ABMC 2016/064; 7 Haynesina germanica (Ehrenberg, 1840), spiral side, sample STZC 29, ABMC 2016/055; 8 Nonion fabum (Fichtel and Moll, 1798), side view, sample STZC 32, ABMC 2016/054; 9 Nonionella turgida (Williamson, 1858), side view, sample STZC 18, ABMC 2016/024; 10 Astrononion stelligerum (d'Orbigny, 1839), umbilical side, sample STZC 32, ABMC 2016/043; 11 Melonis affinis (Reuss, 1851), side view, sample STZC15, ABMC 2016/018; 12 Buccella granulata (Di Napoli Alliata, 1952), spiral side, sample STZC 29, ABMC 2016/014; 13 Buccella granulata (Di Napoli Alliata, 1952), umbilical side, sample STZC 29, ABMC 2016/015; 14 Ammonia aberdoveyensis Haynes, 1973 rounded form, spiral side, sample STZC 29, ABMC 2016/002; 15 Ammonia aberdoveyensis Haynes, 1973 rounded form, umbilical side, sample STZC 23, ABMC 2016/068; 16 Ammonia aberdoveyensis Haynes, 1973 lobate form, spiral side, sample STZC 27, ABMC 2016/021; 17 Ammonia aberdoveyensis Haynes, 1973 lobate form, umbilical side, sample STZC 19, ABMC 2016/077; 18 Aubignyna perlucida (Heron-Allen and Earland, 1913), spiral side, sample STZC 23, ABMC 2016/027; 19 Ammonia beccarii (Linnaeus, 1758), spiral side, sample STZC 29, ABMC 2016/045; 20 Ammonia beccarii (Linnaeus, 1758), umbilical side, sample STZC 29, ABMC 2016/062; 21 Ammonia falsobeccarii (Rouvillois, 1974), spiral side, sample STZC 13, ABMC 2016/051; Scale bar 2-7, 9 - 50 m; 1, 8, 10-21 
Distribution and remarks. Asterigerinata mamilla occurs in infralittoral (optimum; Phipps et al., 2010), circalittoral and subordinately upper bathyal well oxygenated waters, mainly on sandy-vegetated bottoms (Sgarrella and Moncharmont Zei, 1993). An accessory species, present in ten samples of the Section $C(R A=0.19 \%-1.02 \%)$ and two of the Section $B(R A=0.16 \%-1.91 \%)$.

Asterigerinata mariae Sgarrella, 1990

Figure 11.3-4

1988 Asterigerinata sp. Amore, Barra, Ciampo, Ruggiero Taddei, Russo and Sgarrella: $p$. 975.

1990 Asterigerinata mariae Sgarrella (in Amore, Barra, Ciampo, Ruggiero Taddei, Russo and Sgarrella): pp. 477-478, pl. 3, figs. 1-8.

2012 Asterigerinata mariae Sgarrella; Milker and Schmiedl, p. 111, figs. 25.14-16.

Distribution and remarks. Asterigerinata mariae (epiphytic) is recorded on infralittoral fine sands/ vegetated (optimum) and circalittoral/detritic bottoms (Sgarrella and Moncharmont Zei, 1993). It is present in the majority of the samples of the section C (RA range: $0.25 \%-4.88 \%$ ) and in the sample STZB 5 (1.59\%).

Family NONIONIDAE Schultze, 1854

Subfamily NONIONINAE Schultze, 1854

Genus HAYNESINA Banner and Culver, 1978

Haynesina depressula (Walker and Jacob, 1798) Figure 11.5

1798 Nautilus depressulus Walker and Jacob: p. 641 , pl. 14, fig. 33.

1988 Haynesina depressula (Walker and Jacob); Amore, Barra, Ciampo, Ruggiero Taddei, Russo and Sgarrella, p. 975.

1990 Haynesina depressula (Walker and Jacob); Amore, Barra, Ciampo, Ruggiero Taddei, Russo and Sgarrella, pp. 481-482, pl. 1, figs. 4-5.

2012 Haynesina depressula (Walker and Jacob); Milker and Schmiedl, p. 112, figs. 25.17-18.

Distribution and remarks. A paralic-shallow marine species, mainly infralittoral (Sgarrella and Moncharmont Zei, 1993, as Nonion depressulum) which tolerates polyhaline waters (salinity $>24 \%$; Alve and Murray, 1999) and stressed environment (Bergin et al., 2006); common in the La Starza sediments (RA range: $0.92 \%$ to $12.79 \%$ ).

Haynesina germanica (Ehrenberg, 1840)

Figure 11.6-7

$1840 \quad$ Nonionina germanica Ehrenberg: p. 23.

1978 Haynesina germanica (Ehrenberg); Banner and Culver, pp. 191-200, pl. 4, figs. 1-6; pl. 5, figs. 1-8; pl. 6, figs. 1-7; pl. 7, figs. 1-6; pl. 8, figs. 1-10; pl. 9, figs. 1-11, 15, 17-18.

1988 Nonion pauciloculum (Cushman); Amore, Barra, Ciampo, Ruggiero Taddei, Russo and Sgarrella, p. 975.

1990 Nonion pauciloculum (Cushman); Amore, Barra, Ciampo, Ruggiero Taddei, Russo and Sgarrella, pp. 481-482, pl. 2, fig. 2.

2004 Haynesina germanica (Ehrenberg); Armynot du Châtelet, Debenay and Soulard, pl. 1, figs. 5-6.

2013 Haynesina germanica (Ehrenberg); Pillet, Voltski, Korsun and Pawlowski, pl. 1, figs. c-d.

Distribution and remarks. Haynesina germanica is an euryhaline, eurythermal species, present in marginal, infralittoral and upper circalittoral environment, tolerant to polluted and stressed environments (Banner and Culver, 1978; Armynot du Châtelet et al., 2004; Armynot du Châtelet and Debenay, 2010). The species, frequently recorded (Coccioni et al., 2009) as Nonion pauciloculum, Elphidium pauciloculum and Haynesina paucilocula (Cushman, 1944) is not rare in the La Starza sediments, ranging from $0.41 \%$ to $3.64 \%$.

Genus NONION de Montfort, 1808

Nonion fabum (Fichtel and Moll, 1798)

Figure 11.8

1798 Nautilus faba Fichtel and Moll: p. 103, pl. 19, figs. a-c.

2012 Nonion fabum (Fichtel and Moll); Milker and Schmiedl, p. 73, figs. 18.21.

Distribution and remarks. Nonion fabum is an outer shelf - upper bathyal species (Szarek, 2001), linked to organic matter (Goineau et al., 2011) and tolerant to low oxygen levels (Mojtahid et al., 2010). The species is present at La Starza in eight samples generally with low RA values $(0.19 \%$ $5.13 \%)$.

Genus NONIONELLA Cushman, 1926

Nonionella turgida (Williamson, 1858) Figure 11.9

1858 Rotalina turgida Williamson: p. 50, pl. 4, figs. 95-97.

1988 Nonionella turgida (Williamson); Amore, Barra, Ciampo, Ruggiero Taddei, Russo and Sgarrella, p. 975.

1990 Nonionella turgida (Williamson); Amore, Barra, Ciampo, Ruggiero Taddei, Russo and Sgarrella, pp. 481-482, pl. 2, fig. 6 .

2012 Nonionella turgida (Williamson); Milker and Schmiedl, p. 113, figs. 26.1-6.

Distribution and remarks. A shelf-bathyal species, with optimum in the upper circalittoral zone 
(Jorissen, 1987; Sgarrella and Moncharmont Zei, 1993). N. turgida is considered an opportunistic, stress tolerant species (Bergin et al., 2006; Frontalini and Coccioni, 2011; Barras et al., 2014) able to survive to anoxic conditions (Moodley et al., 1998). Common at La Starza, its RA ranges from $6.90 \%$ to $21.92 \%$.

Subfamily ASTRONONIONINAE Saidova, 1981 Genus ASTRONONION Cushman and Edwards, 1937

Astrononion stelligerum (d'Orbigny, 1839)

Figure 11.10

1839b Nonionina stelligera d'Orbigny: p. 128, pl. 3, figs. 1-2.

2012 Astronion stelligerum (d'Orbigny); Milker and Schmiedl, p. 113, figs. 26.7-8.

Distribution and remarks. A shelf and upper bathyal species (Sen Gupta et al., 2009b; Szarek, $2001)$, showing low RA $(0.18 \%-4.10 \%)$ both in the Section B and C.

Subfamily PULLENIINAE Schwager, 1877

Genus MELONIS de Montfort, 1808 Melonis affinis (Reuss, 1851)

Figure 11.11

$1851 \quad$ Nonionina affinis Reuss: p. 72, pl. 5, fig. 32.

1858 Nonionina barleeana Williamson: p. 32, pl. 3, figs. 68-69.

2009a Melonis affinis (Reuss); Sen Gupta, Lobegeier and Smith, pp. 98-99, pl. 103, figs. 1-2.

Distribution and remarks. We agree with the statement of authors (Van Marle, 1991; Sen Gupta et al., 2009a; Hayward et al., 2010) who consider Nonionina barleeana as a younger synonym of $N$. affinis. It is an eurybathic (Sen Gupta et al., 2009b) species, very rare in the upper infralittoral zone (Sgarrella and Moncharmont-Zei, 1993; Aiello, Barra and Parisi, pers. obs.). Few individuals of $M$. affinis occur at La Starza in the sample STZC 15.

Family TRICHOHYALIDAE Saidova, 1981

Genu AUBIGNYNA Margerel, 1970

Aubignyna perlucida (Heron-Allen and Earland, 1913)

Figure 11.18

1913 Rotalia perlucida Heron-Allen and Earland: $p$. 139, pl. 13, figs. 7-9.

1988 Ammonia perlucida (Heron-Allen and Earland); Amore, Barra, Ciampo, Ruggiero Taddei, Russo and Sgarrella, p. 975.

1990 Ammonia perlucida (Heron-Allen and Earland); Amore, Barra, Ciampo, Ruggiero Taddei, Russo and Sgarrella, pp. 481-482.
2000 Aubignyna perlucida (Heron-Allen and Earland); Murray, Whittaker and Alve, pp. 6164 , pl. 1, figs. 1-14, fig. 1d.

Distribution and remarks. This infaunal, tolerant of stressed environment species (Frontalini and Coccioni, 2008), is present in eight samples of Section C (0.32\%-7.37\%) and two of the Section B (0.62\%-0.64\%).

Genus BUCCELLA Andersen, 1952

Buccella granulata (Di Napoli Alliata, 1952)

Figure 11.12-13

1952 Eponides frigidus (Cushman) var. granulatus Di Napoli Alliata: pp. 103, 107, pl. 5, fig. 3.

1988 Buccella granulata (Di Napoli Alliata); Amore, Barra, Ciampo, Ruggiero Taddei, Russo and Sgarrella, p. 974.

1990 Buccella granulata (Di Napoli Alliata); Amore, Barra, Ciampo, Ruggiero Taddei, Russo and Sgarrella, pp. 480, 482.

2012 Buccella granulata (Di Napoli Alliata); Milker and Schmiedl, p. 117, figs. 26.26-27.

Distribution and remarks. Buccella granulata is common in the infralittoral - upper circalittoral Mediterranean waters, showing preference for vegetated, sandy bottoms (Jorissen, 1987, 1988). The species is recorded at La Starza in the majority of the fossiliferous samples (RA range: $0.25 \%$ to $12.24 \%)$.

Family ROTALIIDAE Ehrenberg, 1839

Subfamily AMMONIINAE Saidova, 1981

Genus AMMONIA Brünnich, 1772

Ammonia aberdoveyensis Haynes, 1973

Figure 11.14-17

1973 Ammonia aberdoveyensis Haynes: pp. 184186, pl. 18, fig. 15; text-figs. 38.1-38.7.

1988 Ammonia parkinsoniana (d'Orbigny); Jorissen, pl. 2, fig. 8; pls. 7-10.

1988 Ammonia tepida (Cushman); Amore, Barra, Ciampo, Ruggiero Taddei, Russo and Sgarrella, p. 975.

1988 Ammonia tepida (Cushman) f. 1; Amore, Barra, Ciampo, Ruggiero Taddei, Russo and Sgarrella, p. 975.

1990 Ammonia tepida (Cushman); Amore, Barra, Ciampo, Ruggiero Taddei, Russo and Sgarrella, pp. 481-482, pl.1, figs. 1-2.

1990 Ammonia tepida (Cushman) f. 1; Amore, Barra, Ciampo, Ruggiero Taddei, Russo and Sgarrella, pp. 481-482.

2004 Molecular type T2 Hayward, Holzmann, Grenfell, Pawlowski and Triggs, pl. 2, T2; pl. 3, T2; pl. 4, T2; tab. 6, T2.

Distribution and remarks. The results of Holzmann and Pawlowski (2000) and Hayward et 
al. (2004), based on rDNA sequences, suggest that the mediterranean form commonly assigned to $A$. parkinsoniana, including $A$. parkinsoniana forma parkinsoniana and $A$. $p$. forma tepida (Cushman, 1926), extensively figured by Jorissen (1988), should be attributed to the Haynes' species. The authors report their Morphotype T2 (=A. aberdoveyensis) from European - North Atlantic microtidal marshes.

Jorissen (1988) recognized the "lobate" form (=A. $p$. forma tepida) as highly tolerant to environmental stress, lowered salinities and low oxygen waters. Bergin et al. (2006), who assigned it to $A$. tepida, have proposed the use of this form as "pollution indicator".

The "rounded" form (=A. $p$. forma parkinsoniana) is considered a morphotype commonly present in low salinity waters and in the depth range 10$20 \mathrm{~m}$. In order to avoid loss of information we have assigned the two morphotypes to $A$. aberdoveyensis "lobate form" and A. aberdoveyensis "rounded form".

A. aberdoveyensis "lobate form" (figs. 11.1617 ) is present in 21 samples of section STZC, with a maximum abundance of $14.83 \%$, and in the two fossiliferous samples of section STZB.

A. aberdoveyensis "rounded form" (figs. 11.14-15) occurs in 17 samples of section STZC, with a maximum RA of $21.19 \%$.

Ammonia beccarii (Linnaeus, 1758)

Figure 11.19-20

1758 Nautilus beccarii Linnaeus: p. 710 [figured by Plancus (1739) as Cornu Hammonis, pl. 1, fig. 1].

1988 Ammonia beccarii (Linnaeus); Jorissen, pp. $52-54$, pl. 2 , fig. 5 , pl. 5 , figs. $1-4$, pl. 6 , figs. $1-$ 4.

1988 Ammonia beccarii (Linnaeus); Amore, Barra, Ciampo, Ruggiero Taddei, Russo and Sgarrella, p. 975

1990 Ammonia beccarii (Linnaeus); Amore, Barra, Ciampo, Ruggiero Taddei, Russo and Sgarrella, pp. 481-482, pl. 1 fig. 3.

1998 Ammonia beccarii (Linnaeus) s.s.; Debenay, Bénéteau, Zhang, Stouff, Geslin, Redois and Fernandez-Gonzalez, pl. 1, figs. 1-5, 8-9.

2004 Ammonia beccarii (Linnaeus); Hayward, Holzmann, Grenfell, Pawlowski and Triggs, pl. 2, fig. b, pl. 3 , fig. b, pl. 4 , fig. b.

Distribution and remarks. Ammonia beccarii is a mostly marine infralittoral species, which shows a preference for sandy and vegetated bottoms (Debenay et al., 1998). Due to the complex taxon- omy of this species (Hayward et al., 2004), its capacity to tolerate low oxic bottom waters (Karlsen et al., 2000; Moodley and Hess, 1992), environmental stress (Yanko et al., 1999; Tsujimoto et al., 2006) as well as its dominance in paralic brackish environments (Murray, 2014) has to be referred to $A$. beccarii sensu lato. At La Starza the species has been recorded in Section $C$, ranging from $0.29 \%$ to $16.13 \%$; its RA is high in low-diversity samples (STZC 16 and STZC 17). It lacks in the samples of the subcluster B2.

\section{Ammonia falsobeccarii (Rouvillois, 1974)}

Figure 11.21

1974 Pseudoeponides falsobeccarii Rouvillois: p. 3, pl. 1, figs. 1-12.

1988 "Pseudoeponides" falsobeccarii Rouvillois; Amore, Barra, Ciampo, Ruggiero Taddei, Russo and Sgarrella, p. 975.

1990 "Pseudoeponides" falsobeccarii Rouvillois; Amore, Barra, Ciampo, Ruggiero Taddei, Russo and Sgarrella, p. 482.

2011 Ammonia falsobeccarii (Rouvillois); Schweizer, Jorissen and Geslin, pp. 95-103.

Distribution and remarks. An infralittoral - upper circalittoral species typical of low-oxic, stressed environments (Schweizer et al., 2011). It is present in two samples of the Section C: STZC 13 $(R A=14.83 \%)$ and STZC $18(R A=0.42 \%)$.

Family ELPHIDIIDAE Galloway, 1933

Subfamily ELPHIDIINAE Galloway, 1933

Genus ELPHIDIUM de Montfort, 1808

Elphidium advenum (Cushman, 1922)

Figure 12.15

1922 Polystomella advena Cushman: p. 56, pl. 9, figs. 11-12.

1988 Elphidium advenum (Cushman); Jorissen, p. 102, pl. 2, figs. 9-10; pl. 24, figs. 3a-b; pl. 25, figs. 4, 6a-b.

Distribution and remarks. Our specimens fit very well with the form figured by Boltovskoy et al. (1980) as E. advenum depressulum Cushman, 1933. In our opinion, the wide morphological variability of the species does not allow the discrimination of $E$. advenum and $E$. a. depressulum not even at subspecific level. It is an infralittoral and upper circalittoral species (Jorissen, 1988; Sen Gupta et al., 2009b) present in six samples of the Section C, uncommon.

Elphidium articulatum (d'Orbigny, 1839)

Figure 12.1-2

1839c Polystomella articulata d'Orbigny: p. 30, pl. 3, figs. 9-10. 


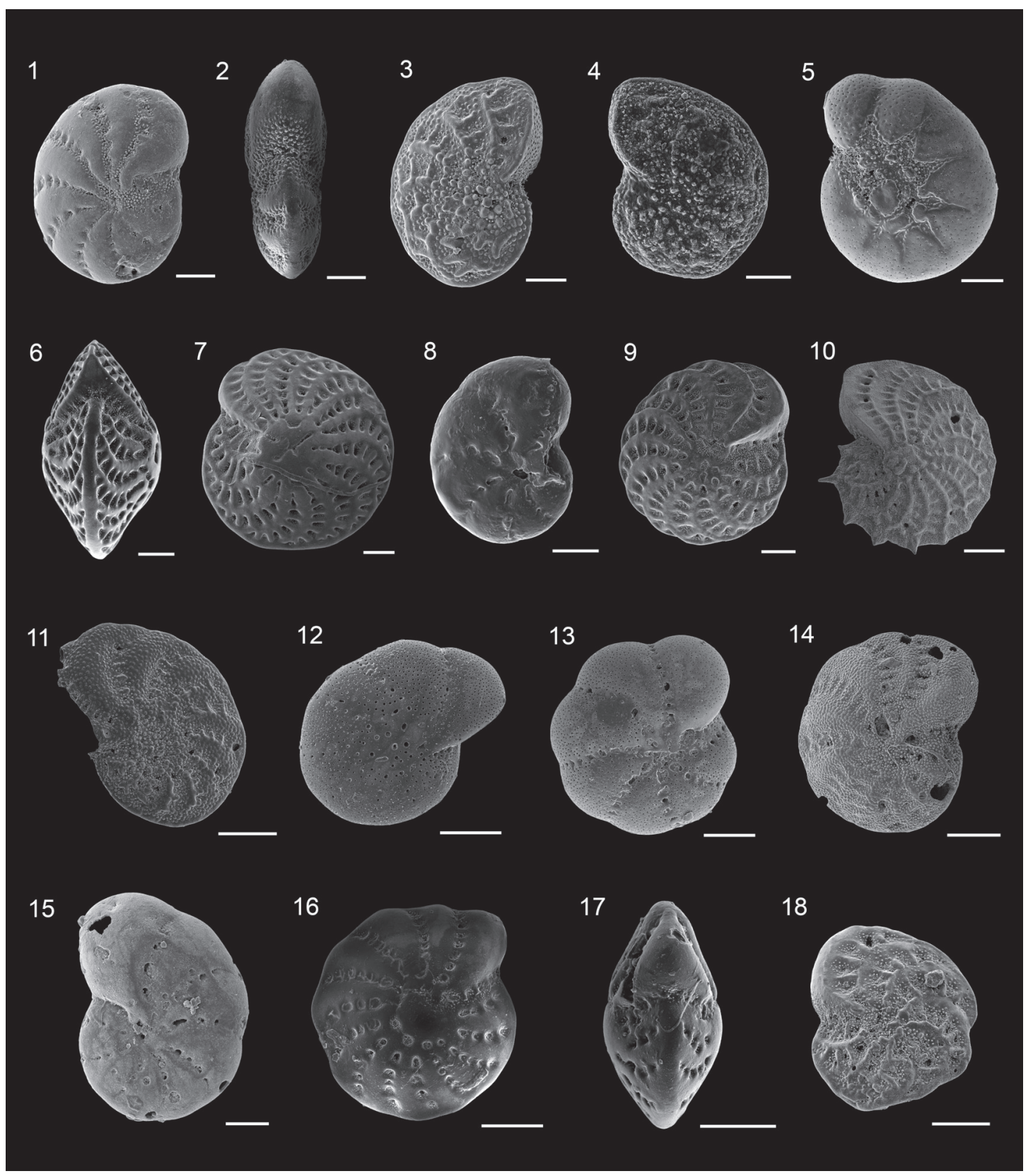

FIGURE 12. 1 Elphidium articulatum (d'Orbigny, 1839), side view, sample STZC 33, ABMC 2016/058; 2 Elphidium articulatum (d'Orbigny, 1839), peripheral view, sample STZC 32, ABMC 2017/010; 3 Elphidium complanatum (d'Orbigny) var. tyrrhenianum Accordi, 1951, side view, sample STZC 29, ABMC 2016/061; 4 Elphidium complanatum (d'Orbigny) var. tyrrhenianum Accordi, 1951, side view, sample STZC 17, ABMC 2017/008; 5 Elphidium granosum (d'Orbigny, 1826), side view, sample STZC 33, ABMC 2016/016; 6 Elphidium crispum (Linnaeus, 1758), peripheral view, sample STZC 30, ABMC 2017/002; 7 Elphidium crispum (Linnaeus, 1758), side view, sample STZC 32, ABMC 2016/034; 8 Elphidium incertum (Williamson, 1858), side view, STZC 29, ABMC 2016/075; 9 Elphidium macellum (Fichtel and Moll, 1798), side view, sample STZC 21, ABMC 2016/044; 10 Elphidium macellum (Fichtel and Moll, 1798), side view sample STZC 34, ABMC 2016/017; 11 Elphidium maioricense Colom, 1942, side view, sample STZC 34, ABMC 2016/019; 12 Elphidium poeyanum (d'Orbigny, 1839) FS form, side view, sample STZC 20, ABMC 2016/ 038; 13 Elphidium poeyanum (d'Orbigny, 1839) DS form, side view, sample STZC 20, ABMC 2016/050; 14 Elphidium pulvereum Todd, 1958, side view, sample STZC 32, ABMC 2016/052; 15 Elphidium advenum (Cushman, 1922), side view, sample STZC 24, ABMC 2016/072; 16 Elphidium punctatum (Terquem, 1878), side view, sample STZC 32, ABMC 2017/011; 17 Elphidium punctatum (Terquem, 1878), peripheral view, sample STZC 32, ABMC 2017/012; 18 Parrellina verriculata (Brady, 1881), side view, sample STZC 20, ABMC 2016/067; Scale bar 1-5, 8, 15 - 50 m; 6, 7, 9-14, 16-18- $100 \mu \mathrm{m}$. 
1980

Elphidium articulatum (d'Orbigny); Boltovskoy, Giussani, Watanabe and Wright, p. 29 , pl. 13, figs. 1-4.

1988 Elphidium articulatum (d'Orbigny); Amore, Barra, Ciampo, Ruggiero Taddei, Russo and Sgarrella, p. 975.

1990 Elphidium articulatum (d'Orbigny); Amore, Barra, Ciampo, Ruggiero Taddei, Russo and Sgarrella, pp. 481-482.

2002 Elphidium articulatum (d'Orbigny); Kaminski, Aku, Box, Hiscott, Filipescu and Al-Salameen, p. 190, pl. 5, figs. 10a-b.

Distribution and remarks. The discrimination between this species and E. williamsoni Haynes, 1973 remains still unclear. $E$. articulatum is generally recorded in paralic and in marine infralittoral waters (Boltovskoy et al., 1980; Sen Gupta et al., 2009b; Rodrigues et al., 2014); common in the fossiliferous samples of La Starza (RA range: $0.38 \%$ to $12.39 \%)$.

Elphidium complanatum (d'Orbigny) var. tyrrhenianum Accordi, 1951

Figure 12.3-4

1951 Elphidium complanatum (d'Orbigny) var. tyrrhenianum Accordi: p. 126, pl. 2, figs. a-b.

1988 Elphidium complanatum (d'Orbigny); Amore, Barra, Ciampo, Ruggiero Taddei, Russo and Sgarrella, p. 975.

1990 Elphidium complanatum (d'Orbigny); Amore, Barra, Ciampo, Ruggiero Taddei, Russo and Sgarrella, pp. 481-482.

2012 Elphidium complanatum (d'Orbigny) var. tyrrhenianum Accordi; Milker and Schmiedl, $p$. 120 , figs. 27.11-12.

Distribution and remarks. The specimens occurring in nine samples (RA range from 0.29 to $9.68 \%$ ) can be referred to the form tyrrhenianum described by Accordi (1951). E. complanatum s.l. is a shelf species, common on sandy bottoms in high energy environment (Milker et al., 2009).

Elphidium crispum (Linnaeus, 1758)

Figure 12.6-7

$1758 \quad$ Nautilus crispum Linnaeus: p. 709.

1988 Elphidium crispum (Linnaeus); Amore, Barra, Ciampo, Ruggiero Taddei, Russo and Sgarrella, p. 975.

1990 Elphidium crispum (Linnaeus); Amore, Barra, Ciampo, Ruggiero Taddei, Russo and Sgarrella, pp. 481-482.

2012 Elphidium crispum (Linnaeus); Milker and Schmiedl, p. 120, figs. 27.13-14.

Distribution and remarks. E. crispum is an infralittoral - upper circalittoral species, epiphyte, associated with carbonate-rich, sandy bottoms
(Avnaim-Katav et al., 2015). Present in the La Starza sediments in almost all the fossiliferous samples (RA from $0.64 \%$ to $9.76 \%$ ).

Elphidium granosum (d'Orbigny, 1826) Figure 12.5

1826 Nonionina granosa d'Orbigny: p. 294, n. 8.

1846 Nonionina granosa d'Orbigny; d'Orbigny, p. 110, pl. 5, figs. 19-20.

1988 Protelphidium granosum (d'Orbigny); Amore, Barra, Ciampo, Ruggiero Taddei, Russo and Sgarrella, p. 975.

1990 Protelphidium granosum (d'Orbigny); Amore, Barra, Ciampo, Ruggiero Taddei, Russo and Sgarrella, pp. 481-482, pl. 1, fig. 6.

2012 Elphidium granosum (d'Orbigny); Milker and Schmiedl, p. 121, figs. 27.17-18.

Distribution and remarks. It is a paralic, infralittoral and subordinately upper circalittoral species, preferring unstressed conditions and tolerating low salinity waters (Jorissen, 1988; Murray, 2006; Phipps et al., 2010). Common in the La Starza sediments. The assemblage of the sample STZC 7 consists of one specimen of $E$. granosum; in the remaining samples the abundance range is $0.82-$ $22.58 \%$.

Elphidium incertum (Williamson, 1858)

Figure 12.8

1858 Polystomella umbilicula Walker var. incertum Williamson: p. 44, pl. 3, fig. 82.

2006 Elphidium incertum (Williamson); Horton and Edwards, p. 76, pl. 4, figs. 18 a-b.

2012 Elphidium incertum (Williamson); Milker and Schmiedl, p. 121, figs. 27.19-20.

Distribution and remarks. Elphidium incertum is a marginal-infralittoral, subordinately circalittoral, species that tolerates dysoxic environment (Alve, 1990; Jorissen et al., 2007); it prefers muddy and sandy muddy bottoms (Polovodova et al., 2009). Very rare at La Starza, the species is present only in the samples STZC $20(0.38 \%)$ and STZC 29 (0.55\%).

Elphidium macellum (Fichtel and Moll, 1798) Figure 12.9-10

1798 Nautilus macellus Fichtel and Moll: p. 66, pl.10, figs. e-g, h-k.

1964 Elphidium macellum (Fichtel and Moll); Rodriquez, p. 115, pl. 6, fig. II.9.

1988 Elphidium macellum (Fichtel and Moll); Amore, Barra, Ciampo, Ruggiero Taddei, Russo and Sgarrella, p. 975.

1990 Elphidium macellum (Fichtel and Moll); Amore, Barra, Ciampo, Ruggiero Taddei, Russo and Sgarrella, pp. 481-482. 
Elphidium macellum (Fichtel and Moll); Milker and Schmiedl, p. 122, figs. 27.21-22.

Distribution and remarks. A marginal to upper circalittoral, mainly infralittoral species which tolerates low salinity waters (Oflaz, 2006; Sen Gupta et al., 2009b; Murray, 2014). Pillet et al. (2013) suggest that the "spinose keel" is not a "species specific feature". Following these authors, the specimens assigned in literature to $E$. aculeatum (d'Orbigny, 1846) generally pertain to $E$. macellum or, alternatively, to E. crispum. Furthermore they suggest that d'Orbigny (1846) described as Polystomella aculeata a spinose form of $E$. macellum. The observed morphological variability supports the statement of Pillet et al. (2012, 2013), leading us to include the aculeate form present in the La Starza sediments (Figure 12.10) in E. macellum.

Common in the La Starza sediments, it occurs in the majority of the fossiliferous samples, with RA ranging from 0.66 to $7.32 \%$.

\section{Elphidium maioricense Colom, 1942}

Figure 12.11

1942 Elphidium maioricensis (sic) Colom: p. 34, pl. 10 , figs. $189-193$.

1993 Elphidium maioricense Colom; Sgarrella and Moncharmont-Zei, p. 229, pl. 21, figs. 10-13.

Distribution and remarks. A shallow, mainly infralittoral, phytophilous species (Sgarrella and Moncharmont, 1993), possibly endemic of the Mediterranean Sea. It occurs at La Starza in five samples (RA range: 0.21\%-7.32\%).

Elphidium poeyanum (d'Orbigny, 1839)

Figure 12.12-13

1839a Polystomella poeyana d'Orbigny: p. 55, pl. 6, figs. 25-26.

1988 Elphidium excavatum (Terquem); Amore, Barra, Ciampo, Ruggiero Taddei, Russo and Sgarrella, p. 975.

1988 "Elphidiononion" cuvilleri (Levy); Amore, Barra, Ciampo, Ruggiero Taddei, Russo and Sgarrella, p. 975.

1990 Elphidium excavatum (Terquem); Amore, Barra, Ciampo, Ruggiero Taddei, Russo and Sgarrella, pp. 481-482, pl. 1, fig. 7.

1990 "Elphidiononion" cuvilleri (Levy); Amore, Barra, Ciampo, Ruggiero Taddei, Russo and Sgarrella, pp. 481-482, pl. 2, fig. 1.

1988 Elphidium poeyanum (d'Orbigny); Jorissen, pp. 116-120, pl. 2 figs. 4, 6; pls. 20-23.

Distribution and remarks. The high morphological variability of this marginal - upper bathyal (Jorissen, 1988; Murray, 2006; Sen Gupta et al., 2009b) species has been thoroughly documented by Jorissen (1988) who observed "a gradual variation between two extreme morphotypes." The first one, named by the author Elphidium poeyanum forma poeyanum, has "a comparatively small number of inflated chambers, depressed sutures and a relatively open umbilicus"; its common presence indicates moderately stressed environmental conditions. The relationship between this morph, that is $E$. poeyanum s.s. (with depressed sutures: DS) and $E$. excavatum Terquem, 1875 is not clear. The second morph, called by Jorissen Elphidium poeyanum forma decipiens (Costa, 1856), shows "a higher number of chambers, flush sutures and an umbilicus filled by glassy material" and is typical of unstressed environment. Within the morph with "flush sutures" (FS form) both E. translucens Natland, 1938 and E. cuvillieri Lévy, 1966 have been included. The assignment of the FS form to Polystomella decipiens by Jorissen is based on the figures of Fornasini (1898) of Costa's material. Unfortunately the Fornasini's pictures are quite different from the original drawings, thus we prefer to avoid using the specific name decipiens for this morphotype.

Due to the different ecological preferences reported we have considered appropriate the discrimination of the two forms, herein named E. poyeanum DS form and $E$. poeyanum $\mathrm{FS}$ form.

Both morphs are common in the La Starza deposits, with $\mathrm{RA}$ respectively, ranging from $0.33 \%$ to $13.14 \%$ (E. poeyanum "FS form"; fig. 12.12) and from $0.51 \%-16.96 \%$ (E. poeyanum "DS form"; fig. 12.13).

Elphidium pulvereum Todd, 1958

Figure 12.14

1958 Elphidium pulvereum Todd: p. 201, pl. 1, figs. 19-20.

1988 Elphidium pulvereum Todd; Amore, Barra, Ciampo, Ruggiero Taddei, Russo and Sgarrella, p. 975.

1990 Elphidium pulvereum Todd; Amore, Barra, Ciampo, Ruggiero Taddei, Russo and Sgarrella, pp. 481-482.

1993 Elphidium pulvereum Todd; Sgarrella and Moncharmont, p. 230, pl. 21, fig. 6.

2001b Elphidium pulvereum Todd; Debenay, Tsakiridis, Soulard, and Grossel, pl. 6, fig. 6.

Distribution and remarks. A stress tolerant, paralic and infralittoral epiphytic species present in circalittoral environment (Sgarrella and Moncharmont, 1993; Debenay et al., 2001b; Debenay and Guillou, 2002); not rare at La Starza with RA ranging from $0.18 \%$ to $9.68 \%$. 
Elphidium punctatum (Terquem, 1878)

Figure 12.16-17

1878 Polystomella punctata Terquem: p. 16, pl. 1, figs. 7a-b.

1964 Elphidium advenum (Cushman); Rodriquez, p. 115, pl. 6, figs. II.10, 12.

1988 Elphidium punctatum (Terquem); Amore, Barra, Ciampo, Ruggiero Taddei, Russo and Sgarrella, p. 975.

1990 Elphidium punctatum (Terquem); Amore, Barra, Ciampo, Ruggiero Taddei, Russo and Sgarrella, pp. 481-482.

1993 Elphidium punctatum (Terquem); Sgarrella and Moncharmont-Zei, p. 230, pl. 21, figs. 34.

2012 Elphidium advenum (Cushman); Milker and Schmiedl, p. 119, figs. 27.7-8.

Distribution and remarks. An infralittoral and subordinately circalittoral species, frequently reported as Elphidium advenum. The comparison of the Terquem's figures with the original pictures of Polystomella advena Cushman, 1922 in edge view suggests they are two distinct species. Elphidium punctatum is present in the majority of the assemblages of La Starza, ranging from $0.29 \%$ to $16.13 \%$

Subfamily NOTOROTALIINAE Hornibrook, 1961 Genus PARRELLINA Thalmann, 1951 Parrellina verriculata (Brady, 1881)

Figure 12.18

1881 Polystomella verriculata Brady: p. 66.

1988 Parrellina verriculata (Brady); Amore, Barra, Ciampo, Ruggiero Taddei, Russo and Sgarrella, p. 975.

1990 Parrellina verriculata (Brady); Amore, Barra, Ciampo, Ruggiero Taddei, Russo and Sgarrella, p. 482.

2012 Parrellina verriculata (Brady); Milker and Schmiedl, p. 122, figs. 27.27-28.

Distribution and remarks. Rare specimens of this infralittoral and upper circalittoral species (Sgarrella and Moncharmont Zei, 1993) occur in Section C.

Class OSTRACODA Latreille, 1802

Subclass PODOCOPA Sars, 1866

Order PODOCOPIDA Sars, 1866

Suborder CYTHEROCOPINA Baird, 1850

Superfamily CYTHEROIDEA Baird, 1850

Family CUSHMANIDEIDAE Puri, 1974

Genus PONTOCYTHERE Dubowsky, 1939

Pontocythere turbida (Müller, 1894)

Figure 13.10
1894

Cytheridea turbida Müller: p. 361, pl., 30, figs. 28, 31-33, 40-45, 47.

1988 Pontocythere turbida (Müller); Amore, Barra, Ciampo, Ruggiero Taddei, Russo and Sgarrella, p. 976.

1990 Pontocythere turbida (Müller); Amore, Barra, Ciampo, Ruggiero Taddei, Russo and Sgarrella, pp. 484-485.

2015 Pontocythere turbida (Müller 1894); Frezza and Di Bella, pl. 1, figs. 17-18.

Distribution and remarks. Pontocythere turbida is commonly recorded in the infralittoral and upper circalittoral of the Mediterranean Sea (Frezza and Di Bella, 2015). At La Starza the species occurs, not rare, in the upper part of the Section C.

Family CYTHERETTIDAE Triebel, 1952

Genus CYTHERETTA Müller, 1894

Cytheretta adriatica Ruggieri, 1952

$1952 \quad$ Cytheretta adriatica Ruggieri: p. 36.

1977 Cytheretta adriatica Ruggieri; Athersuch, pp. 69-78.

Distribution and remarks. An accessory species, typical of the infralittoral zone (Athersuch, 1977), showing low RA in the La Starza assemblages.

Cytheretta subradiosa (Roemer, 1838)

Figure 13.5-6

1838b Cytherina subradiosa Roemer: p. 517, pl. 6, fig. 20.

1976a Cytheretta subradiosa (Roemer); Bonaduce, Ciampo and Masoli, pp. 54-55, pl. 32, figs. 16.

Distribution and remarks. Cytheretta subradiosa occurs in the upper circalittoral and infralittoral zones (Bonaduce et al., 1976a, 1977). In the La Starza assemblages the species shows RA ranges of $0.09 \%-6.98 \%(\mathrm{MNI})$ and $0.35-10.81 \%$ (TNV).

Family CYTHERIDEIDAE Sars, 1925

Genus CYTHERIDEA Bosquet, 1852

Cytheridea neapolitana Kollmann, 1960

Figure 13.8-9

1960 Cytheridea neapolitana Kollmann: p. 152, pl. 7, figs. 7-10, text-figs. 3a-b, d.

1988 Cytheridea neapolitana Kollmann; Amore, Barra, Ciampo, Ruggiero Taddei, Russo and Sgarrella, p. 976.

1990 Cytheridea neapolitana Kollmann; Amore, Barra, Ciampo, Ruggiero Taddei, Russo and Sgarrella, pp. 483, 485, pl. 4, fig. 4.

2015 Cytheridea neapolitana Kollmann; Frezza and Di Bella, pl. 1, figs. 13-14.

Distribution and remarks. A shelf species linked to muddy sediments, rich in organic matter. Cytheridea neapolitana is rare in the uppermost infralitto- 


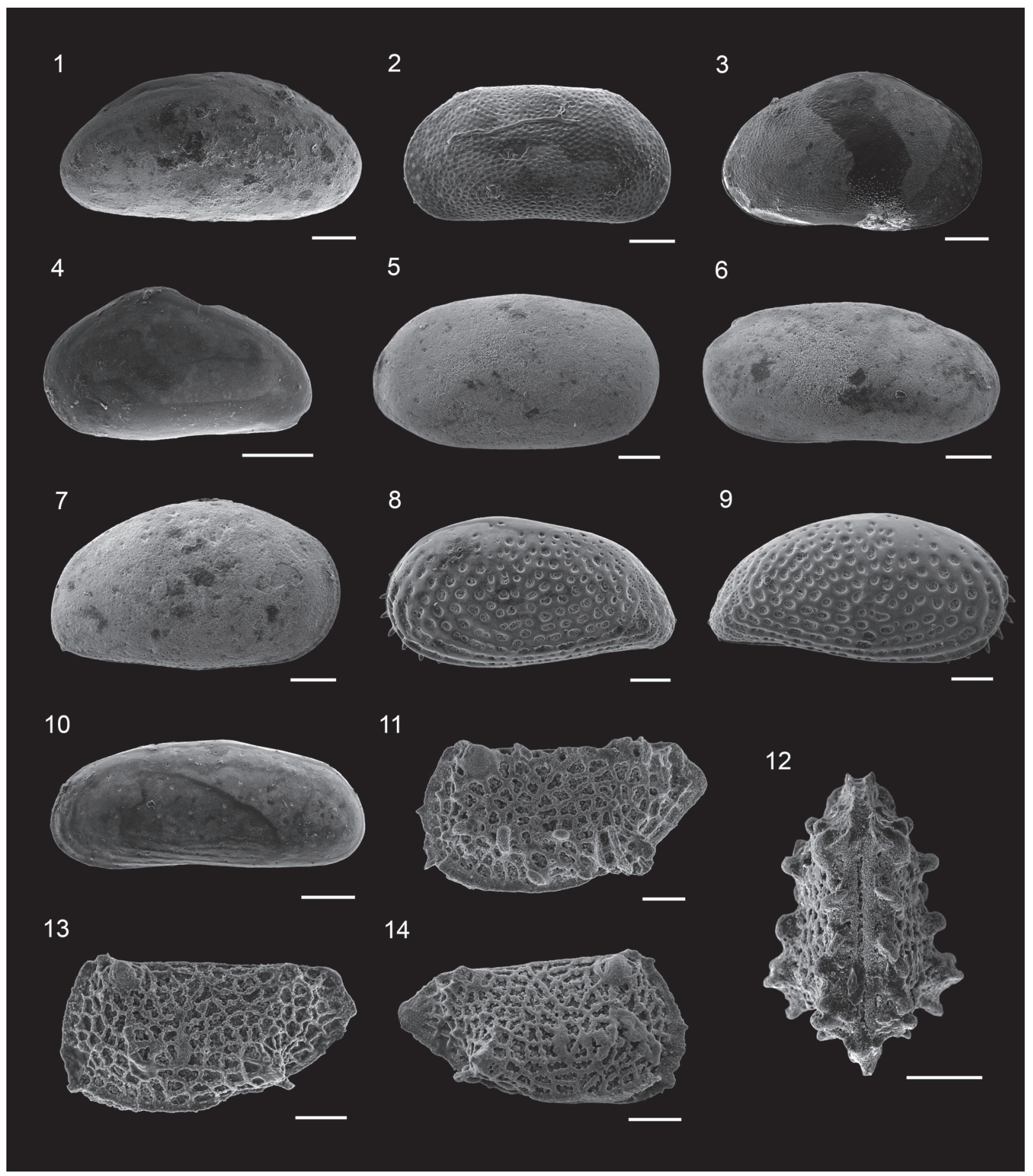

FIGURE 13. 1 Propontocypris ? pellucida (Müller, 1894), right valve, sample STZC 32, ABMC 2017/084; 2 Pseudocandona sarsi (Hartwig, 1899), left valve, sample STZC 29, ABMC 2017/068; 3 Cypris pubera O.F. Müller, 1776, juv, right valve, sample STZC 29, ABMC 2017/070; 4 Cypridopsis sp., left valve, sample STZC 29, ABMC 2017/094; 5 Cytheretta subradiosa (Roemer, 1838), left valve, sample STZC 22, ABMC 2017/072; 6 Cytheretta subradiosa (Roemer, 1838), right valve, sample STZC 22, ABMC 2017/061; 7 Cyprideis torosa (Jones, 1850), right valve, sample STZC 29, ABMC 2017/056; 8 Cytheridea neapolitana Kollmann, 1960, left valve, sample STZC 25, ABMC 2017/036; 9 Cytheridea neapolitana Kollmann, 1960, right valve, sample STZC 33, ABMC 2017/062; 10 Pontocythere turbida (Müller, 1894), left valve, sample STZC 28, ABMC 2017/050; 11 Eucytherura gibbera Müller, 1894, left valve, sample STZC 30, ABMC 2017/020; 12 Eucytherura gibbera Müller, 1894, carapace in dorsal view, sample STZC 28, ABMC 2017/092; 13 Eucytherura mistrettai Sissingh, 1972, left valve, sample STZC 29, ABMC 2017/025; 14 Eucytherura mistrettai Sissingh, 1972, right valve, sample STZC 33, ABMC 2017/077; Scale bar 11, 12, 14 - $50 \mu \mathrm{m} ; 1$ 1-10, 13 - $100 \mu \mathrm{m}$. 
ral zone (0-3 $\mathrm{m} \mathrm{bsl}$ ) and its RA does not exceed $10 \%$ in the depth range $3-25 \mathrm{~m}$ bsl (Aiello, Barra and Parisi, pers. obs.); this species shows its optimum in the depth range 30-125 m bsl (Bonaduce et al., 1976a, 1977; Bakir et al., 2014; Frezza and Di Bella, 2015). The species is common in the La Starza assemblages, with RA ranging from $0.24 \%$ to $31.07 \%$ (MNI) and $0.40 \%$ to $28.33 \%$ (TNV). In the sample STZC 15 the assemblage consists exclusively of $C$. neapolitana.

Family CYTHERURIDAE Müller, 1894

Genus EUCYTHERURA Müller, 1894

Eucytherura gibbera Müller, 1894

Figure 13.11-12

1894 Eucytherura gibbera Müller: p. 307, pl. 19, figs. 21-26; pl. 20, figs. 14, 16, 19; pl. 21, figs. 1-2.

1977 Eucytherura gibbera Müller; Bonaduce, Masoli and Pugliese, pl. 4, fig. 2.

1988 Eucytherura gibbera Müller; Amore, Barra, Ciampo, Ruggiero Taddei, Russo and Sgarrella, p. 976.

1990 Eucytherura gibbera Müller; Amore, Barra, Ciampo, Ruggiero Taddei, Russo and Sgarrella, p. 483

Distribution and remarks. A rare shelf species (Müller, 1894; Bonaduce et al., 1977; Yassini, 1979) occurring in three samples of the Section C.

Eucytherura mistrettai Sissingh, 1972

Figure 13.13-14

1972 Eucytherura mistrettai Sissingh: p. 140.

1976a Eucytherura mistrettai Sissingh; Bonaduce, Ciampo and Masoli, pl. 49, figs. 1-7.

Distribution and remarks. E. mistrettai is a mainly circalittoral species generally recorded below $70 \mathrm{~m}$ bsl (Bonaduce et al., 1976a, 1977). Rare in the La Starza section, it is present with few valves in two samples.

Genus HEMICYTHERURA Elofson, 1941

Hemicytherura defiorei Ruggieri, 1953

Figure 14.1

1953 Hemicytherura defiorei Ruggieri: p. 50, figs. 8-8a, 11-13.

1988 Hemicytherura defiorei Ruggieri; Amore, Barra, Ciampo, Ruggiero Taddei, Russo and Sgarrella, p. 976.

1990 Hemicytherura defiorei Ruggieri; Amore, Barra, Ciampo, Ruggiero Taddei, Russo and Sgarrella, pp. 483, 485.

2004 Hemicytherura defiorei Ruggieri; Aiello and Szczechura, pp. 39-40, pl. 9, figs. 3-4.

Distribution and remarks. An infralittoral - upper circalittoral species not recorded below $108 \mathrm{~m}$ bsl (extended references in Aiello and Szczechura, 2004). Rare specimens are present in the uppermost part of Section C.

Hemicytherura videns (Müller, 1894)

1894 Cytheropteron videns Müller: p. 303, pl. 20, figs 2, 8; pl. 21, figs. 15-16, 18.

1988 Hemicytherura videns (Müller); Amore, Barra, Ciampo, Ruggiero Taddei, Russo and Sgarrella, p. 976

1990 Hemicytherura videns (Müller); Amore, Barra, Ciampo, Ruggiero Taddei, Russo and Sgarrella, p. 483.

2004 Hemicytherura videns (Müller); Aiello and Szczechura, p. 40, pl. 9, figs. 1-2.

Distribution and remarks. A phytophilous, mainly infralittoral species (extended references in Aiello and Szczechura, 2004), rare both in Sections B and $\mathrm{C}$.

Genus MICROCYTHERURA Müller, 1894

Microcytherura fulva (Brady and Robertson, 1874) Figure 14.2-3

1874 Cytherura fulva Brady and Robertson: p. 116, pl. 4, figs. 1-5.

1976a Microcytherura fulva (Brady and Robertson); Bonaduce, Ciampo and Masoli, p. 89, pl. 57, figs. 9-13.

1997 Microcytherura fulva (Brady and Robertson); Barra, p. 75, pl. 1, fig. 8.

Distribution and remarks. An accessory species, living in the infralittoral and upper circalittoral zone (Bonaduce et al., 1976a; Rosenfeld, 1977; Aiello et al., 2006), occurring at La Starza in the samples STZC 29 and STZC 31.

Genus PSEUDOCYTHERURA Dubowsky, 1939

Pseudocytherura strangulata Ruggieri, 1991

Figure 14.10-11

1976a Pseudocytherura calcarata (Seguenza); Bonaduce, Ciampo and Masoli, pp. 90-91, pl. 50, figs. 7-12. (non Cytheropteron calcaratum Seguenza, 1880).

1991 Pseudocytherura strangulata Ruggieri: pp. 68-69.

Distribution and remarks. An infralittoral and circalittoral species (Bonaduce et al. 1976a; Aiello et al., 2006) present only in the sample STZC 27.

Genus SEMICYTHERURA Wagner, 1957

Semicytherura alifera Ruggieri, 1959

Figure 14.5-6

1894 Cytherura alata Müller: p. 288, pl. 18, figs. 1, 7-8; pl. 19, fig. 9.

1959 Semicytherura alifera Ruggieri; p. 204 (new name). 


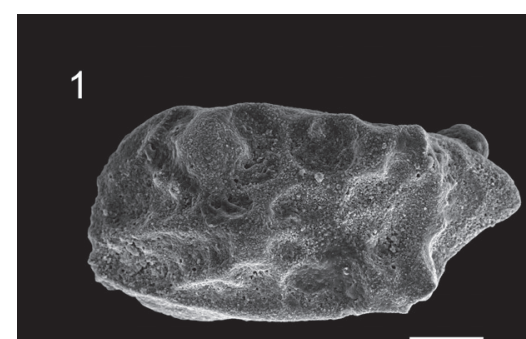

4

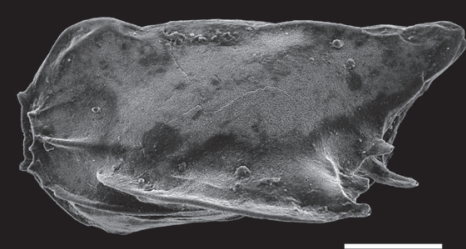

7

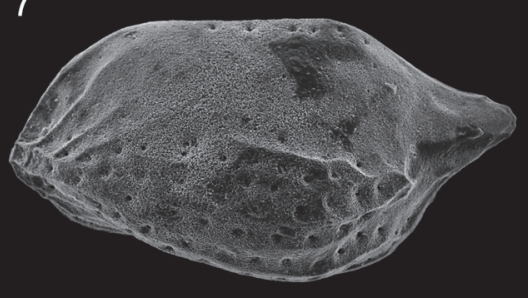

10

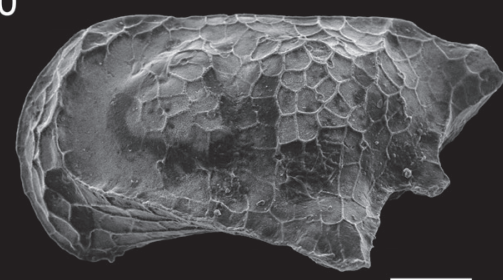

12

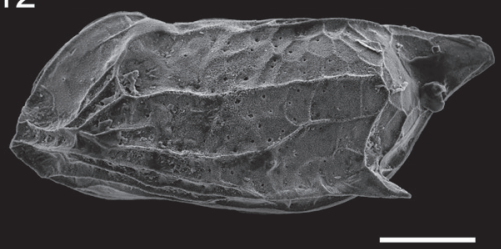

2

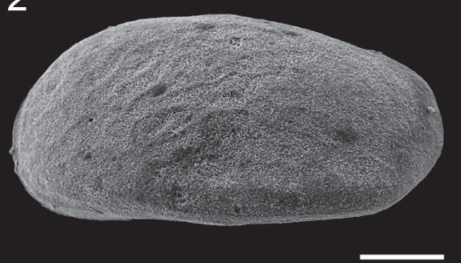

5

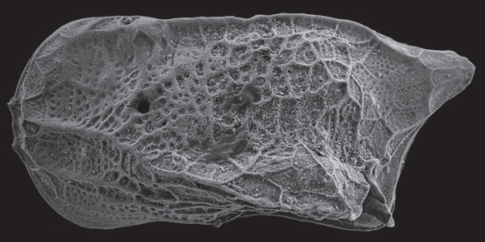

8

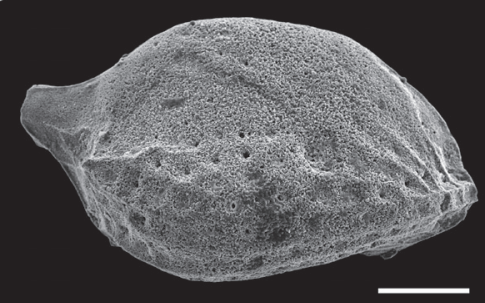

3

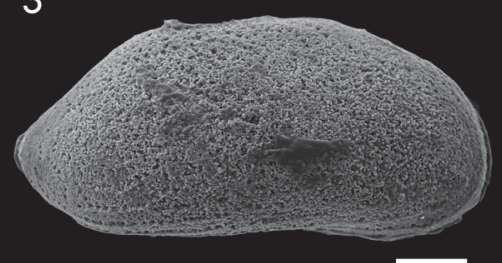

6

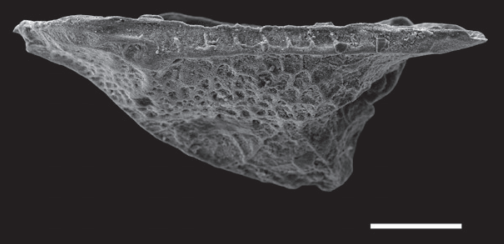

11

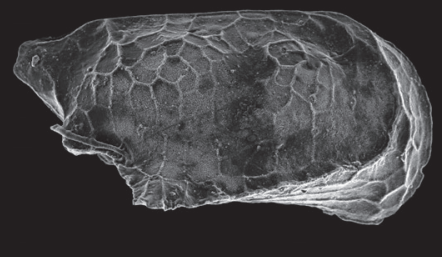

9

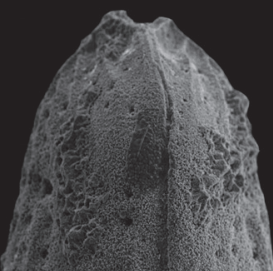

13

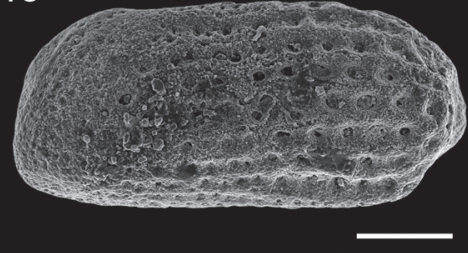

14

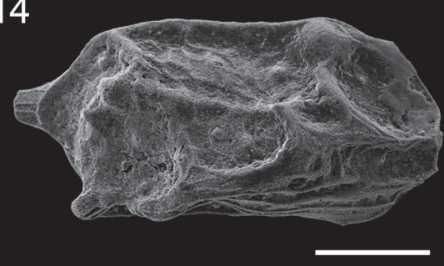

FIGURE 14. 1 Hemicytherura defiorei Ruggieri, 1953, left valve, sample STZC 34, ABMC 2017/091; 2 Microcytherura fulva (Brady and Robertson, 1874), left valve, sample STZC 31, ABMC 2017/078; 3 Microcytherura fulva (Brady and Robertson, 1874), right valve, sample STZC 29, ABMC 2017/076; 4 Semicytherura paradoxa (Müller, 1894), left valve, sample STZC 27, ABMC 2017/035; 5 Semicytherura alifera Ruggieri, 1959, left valve, sample STZC 23, ABMC 2017/ 041; 6 Semicytherura alifera Ruggieri, 1959, left valve in dorsal view, sample STZC 23, ABMC 2017/041; 7 Semicytherura incongruens (Müller, 1894), left valve, sample STZC 28, ABMC 2017/034; 8 Semicytherura incongruens (Müller, 1894), right valve, sample STZC 21, ABMC 2017/043; 9 Semicytherura incongruens (Müller, 1894), carapace in dorsal view, sample STZC 32, ABMC 2017/067; 10 Pseudocytherura strangulata Ruggieri, 1991, left valve, sample STZC 27, ABMC 2017/053; 11 Pseudocytherura strangulata Ruggieri, 1991, juv, right valve, sample STZC 27, ABMC 2017/015; 12 Semicytherura ruggierii (Pucci, 1955), left valve, sample STZC 27, ABMC 2017/044; 13 Semicytherura sulcata (Müller, 1894), left valve, sample STZC 33, ABMC 2017/024; 14 Semicytherura dispar (Müller, 1894), right valve, sample STZC 32, ABMC 2017/057; Scale bar 1-3 - $50 \mu \mathrm{m}$; 4-14 - $100 \mu \mathrm{m}$. 
1976a Semicytherura alifera Ruggieri; Bonaduce, Ciampo and Masoli, p. 70, pl. 44, figs. 3-9.

1988 Semicytherura alifera Ruggieri; Amore, Barra, Ciampo, Ruggiero Taddei, Russo and Sgarrella, p. 977.

1990 Semicytherura alifera Ruggieri; Amore, Barra, Ciampo, Ruggiero Taddei, Russo and Sgarrella, pp. 484-485.

Distribution and remarks. Rare shells of Semicytherura alifera, an infralittoral and upper circalittoral species (Bonaduce et al., 1976a, 1977, 1988; Breman, 1976), occur in three samples of Section C.

Semicytherura dispar (Müller, 1894)

Figure 14.14

1894 Cytherura dispar Müller: p. 293, pl. 19, fig. 16; pl. 20, figs. 1, 6-7.

1976a Semicytherura dispar (Müller); Bonaduce, Ciampo and Masoli, pp. 71-72, pl. 40, figs. 69.

1988 Semicytherura dispar (Müller); Amore, Barra, Ciampo, Ruggiero Taddei, Russo and Sgarrella, p. 977.

1990 Semicytherura dispar (Müller); Amore, Barra, Ciampo, Ruggiero Taddei, Russo and Sgarrella, p. 484.

Distribution and remarks. Semicytherura dispar lives from the upper part of the infralittoral zone up to the upper circalittoral (Barbeito-Gonzalez, 1971; Uffenorde, 1972; Bonaduce et al., 1976a, 1977, 1988; Aiello et al., 2006). Rare and scattered valves have been recorded in Section C.

Semicytherura incongruens (Müller, 1894)

Figure 14.7-9

1894 Cytherura incongruens Müller: p. 296, pl. 17, figs. 2, 7-8; pl. 19, fig. 7.

1976a Semicytherura incongruens (Müller, 1894); Bonaduce, Ciampo and Masoli, p. 72, pl. 40, figs. 12-15.

1988 Semicytherura incongruens (Müller); Amore, Barra, Ciampo, Ruggiero Taddei, Russo and Sgarrella, p. 977.

1990 Semicytherura incongruens (Müller); Amore, Barra, Ciampo, Ruggiero Taddei, Russo and Sgarrella, pp. 484-485.

Distribution and remarks. $S$. incongruens is a shelf species, characteristic of the infralittoral and upper circalittoral zone of the Mediterranean (Uffenorde, 1972; Bonaduce et al., 1976a, 1977, 1988; Frezza and Di Bella, 2015). The species is well represented in the fossiliferous levels of the La Starza succession, reaching a maximum RA value of $53.85 \%(\mathrm{MNI})$.
Semicytherura paradoxa (Müller, 1894)

Figure 14.4

1894 Cytherura paradoxa Müller: p. 294, pl. 17, figs. 3, 9; pl. 19, fig. 12.

1976a Semicytherura paradoxa (Müller); Bonaduce, Ciampo and Masoli, p. 74, pl. 44, figs. 1-2.

1988 Semicytherura paradoxa (Müller); Amore, Barra, Ciampo, Ruggiero Taddei, Russo and Sgarrella, p. 977.

1990 Semicytherura paradoxa (Müller); Amore, Barra, Ciampo, Ruggiero Taddei, Russo and Sgarrella, p. 484.

Distribution and remarks. An infralittoral species (Barbeito-Gonzalez, 1971; Uffenorde, 1972; Bonaduce et al., 1976a; Aiello et al., 2006) rare at La Starza, where it has been recorded in two samples of Section C.

Semicytherura rara (Müller, 1894)

1894 Cytherura rara Müller: p. 299, pl. 17, figs. 1415; pl. 19, fig. 20.

1976a Semicytherura rara (Müller); Bonaduce, Ciampo and Masoli, p. 76, pl. 46, figs. 8-9.

1988 Semicytherura rara (Müller); Amore, Barra, Ciampo, Ruggiero Taddei, Russo and Sgarrella, p. 977.

1990 Semicytherura rara (Müller); Amore, Barra, Ciampo, Ruggiero Taddei, Russo and Sgarrella, p. 484.

Distribution and remarks. Some poor preserved valves of this shelf species (Bonaduce et al., 1976a, 1977, 1988; Aiello et al., 2006) have been recorded in two samples of Section C.

Semicytherura rarecostata Bonaduce, Ciampo and Masoli, 1976

1976a Semicytherura rarecostata Bonaduce, Ciampo and Masoli: pp. 76-77, pl. 46, figs. 10-12.

1988 Semicytherura rarecostata Bonaduce, Ciampo and Masoli; Amore, Barra, Ciampo, Ruggiero Taddei, Russo and Sgarrella, p. 977.

1990 Semicytherura rarecostata Bonaduce, Ciampo and Masoli; Amore, Barra, Ciampo, Ruggiero Taddei, Russo and Sgarrella, p. 484.

Distribution and remarks. A shelf species showing its optimum in upper circalittoral waters (Bonaduce et al., 1976a; Aiello, Barra and Parisi, pers. obs.). S. rarecostata is present in Section $C$ in three samples, displaying low RA.

Semicytherura ruggierii (Pucci, 1955)

Figure 14.12

1955 Cytherura ruggierii Pucci: p. 167, pl. 1, figs. 34; text-fig. 1.

1976a Semicytherura ruggierii (Pucci); Bonaduce, Ciampo and Masoli, p. 79, pl. 38, figs. 1-10. 
1988 Semicytherura ruggierii (Pucci); Amore, Barra, Ciampo, Ruggiero Taddei, Russo and Sgarrella, p. 977.

1990 Semicytherura ruggierii (Pucci); Amore, Barra, Ciampo, Ruggiero Taddei, Russo and Sgarrella, pp. 484, 485.

Distribution and remarks. Semicytherura ruggierii is a shelf species, present up to the upper bathyal (Uffenorde, 1972; Bonaduce et al., 1976a, $1977,1988)$, very rare in the uppermost part of the infralittoral zone (Aiello et al., 2006; Perçin-Paçal and Balkis, 2012). The species is not rare in Section $\mathrm{C}$, reaching a $\mathrm{RA}$ of $13.27 \%(\mathrm{MNI})$.

Semicytherura sulcata (Müller, 1894)

Figure 14.13

1894 Cytherura sulcata Müller: p. 297, pl. 17, figs. 4, 10; pl. 19, fig. 19.

1976a Semicytherura sulcata (Müller); Bonaduce, Ciampo and Masoli, pp. 80-81, pl. 39, figs. 610.

1988 Semicytherura sulcata (Müller); Amore, Barra, Ciampo, Ruggiero Taddei, Russo and Sgarrella, p. 977.

1990 Semicytherura sulcata (Müller); Amore, Barra, Ciampo, Ruggiero Taddei, Russo and Sgarrella, pp. 484-485.

Distribution and remarks. An infralittoral and upper circalittoral species (Bonaduce et al., 1976a, 1977, 1988; Aiello et al., 2006; Balassone et al., 2016; Mangoni et al., 2016) not rare in the upper part of Section C with a maximum value of $11.49 \%$ (MNI).

Family EUCYTHERIDAE Puri, 1954 Genus EUCYTHERE Brady, 1868 Eucythere curta Ruggieri, 1975 Figure 15.1

1975 Eucythere curta Ruggieri: p. 433, fig. 6.

1976a Eucythere curta Ruggieri; Bonaduce, Ciampo and Masoli, p. 63, pl. 37, figs. 9-13.

1988 Eucythere curta Ruggieri; Amore, Barra, Ciampo, Ruggiero Taddei, Russo and Sgarrella p. 976.

1990 Eucythere curta Ruggieri; Amore, Barra, Ciampo, Ruggiero Taddei, Russo and Sgarrella, pp. 483, 485.

Distribution and remarks. A mainly circalittoral species, very rare in infralittoral waters (Ruggieri, 1975; Bonaduce et al., 1976a, 1977, 1988; Aiello et al., 2006). Present in three samples of Section C with low RA values.

Family HEMICYTHERIDAE Puri, 1953

Genus AURILA Pokorný, 1955

Aurila convexa (Baird, 1850)
1850 Cythere convexa Baird: p. 174, pl. 21, fig. 3.

1989 Aurila convexa (Baird); Athersuch, Horne and Whittaker, pp. 157-158, figs. 62a-f, pl. 5, fig. 1.

Distribution and remarks. Aurila convexa is an infralittoral and upper circalittoral phytal species (Bonaduce et al., 1976a, 1977; Athersuch et al., 1989). At La Starza few specimens have been recorded.

Aurila prasina Barbeito-Gonzalez, 1971

1971 Aurila prasina Barbeito-Gonzalez: p. 277, pl. 12, figs. 1a-3a; pl. 46, figs. 11-12.

1976a Aurila prasina Barbeito-Gonzalez; Bonaduce, Ciampo and Masoli, pl. 20, figs. 1-7.

Distribution and remarks. Rare valves of this upper infralittoral species (Barbeito-Gonzalez, 1971; Bonaduce et al., 1976a; Aiello et al., 2006) are present in Section C.

Genus UROCYTHEREIS Ruggieri, 1950 Urocythereis ilariae Aiello, Barra and Parisi, 2016 $2016 \quad$ Urocythereis ilariae Aiello, Barra and Parisi: pp. 19-21, figs. 2B; 3G-H; 4G-H; 5G-H; 6G-H; 14; 18A-J; 19A-C, E-J.

Distribution and remarks. Urocythereis ilariae is an infralittoral species (Aiello et al., 2016) uncommon at La Starza, where is generally present with low RA.

Urocythereis margaritifera (Müller, 1894)

1894 Cythereis margaritifera Müller: p. 368, pl. 32, figs. $26,29,32$, 35-37.

2016 Urocythereis margaritifera (Müller); Aiello, Barra and Parisi, pp. 21-23, figs. 2A; 3A-F; 4A-F; 5A-F; 6A-F; 16A-K; 17A-J; 19D.

Distribution and remarks. A species characteristic of the infralittoral sandy bottoms of the Mediterranean, displaying a high morphological variability (Aiello et al., 2016). Relatively uncommon at La Starza, shows a maximum RA value of $9.01 \%$ (TNV).

Family KRITHIDAE Mandelstam, 1958 Genus PSEUDOPSAMMOCYTHERE Carbonnel, 1966

Pseudopsammocythere reniformis (Brady, 1868) Figure 15.2

1868 Paradoxostoma (?) reniforme Brady: p. 224, pl. 15, figs. 1-2.

1894 Krithe reniformis (Brady); Müller, pp. 358-359, pl. 28, fig. 24; pl. 30, figs. 1, 3-16, 22-23.

1976 Pseudopsammocythere reniformis (Brady); Breman, p. 55, pl. 11, fig. 26.

Distribution and remarks. This mainly infralittoral species (Uffenorde, 1972; Breman, 1976; Bonaduce et al., 1988) is continuously present in the 

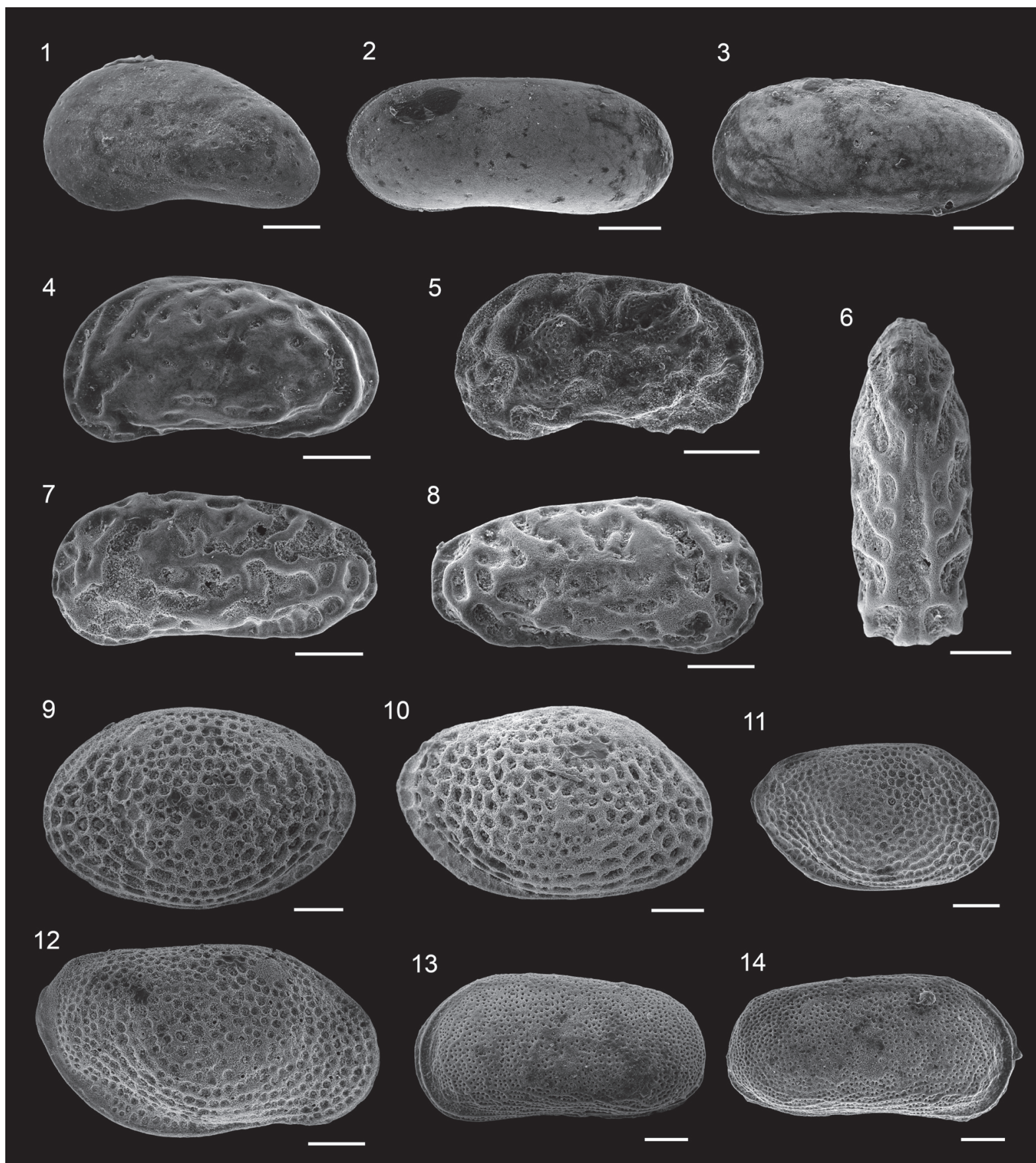

13

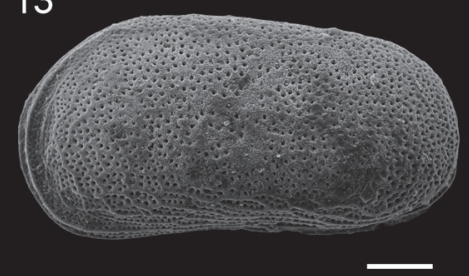

14

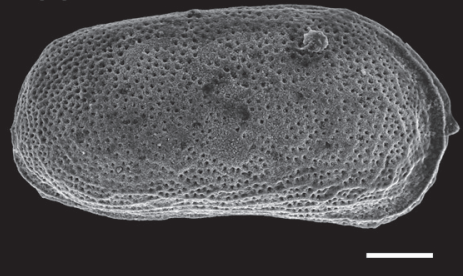

FIGURE 15. 1 Eucythere curta Ruggieri, 1975, left valve, sample STZC 25, ABMC 2017/058; 2 Pseudopsammocythere reniformis (Brady, 1868), left valve, sample STZC 10, ABMC 2017/017; 3 Leptocythere ramosa (Rome, 1942), left valve, sample STZC 27, ABMC 2017/033; 4 Callistocythere badia (Norman, 1862), left valve, sample STZC 27, ABMC 2017/048; 5 Callistocythere littoralis (Müller, 1894), left valve, sample STZC 34, ABMC 2017/016; 6 Callistocythere flavidofusca (Ruggieri, 1950), carapace in dorsal view, sample STZC 19, ABMC 2017/074; 7 Callistocythere flavidofusca (Ruggieri, 1950), left valve, sample STZC 32, ABMC 2017/019; 8 Callistocythere flavidofusca (Ruggieri, 1950), right valve, sample STZC 28, ABMC 2017/059; 9 Loxoconcha ovulata (Costa, 1863), left valve, sample STZC 30, ABMC 2017/038; 10 Loxoconcha ovulata (Costa, 1863), right valve, sample STZC 29, ABMC 2017/060; 11 Loxoconcha ovulata (Costa, 1863), juv, right valve, sample STZC 33, ABMC 2017/018; 12 Loxoconcha gibberosa Terquem, 1878, right valve, sample STZC 30, ABCM 2017/030; 13 Cytheromorpha nana Bonaduce, Ciampo and Masoli, 1976, left valve, sample STZC 28, ABMC 2017/069; 14 Cytheromorpha nana Bonaduce, Ciampo and Masoli, 1976, right valve, sample STZC 31, ABMC 2017/031; Scale bar 13, $14-50 \mu \mathrm{m} ; 1-12-100 \mu \mathrm{m}$. 
Section C from the sample STZC 19 to the uppermost level, with RA ranging from $0.85 \%$ to $15.46 \%$ (MNI) and from $0.9 \%$ to $14.29 \%$ (TNV).

Family LEPTOCYTHERIDAE Hanai, 1957 Genus LEPTOCYTHERE Sars, 1925

Leptocythere macella Ruggieri, 1975

1975 Leptocythere macella Ruggieri: p. 431, fig. 4.

1976a Leptocythere macella Ruggieri; Bonaduce, Ciampo and Masoli, pp. 32-33, pl. 18, figs. 15, text-figs. 12-15.

1988 Leptocythere macella Ruggieri; Amore, Barra, Ciampo, Ruggiero Taddei, Russo and Sgarrella, p. 976.

1990 Leptocythere macella Ruggieri; Amore, Barra, Ciampo, Ruggiero Taddei, Russo and Sgarrella, p. 483.

Distribution and remarks. Some poorly preserved shells of $L$. macella, an infralittoral-circalittoral species (Bonaduce et al., 1976a, 1977, 1988), occur in two samples of La Starza succession.

Leptocythere ramosa (Rome, 1942)

Figure 15.3

1942 Cythere ramosa Rome: p. 22, figs. 21-22; pl. 2, fig. 7.

1988 Leptocythere ramosa (Rome); Amore, Barra, Ciampo, Ruggiero Taddei, Russo and Sgarrella, p. 976

1990 Leptocythere ramosa (Rome); Amore, Barra, Ciampo, Ruggiero Taddei, Russo and Sgarrella, p. 483.

2003 Leptocythere ramosa (Rome); Guernet, Lemeille, Sorel, Bourdillon, Berge-Thierry and Manakou, pp. 77, 79, pl. 1, figs. 3-4.

2015 Leptocythere ramosa (Rome); Frezza and Di Bella, pl. 1, figs. 1-2.

Distribution and remarks. An infra-circalittoral species (Guernet et al., 2003; Frezza and Di Bella, 2015) common at La Starza in Section C, showing a maximum $\mathrm{RA}$ of $19.38 \%$ (MNI).

Genus CALLISTOCYTHERE Ruggieri, 1953

Callistocythere badia (Norman, 1862)

Figure 15.4

1862 Cythere badia Norman: p. 48, pl. 3, figs. 1315.

1977 Callistocythere badia (Norman); Athersuch and Whittaker, pp. 53-58.

1989 Callistocythere badia (Norman); Athersuch, Horne and Whittaker, pp. 110-111, pl. 2, fig. 5.

Distribution and remarks. The species, also cited as C. folliculosa Bonaduce, Ciampo and Masoli, 1976a, has been recorded in very shallow waters of the Eastern Atlantic and Mediterranean (Ather- such et al., 1989; Barra, 1997; Cabral and Loureiro, 2013). C. badia is uncommon at La Starza, occurring in seven samples of Section $C$ with low RA.

Callistocythere flavidofusca (Ruggieri, 1950)

Figure 15.6-8

1950 Leptocythere flavidofusca Ruggieri: p. 46, pl. 1, figs. 6-7.

1976a Callistocythere flavidofusca (Ruggieri); Bonaduce, Ciampo and Masoli, p. 36, pl. 12, figs. 6-11.

1988 Callistocythere flavidofusca (Ruggieri); Amore, Barra, Ciampo, Ruggiero Taddei, Russo and Sgarrella, p. 976.

1990 Callistocythere flavidofusca (Ruggieri); Amore, Barra, Ciampo, Ruggiero Taddei, Russo and Sgarrella, pp. 483, 485.

2008 Callistocythere flavidofusca (Ruggieri); Faranda and Gliozzi, p. 220, pl. 3, figs. 1-2.

Distribution and remarks. An upper shelf, mostly infralittoral, species, not recorded below $120 \mathrm{mbls}$ (Bonaduce et al., 1976a, 1988). Present in Section $\mathrm{C}$, relatively rare.

Callistocythere littoralis (Müller, 1894) Figure 15.5

1894 Cythere littoralis sp. nov. Müller: p. 353, pl. 28, fig. 18.

1980 Callistocythere littoralis (Müller); Athersuch and Whittaker, pp. 61-66.

1988 Callistocythere littoralis (Müller); Amore, Barra, Ciampo, Ruggiero Taddei, Russo and Sgarrella, p. 976.

1989 Callistocythere littoralis (Müller); Athersuch, Horne and Whittaker, p. 108, fig. 41, pl. 2, fig. 4.

1990 Callistocythere littoralis (Müller); Amore, Barra, Ciampo, Ruggiero Taddei, Russo and Sgarrella, pp. 483, 485.

Distribution and remarks. An infralittoral to upper circalittoral phytal species, occurring in Section C in two samples, with low RA values.

Family LOXOCONCHIDAE Sars, 1925

Genus LOXOCONCHA Sars, 1866

Loxoconcha gibberosa Terquem, 1878

Figure 15.12

1878 Loxoconcha gibberosa Terquem: p. 95, pl. 10, figs. 20a-e.

1976a Loxoconcha gibberosa Terquem; Bonaduce, Ciampo and Masoli, p. 108, pl. 64, figs. 1-7.

1988 Loxoconcha gibberosa Terquem; Amore, Barra, Ciampo, Ruggiero Taddei, Russo and Sgarrella, p. 976 . 
1990

Loxoconcha gibberosa Terquem; Amore, Barra, Ciampo, Ruggiero Taddei, Russo and Sgarrella, pp. 483, 485.

2005 Loxoconcha gibberosa Terquem; Schneider, Witt and Yigitba?, p. 94, pl. 2, fig. 2.

Distribution and remarks. A shelf, mainly infralittoral species (Bonaduce et al., 1988; Aiello et al., 2006), very rare in the La Starza sediments, occurring only in the sample STZC $30(\mathrm{MNI}=3.42 \%$; $\mathrm{TNV}=1.78 \%$ ).

Loxoconcha ovulata (Costa, 1853)

Figure 15.9-11

1853c Cythere ovulata Costa: p. 181, pl. 16, fig. 7.

1979b Loxoconcha ovulata (Costa); Athersuch, pp. 141-150.

1988 Loxoconcha tumida Brady; Amore, Barra, Ciampo, Ruggiero Taddei, Russo and Sgarrella, p. 976.

1990 Loxoconcha tumida Brady; Amore, Barra, Ciampo, Ruggiero Taddei, Russo and Sgarrella, pp. 483, 485.

Distribution and remarks. L. ovulata is a mainly infralittoral, subordinately upper circalittoral species (Barra, 1997; Aiello et al., 2006; Frezza and Di Bella, 2015), tolerant to stressed environment (Salvi et al., 2015) recorded both in Sections B and $\mathrm{C}(\mathrm{MNI}=$ from $0.48 \%$ to $18.60 \%$; $\mathrm{TNV}=$ from $0.40 \%$ to $17.12 \%)$.

Genus CYTHEROMORPHA Hirschmann, 1909

Cytheromorpha nana Bonaduce, Ciampo and Masoli, 1976

Figure 15.13-14

1976a Cytheromorpha nana Bonaduce, Ciampo and Masoli: p. 114, pl. 70, figs. 9-11.

Distribution and remarks. C. nana has been recorded in the depth range 19-111 mbsl (Bonaduce et al., 1976a). Uncommon at La Starza is present in six samples with a maximum RA of $2.77 \%(\mathrm{MNI})$.

Genus ELOFSONIA Wagner, 1957

"Elofsonia" minima (Bonaduce, Ciampo and Masoli, 1976)

Figure 16.1-2

1976a «Bythocythere minima» Bonaduce, Ciampo and Masoli: pp. 114-115, pl. 78, figs. 7-11.

1988 Bythocythere minima Bonaduce, Ciampo and Masoli; Bonaduce, Masoli and Pugliese, p. 455.

1988 «Bythocythere minima» Bonaduce, Ciampo and Masoli; Amore, Barra, Ciampo, Ruggiero Taddei, Russo and Sgarrella, p. 976.
1990

«Bythocythere minima» Bonaduce, Ciampo and Masoli; Amore, Barra, Ciampo, Ruggiero Taddei, Russo and Sgarrella, p. 483.

2006 "Elofsonia" minima (Bonaduce, Ciampo and Masoli); Aiello, Barra, Coppa, Valente and Zeni, tab. 3.

Distribution and remarks. An infralittoral species (Bonaduce et al., 1976a; Bonaduce et al., 1988; Aiello et al., 2006) present at La Starza in three samples, with RA ranging from $0.24 \%-2.77 \%$ (MNI) and from $0.60 \%$ to $0.81 \%$ (TNV). Some valves fit well with the original figures (Figure 16.1) whereas other specimens show a slightly different outline and ornamentation (Figure 16.2) maybe due to sexual dimorphism. Since intraspecific variability of this species is barely documented in literature, we have assigned all this forms to "Elofsonia" minima, aware of the need of well preserved material to define its taxonomy.

Genus PALMOCONCHA Swain and Gilby, 1974 Palmoconcha turbida (Müller, 1912)

Figure 16.3

1912 Loxoconcha turbida Müller: p. 308.

2015 Palmoconcha turbida (Müller); Frezza and Di Bella, pl. 1, figs. 15-16.

Distribution and remarks. A shelf species, tolerant to low oxic waters (Bodergat et al., 1998), mainly living in infralittoral and upper circalittoral waters (Bonaduce et al., 1977; Frezza and Di Bella, 2015). At La Starza it has been recorded in Section C from the sample 20 to the sample 32 with a RA ranging from $1.75 \%$ to $8.30 \%$ (MNI) and from $1.19 \%$ to $5.5 \%$ (TNV).

Genus SAGMATOCYTHERE Athersuch, 1976

Sagmatocythere versicolor (Müller, 1894)

Figure 16.4-5

1894 Loxoconcha versicolor Müller: p. 346, pl. 27, fig. 4; pl. 28, figs. 5, 10.

1976a Loxoconcha versicolor Müller; Bonaduce, Ciampo and Masoli, p. 111, pl. 65, figs. 1-8.

1988 Loxoconcha versicolor Müller; Amore, Barra, Ciampo, Ruggiero Taddei, Russo and Sgarrella, p. 976.

1990 Loxoconcha versicolor Müller; Amore, Barra, Ciampo, Ruggiero Taddei, Russo and Sgarrella, pp. 483, 485.

2008 Sagmatocythere versicolor (Müller); Faranda and Gliozzi, p. 223, pl. 9, fig. 13.

Distribution and remarks. A shelf species generally showing its maximum abundance in lower infralittoral - upper circalittoral zone (Bonaduce et al., 1976a, 1977, 1988; Aiello et al., 2006; Frezza and Di Bella, 2015). At La Starza S. versicolor is 

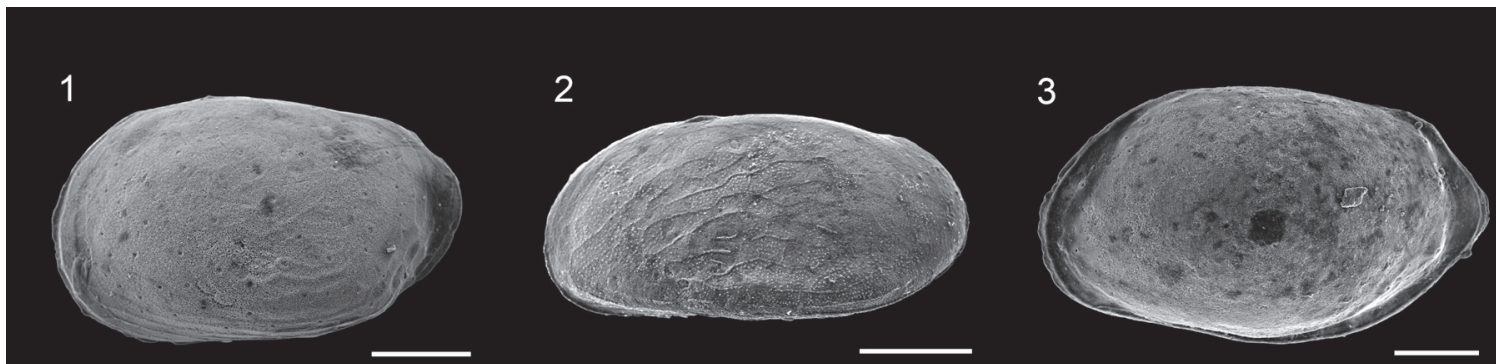

4

5

6
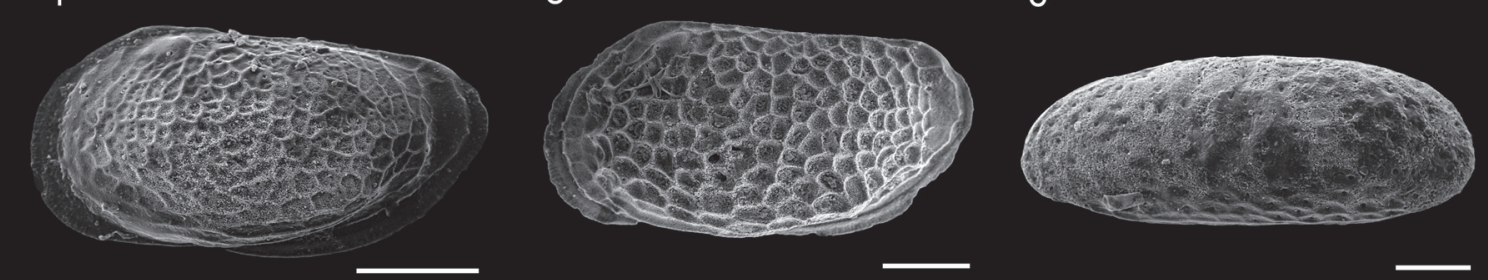

9

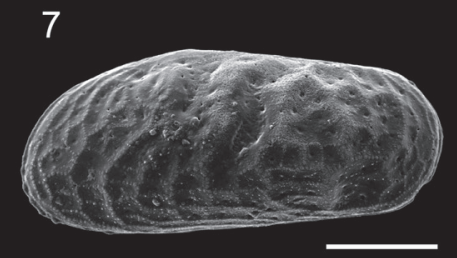

8

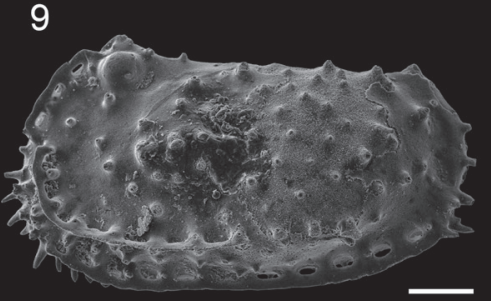

10

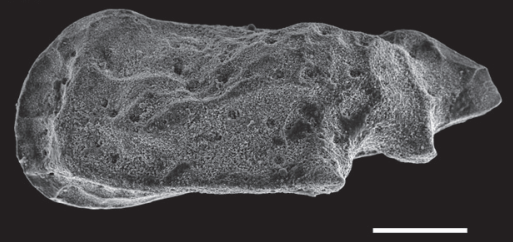

13

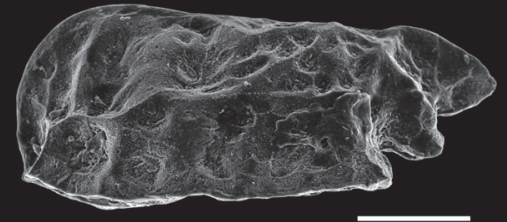

11

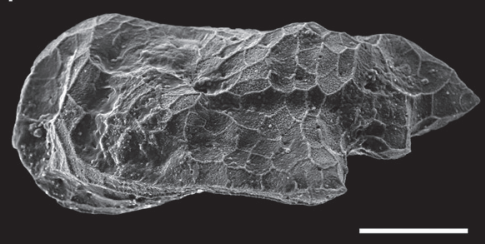

14

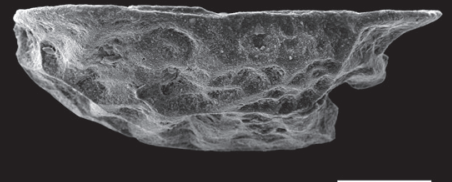

12

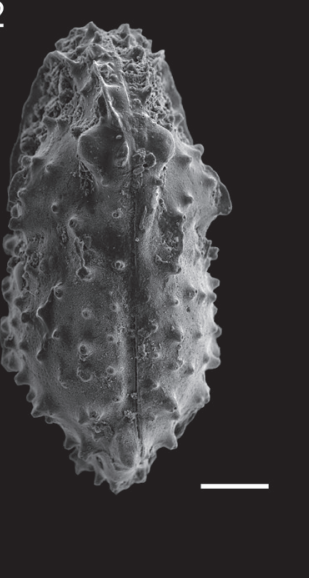

FIGURE 16. 1 "Elofsonia" minima (Bonaduce, Ciampo and Masoli, 1976), left valve, female, sample STZC 27, ABMC 2017/075; 2 "Elofsonia" minima (Bonaduce, Ciampo and Masoli, 1976), left valve, male, sample STZC 28, ABMC 2017/066; 3 Palmoconcha turbida (Müller, 1912), left valve, sample STZC 27, ABMC 2017/032; 4 Sagmatocythere versicolor (Müller, 1894), juv, left valve, sample STZC 28, ABMC 2017/081; 5 Sagmatocythere versicolor (Müller, 1894), left valve, sample STZC 33, ABMC 2017/085; 6 Procytherideis retifera Ruggieri, 1978, left valve, sample STZC 29, ABMC 2017/063; 7 Procytherideis subspiralis (Brady, Crosskey and Robinson, 1874), left valve, sample STZC 33, ABMC 2017/079; 8 Sahnicythere retroflexa (Klie, 1936), right valve, sample STZC 33, ABMC 2017/065; 9 Carinocythereis whitei (Baird, 1850), left valve, sample STZC 31, ABMC 2017/046; 10 Paracytheridea paulii Dubowsky, 1939, left valve, sample STZC 32, ABMC 2017/026; 11 Paracytheridea paulii Dubowsky, 1939, left valve, sample STZC 26, ABMC 2017/080; 12 Carinocythereis whitei (Baird, 1850), carapace in dorsal view, sample STZC 28, ABMC 2017/071; 13 Paracytheridea triquetra (Reuss, 1850), left valve, sample STZC 29, ABMC 2017/022; 14 Paracytheridea triquetra (Reuss, 1850), left valve in dorsal view, sample STZC 29, ABMC 2017/022; Scale bar 100 $\mu \mathrm{m}$. 
present in scattered samples of Section C with maximum RA of $5.54 \%(\mathrm{MNI})$.

Family NEOCYTHERIDEIDAE Puri, 1957

Genus PROCYTHERIDEIS Ruggieri, 1978

Procytherideis retifera Ruggieri, 1978

\section{Figure 16.6}

1978 Procytherideis retifera Ruggieri: p. 10.

1976a Neocytherideis sp. 1 Bonaduce, Ciampo and Masoli: p. 62, pl. 36, figs. 5-11.

1997 Procytherideis retifera Ruggieri; Barra, p. 78, pl. 2, fig. 3.

1988 Procytherideis retifera Ruggieri; Amore, Barra, Ciampo, Ruggiero Taddei, Russo and Sgarrella, p. 976.

1990 Procytherideis retifera Ruggieri; Amore, Barra, Ciampo, Ruggiero Taddei, Russo and Sgarrella, p. 484.

2008 Procytherideis retifera Ruggieri; Faranda and Gliozzi, pl. 2, figs. 1-2.

Distribution and remarks. Procytherideis retifera is an infralittoral species (Bonaduce et al., 1976a; Barra, 1997) uncommon in the studied assemblages, occurring in three samples of Section C with a maximum $\mathrm{RA}$ of $5.50 \%$ (MNI).

Procytherideis subspiralis (Brady, Crosskey and Robinson, 1874)

Figure 16.7

1874 Cytherideis subspiralis Brady, Crosskey and Robinson: p. 211, pl. 10, figs. 16-17.

1976a Neocytherideis subspiralis (Brady, Crosskey and Robinson); Bonaduce, Ciampo and Masoli, pp. 62-63, pl. 35, figs. 11-14.

$1988 \quad$ Neocytherideis subspiralis (Brady, Crosskey and Robinson); Amore, Barra, Ciampo, Ruggiero Taddei, Russo and Sgarrella, p. 976.

1990 Neocytherideis subspiralis (Brady, Crosskey and Robinson); Amore, Barra, Ciampo, Ruggiero Taddei, Russo and Sgarrella, p. 483.

2004 Procytherideis subspiralis (Brady, Crosskey and Robinson); Bonaduce and McKenzie, pp. 105, 107, text figs. 3A-H.

Distribution and remarks. Only few juvenile specimens of this upper circalittoral species (Bonaduce et al., 1976a) have been found in the sample STZC 33.

Genus SAHNICYTHERE Athersuch, 1982 Sahnicythere retroflexa (Klie, 1936)

Figure 16.8

1936 Cytherideis retroflexa Klie: p. 52 figs. 4-11.

1988 Sahnia subulata (Brady); Amore, Barra, Ciampo, Ruggiero Taddei, Russo and Sgarrella, p. 976.
1990

Sahnia subulata (Brady); Amore, Barra, Ciampo, Ruggiero Taddei, Russo and Sgarrella, p. 484.

1989 Sahnicythere retroflexa (Klie); Athersuch, Horne and Whittaker, p. 128, text-fig. 49; pl. 3, fig. 8.

Distribution and remarks. Sahnicythere retroflexa generally occurs in the infralittoral zone (Bonaduce et al., 1976a, as Sahnia subulata; Athersuch et al., 1989; Mangoni et al., 2016). It is rare at La Starza, some valves occurring only in the sample STZC 33.

Family PARACYTHERIDEIDAE Puri, 1957

Genus PARACYTHERIDEA Müller, 1894

Paracytheridea paulii Dubowsky, 1939

Figure 16.10-11

1939 Paracytheridea paulii Dubowski: p. 52, figs. 15-18.

1969 Paracytheridea paulii Dubowski; Schornikov, p. 202, pl. 29, fig. 1.

1971 Paracytheridea parallia var. A; Barbeito-Gonzalez, pl. 28, figs. $5 \mathrm{c}-6 \mathrm{c}$.

Distribution and remarks. The present is the first fossil record of this infralittoral (Barbeito-Gonzalez, 1971) species rarely recorded in the Mediterranean. Uncommon in the La Starza succession.

Paracytheridea triquetra (Reuss, 1850)

Figure 16.13-14

1850b Cypridina triquetra Reuss: p. 82, pl. 10, fig. 19.

2004 Paracytheridea triquetra (Reuss); Aiello and Szczechura, p. 39, pl. 8, fig. 16.

Distribution and remarks. Paracytheridea triquetra is a species characteristic of the European Neogene shallow waters (Aiello and Szczechura, 2004); it occurs in the sediments of Section C, relatively rare.

Family TRACHYLEBERIDIDAE Sylvester-Bradley, 1948

Genus ACANTHOCYTHEREIS Howe, 1963 Acantocythereis histryx (Reuss, 1850)

1850b Cypridina hystrix Reuss: p. 74, pl. 10, figs. 6ac.

1979a Acantocythereis histryx (Reuss); Athersuch, pp. 133-140.

Distribution and remarks. Acantocythereis hystrix is a shelf species mainly recorded in the circalittoral zone of the Adriatic Sea (Bonaduce et al., 1976a; Breman, 1976) and in the upper infralittoralparalic of the eastern Mediterranean (Kubanç, 2005). The specimens recorded in some samples of Sections B and C are poorly preserved. 
Genus CARINOCYTHEREIS Ruggieri, 1956

Carinocythereis whitei (Baird, 1850)

Figure 16.9, 16.12

1850 Cythereis Whitei sp. nov. Baird: p. 175, pl. 20, figs. 3-3a.

1964 Carinocythereis quadridentata (Baird); Rodriquez, p. 113, pl. 6, fig. I.4.

1987 Carinocythereis whitei (Baird); Athersuch and Whittaker, pp. 103-110.

1988 Carinocythereis antiquata (Baird); Amore, Barra, Ciampo, Ruggiero Taddei, Russo and Sgarrella, p. 976.

1989 Carinocythereis whitei (Baird); Athersuch, Horne and Whittaker, p. 137, fig. 54; pl. 4, fig. 2.

1990 Carinocythereis antiquata (Baird); Amore, Barra, Ciampo, Ruggiero Taddei, Russo and Sgarrella, pp. 483, 485.

Distribution and remarks. Carinocythereis whitei has been recorded in the infralittoral - upper circalittoral zone, mostly in the depth range 0-60 m on silty-sandy bottom sediments (Athersuch et al., 1989; Aiello et al., 2006). Common at La Starza in Section C, reaching a RA peak of $34.07 \%$ (MNI).

Genus CISTACYTHEREIS Uliczny, 1969 Cistacythereis (Hiltermannicythere) turbida (Müller, 1894)

Figure 17.5-6

1894 Cythereis turbida Müller: p. 371, pl. 28, figs. 22, 27; pl. 31, fig. 7.

1976a Hiltermannicythere turbida (Müller); Bonaduce, Ciampo and Masoli, pp. 49-50, pl. 24, figs. 7-9.

1988 Hiltermannicythere turbida (Müller); Amore, Barra, Ciampo, Ruggiero Taddei, Russo and Sgarrella, p. 976.

1990 Hiltermannicythere turbida (Müller); Amore, Barra, Ciampo, Ruggiero Taddei, Russo and Sgarrella, pp. 483, 485.

2006 Cistacythereis (Hiltermannicythere) turbida (Müller); Aiello, Barra, Coppa, Valente and Zeni, tab. 3.

Distribution and remarks. A shelf species recorded from the upper infralittoral (Aiello et al., 2006) to the lower circalittoral, with an optimum in the depth range 27-125 mbsl (Bonaduce et al., 1977). It is present in the majority of the samples of Section C, with maximum RA of $19.32 \%$ (MNI).

Genus COSTA Neviani, 1928

Costa edwardsii (Roemer, 1838)

Figure 17.1-4

1838b Cytherina edwardsii Roemer: p. 518, pl. 6, fig. 27.
1988 Costa edwardsii (Roemer); Amore, Barra, Ciampo, Ruggiero Taddei, Russo and Sgarrella, p. 976.

1990 Costa edwardsii (Roemer); Amore, Barra, Ciampo, Ruggiero Taddei, Russo and Sgarrella, pp. 483, 485, pl. 5, fig. 5.

2006 Costa edwardsii (Roemer); Mostafawi and Matzke-Karasz, pp. 16, 18, pl. 1, figs. 6-7.

2008 Costa edwardsii (Roemer); Faranda and Gliozzi, pp. 234-235, pl. 6, figs. 1, 4, 7, 10.

Distribution and remarks. This species, also reported as C. runcinata (Baird, 1850), lives in lower infralittoral to lower circalittoral waters, being very rare above $20 \mathrm{mbsl}$. It shows its optimum in the upper circalittoral zone $(\sim 40-100 \mathrm{mbsl})$ (Bonaduce et al., 1976a; Breman, 1976; Lachenal, 1989; Mostafawi and Matzke-Karasz, 2006).

Costa edwardsii is one of the characteristic species of the ostracod assemblages of the La Starza succession, ranging in the Section $\mathrm{C}$ from $4.60 \%$ to $58.25 \%$ (MNI) and from $9.64 \%$ to $53.61 \%$ (TNV); it shows its maximum RA value in Section B, with $78.63 \%$ (TNV). The distribution of $C$. edwardsii in Section $C$ suggests its tolerance to phases of stressed physico-chemical bottom water conditions.

Genus PTERYGOCYTHEREIS Blake, 1933

Pterygocythereis coronata (Roemer, 1838)

1838b Cytherina coronata Roemer: p. 518, pl. 6, fig. 30.

1988 Pterygocythereis siveteri Athersuch; Amore, Barra, Ciampo, Ruggiero Taddei, Russo and Sgarrella, p. 976.

1990 Pterygocythereis siveteri Athersuch; Amore, Barra, Ciampo, Ruggiero Taddei, Russo and Sgarrella, p. 484.

2008 Pterygocythereis coronata (Roemer); Faranda and Gliozzi, p. 238, pl. 7, fig. 1.

Distribution and remarks. A lower infralittoral and upper circalittoral species frequently recorded as $P$. ceratoptera (Bosquet, 1852) and P. siveteri Athersuch, 1978a (Bonaduce et al., 1976a, 1977; Faranda and Gliozzi, 2008). Relatively common in the La Starza assemblages, with a maximum RA of $26.05 \%$ (TNV).

Pterygocythereis jonesii (Baird, 1850) Figure 17.7-8

1850 Cythereis Jonesii Baird: p. 175, pl. 20, fig. 1.

1964 Pterygocythereis jonesii (Baird); Rodriquez, p. 113, pl. 6, fig. I.7.

1978b Pterygocythereis jonesii (Baird); Athersuch, pp. 9-16. 


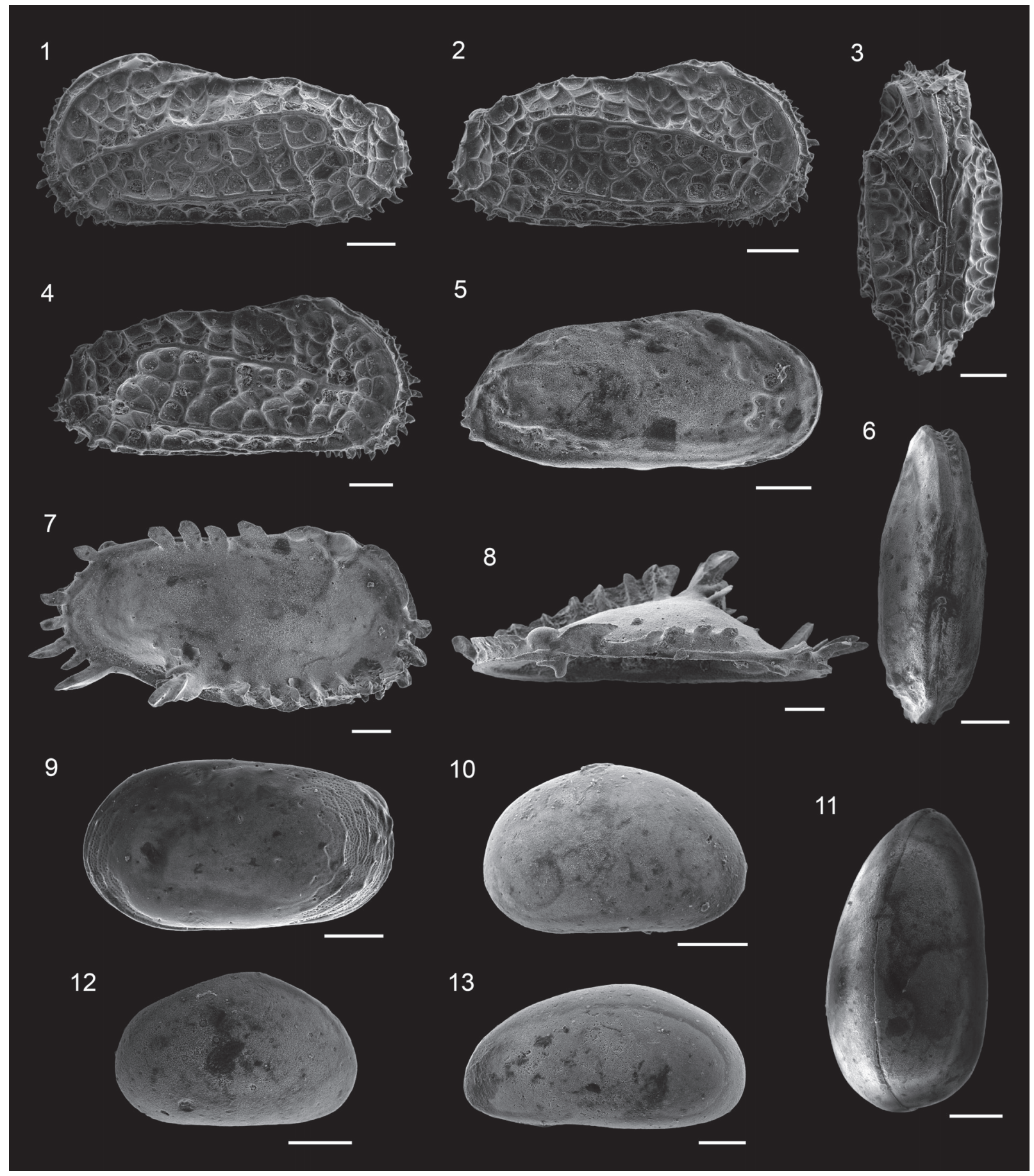

FIGURE 17. 1 Costa edwardsii (Roemer, 1838), left valve, sample STZC 19, ABMC 2017/042; 2 Costa edwardsii (Roemer, 1838), right valve, sample STZC 22, ABMC 2017/052; 3 Costa edwardsii (Roemer, 1838), carapace in dorsal view, sample STZC 19, ABMC 2017/073; 4 Costa edwardsii (Roemer, 1838), right valve, sample STZC 28, ABMC 2017/090; 5 Cistacythereis (Hiltermannicythere) turbida (Müller, 1894), right valve, sample STZC 25, ABMC 2017/021; 6 Cistacythereis (Hiltermannicythere) turbida (Müller, 1894), carapace in dorsal view, sample STZC 26, ABMC 2017/ 027; 7 Pterygocythereis jonesii (Baird, 1850), right valve, sample STZC 34, ABMC 2017/023; 8 Pterygocythereis jonesii (Baird, 1850), right valve in dorsal view, sample STZC 34, ABMC 2017/028; 9 Rectobuntonia subulata (Ruggieri, 1954), left valve, sample STZC 33, ABMC 2017/029; 10 Xestoleberis communis Müller, 1894, right valve, sample STZC 27, ABMC 2017/064; 11 Xestoleberis dispar Müller, 1894, carapace in dorsal view, sample STZC 22, ABMC 2017/040; 12 Xestoleberis ? rara Müller, 1894, right valve, sample STZC 27, ABMC 2017/087; 13 Xestoleberis dispar Müller, 1894, left valve, sample STZC 21, ABMC 2017/037; Scale bar 100 m. 
1988 Pterygocythereis jonesii (Baird); Amore, Barra, Ciampo, Ruggiero Taddei, Russo and Sgarrella, p. 976.

1990 Pterygocythereis jonesii (Baird); Amore, Barra, Ciampo, Ruggiero Taddei, Russo and Sgarrella, p. 484.

2004 Pterygocythereis jonesii (Baird); Aiello and Szczechura, pp. 27-28, pl. 5, fig. 8.

Distribution and remarks. Pterygocythereis jonesii is a shelf species (extensive literature in Aiello and Szczechura, 2004), not rare at La Starza in Sections B and C. In the sample STZC 16 the ostracod assemblage consists of two valves of $P$. jonesii. RA (except sample STZC 16) ranges from 0.85 to $10.80 \%$ (MNI) and from 0.41 to $22.60 \%$ (TNV).

Genus RECTOBUNTONIA Sissingh, 1972

Rectobuntonia subulata (Ruggieri, 1954)

Figure 17.9

1954 Buntonia subulata Ruggieri: p. 568, figs. 3437.

1976b Buntonia subulata Ruggieri; Bonaduce, Pugliese and Minichelli, pp. 429-432, figs. 1a-1g, figs. 2.1-2.3.

1988 Rectobuntonia subulata (Ruggieri); Amore, Barra, Ciampo, Ruggiero Taddei, Russo and Sgarrella, p. 976.

1990 Rectobuntonia subulata (Ruggieri); Amore, Barra, Ciampo, Ruggiero Taddei, Russo and Sgarrella, pp. 484-485, pl. 4, fig. 2.

2004 Rectobuntonia subulata (Ruggieri); Bonaduce and McKenzie, pp. 103, 105; text-figs. $2 \mathrm{H}-\mathrm{R}$.

Distribution and remarks. This species, uncommon in lower infralittoral and lower circalittoral waters, shows its optimum in the upper circalittoral zone (Schornikov, 1969; Bonaduce et al., 1976b, 1977, 1988; Yassini, 1979). At La Starza has been recorded in ten samples of Section $C$ from the sample STZC 17 to STZC 34, with low RA values.

Family XESTOLEBERIDIDAE Sars, 1928 Genus XESTOLEBERIS Sars, 1866 Xestoleberis communis Müller, 1894

Figure 17.10

1894 Xestoleberis communis Müller: p. 338, pl. 25, figs. 32-33, 39, pl. 10, figs. 78-83.

1978c Xestoleberis communis Müller; Athersuch, p. 296, pl. 9, figs. 1-4; pl. 10, figs. 1, 3-5; pl. 17, fig. 8; text-figs. 5b, d, 8c, 10b-c.

1988 Xestoleberis communis Müller; Amore, Barra, Ciampo, Ruggiero Taddei, Russo and Sgarrella, p. 977.

1990 Xestoleberis communis Müller; Amore, Barra, Ciampo, Ruggiero Taddei, Russo and Sgarrella, p. 484.
1997 Xestoleberis communis Müller; Barra, p. 87, pl. 6 , fig. 1.

Distribution and remarks. Xestoleberis communis is widely distributed in the infralittoral and upper circalittoral Mediterranean waters (Frezza and Di Bella, 2015). The shells recovered in Section C deposits pertain mainly to young instars; RA values generally low.

\section{Xestoleberis dispar Müller, 1894}

Figure 17.11, 17.13

1894 Xestoleberis dispar Müller: p. 334, pl. 25, figs. 2-3, 9, 35.

1976 Xestoleberis dispar Müller; Bonaduce, Ciampo and Masoli, p. 124, pl. 73, figs. 1-3.

1988 Xestoleberis dispar Müller; Amore, Barra, Ciampo, Ruggiero Taddei, Russo and Sgarrella, p. 977

1990 Xestoleberis dispar Müller; Amore, Barra, Ciampo, Ruggiero Taddei, Russo and Sgarrella, pp. 484-485.

1997 Xestoleberis dispar Müller; Barra, p. 87, pl. 7, figs. 7-8.

Distribution and remarks. An infralittoral and, subordinately, upper circalittoral species (Bonaduce et al., 1976a, 1977, 1988) not rare in the main part of the fossiliferous samples at La Starza, with a maximum RA of $14.81 \%$.

\section{DISCUSSION}

In an environmental context under the influence of volcanic activities both paleodepth trends and the physico-chemical characteristics of paleobottom waters can show remarkable variations over a relatively brief time span and in limited areas, as shown, for example, by the events linked to the 1538 CE eruption at Monte Nuovo (Di Vito et al., 2016). Previously, Amore et al. (1988, 1990) investigated the paleoenvironmental characteristics of the sediments of two sections (Proprietà Sersale and Proprietà Fusco) on the basis of the foraminiferal, ostracod and macrobenthic assemblages. Amore et al. (1988) divided the succession into three intervals: the lower part possibly deposited in the depth range $10-20 \mathrm{~m}$, the middle one with a paleodepth of 15-20 m, and the upper interval showing a transgressive trend from lower infralittoral $(20-30 \mathrm{~m})$ to upper circalittoral zone (40-50 m). In Amore et al. (1990) one foraminifer and one ostracod new species were described and paleoenvironmental features, with special regards to bottom water conditions, are discussed, confirming the paleobathymetric evaluations of Amore et al. (1988) and suggesting a depositional environ- 
ment characterized by low $\mathrm{pH}$ waters. Ciampo (2004) tested on the same material a method of paleobathymetric reconstruction based on the comparison between the percentage species composition of fossil ostracod assemblages and polynomial patterns of depth distribution data of the species in the Mediterranean. The author analyzed four samples of the Fusco Section and one sample of the Sersale Section, with an inferred paleobathymetry ranging from 10.5 to $47.8 \mathrm{~m}$.

Data presented herein show that the discontinuous volcanic activity in the Campi Flegrei caldera and the related ground deformations in the area of La Starza were characterized by multiple subsidence and uplift events, conditioning the composition of the Holocene meiofaunal assemblages. Benthic foraminiferal and ostracod assemblages exhibit very different compositions in approximately coeval intervals of the study sections because of different physico-chemical conditions in a small area. This is most likely due to the presence of a paleo-hydrothermal system comparable to the shallow ventings reported in the Tyrrhenian Sea and characterized by formation of acidic waters (Dando et al., 1999; Hall-Spencer et al., 2008; Boatta et al., 2013; Ingrassia et al., 2015a; b).

In the La Starza succession the state of preservation of fossil remains is moderately good in some samples and poor in others. As previously stated a number of assemblages consist exclusively of siliceous remains, and miliolids are very rare. These data suggest the presence of waters undersaturated in $\mathrm{CaCO}_{3}$ at different degrees during the deposition of the succession. Marine waters in volcanic environments may be strongly influenced by deposition of volcanic ashes, erosion of volcanic soils and especially volcanic vents or cold seeps activity (Frogner et al., 2001; Kiel, 2010; Wall-Palmer et al., 2011). These factors may alter the physico-chemical parameters of the bottom sediments and waters due to the release of free gas, (mainly carbon dioxide, nitrogen, methane, sulphur dioxide, hydrogen sulphide, hydrogen), to increased temperature, high concentration of heavy metals and decreased $\mathrm{pH}$, resulting toxic to organisms (Dando, 2010; v. therein for extensive references). Shallow marine hydrothermal vent systems are frequently characterized by biota, such as nematodes and polychaetes, devoid of easily fossilizable parts, able to live in extreme ecological conditions where macrofauna is not present (Kamenev et al., 1993; Hoaki et al., 1995). As a general rule in the vicinity of the vent outlets the diversity decreases, the dominance of tolerant spe- cies increases (Melwani and Kim, 2008; Zeppilli and Danovaro, 2009; Karlen et al., 2010; Chan et al., 2016) and the bottom waters are frequently corrosive to calcium carbonate inhibiting the calcification of shelled organisms (Cigliano et al., 2010; Ricevuto et al., 2012; Boatta et al., 2013).

Previous investigations on benthic foraminifers in Tyrrhenian vent systems provide information allowing a comparison between living-subrecent and fossil assemblages; on the other hand, ostracod data are very limited. The species able to tolerate the higher hydrothermal stress, including low $\mathrm{pH}$ bottom waters, mainly pertain to agglutinated taxa (Panieri, 2006; Dias et al., 2010; Di Bella et al., 2016) that are not recorded in the La Starza succession. All studied sections display both barren marine sediments and deposits devoid of calcareous fossils, possibly testifying persisting acidic conditions or toxic phases including $\mathrm{CO}_{2}$ emissions, with $\mathrm{pH}$ values lower than 7.6-7.9 (Dias et al., 2010; Uthicke et al., 2013; Pettit, 2015). The presence of siliceous microfossils suggests some resemblances with environments dominated by siliceous sponges described by Tarasov et al. (1999). As previously recorded in the Pleistocene of the Procida Island (Aiello et al., 2007; Aiello et al., 2012) and in the Recent (Di Bella et al., 2016) the calcareous assemblages of La Starza include very rare specimens of miliolids, suggesting deposition in waters with $\mathrm{pH}$ values lower than 8.14 (Dias et al., 2010).

Shallow marine hydrothermal environments characterised by dominant $P$. oceanica, have been described from the Ischia Island, where hydrogen sulphide is not present (Hall-Spencer et al., 2008). This species is a seagrass which tolerates moderate levels of hydrothermal emissions (Aliani et al., 1998; Dando, 2010), is sensitive to intense degassing episodes (Panieri, 2006) and especially to sulphide emissions (Garcias-Bonet et al., 2008). HallSpencer et al. (2008) described an environmental context showing remarkable affinities with the features recorded at La Starza in the substage g1, where rhizomes of $P$. oceanica occur in six sections alternating with both fossiliferous and barren layers.

Panieri et al. (2005) reported an unusual occurrence of $P$. oceanica meadows at a water depth of about $80 \mathrm{~m}$ in Secca dei Pesci, a site characterized by low-temperature emissions. Foraminiferal assemblages are dominated by Cibicides lobatulus, Asterigerinata mamilla, Reussella spinulosa, Globocassidulina subglobosa and Elphidium complanatum. These species are well represented 
in the La Starza sediments, where generally the dominant genera are Ammonia and Elphidium, a difference due, in our opinion, to different deposition depth.

The analysis of the microfossil remains and the comparison with the stratigraphic and sedimentary features of the succession allowed the discrimination of eight stages (a-h) and the reconstruction of paleoenvironmental trends (Figure 7).

The level of detail of the paleoecological reconstruction depends on the foraminiferal and ostracod assemblages. The presence and state of preservation of calcareous microfossils in a volcanic environment are linked to physico-chemical conditions of the bottom waters. If they are strongly undersaturated in $\mathrm{CaCO}_{3}$ only siliceous remains can be preserved. In some levels of the succession of La Starza well-preserved benthic foraminiferal and ostracod assemblages allowed to reconstruct variations in paleobathymetry ranging from upper infralittoral to upper circalittoral zone.

\section{Stages}

Stage a. The lowermost interval is part of the Epoch I of volcanic activity of Campi Flegrei (1510.6 k.y.a) and comprises the oldest of the studied sediments, recovered in the Tunnel Section, including only the sample Tun 1 . The sedimentological features of the beds of fine-medium sands and coarser sediments suggest a deposition in the wetted-subaerial part of a washover fan, in the supralittoral zone.

Stage $\mathbf{b}$. This stage is represented by sediments deposited during the upper part of the Epoch I that includes two levels that provide mean ages of 11.23 and 10.46 k.y.a, respectively (Figure 2). Samples pertaining to this interval are: Tun 2-15; STZD 1-2; STZC 1-5; STZE 1. Within Stage b barren sediments prevail. Sandy beds with cross-laminated and wedge-shaped bed-set packages sedimentary structures suggest a mediolittoral upper infralittoral zone, characterized by bar and trough systems, below the low tide level or in rip channels due to longshore currents or waves action, in low $\mathrm{pH}$ waters. The uppermost level (sample STZE 1) yielded assemblages showing moderately stressed bottom waters, in lower infralittoral paleoenvironment, with unfavourable conditions for ostracods. The high RA of the species C. edwardsii (>38\%) is possibly due to its tolerance to environmental stress.

Stage c. The alternations of fine to coarse sediments of Stage $c$, deposited during the quiescence period (10.6-9.6 k.y.a) following Epoch I, and during the beginning of the Epoch II, include the samples Tun 16-19, STZB 1 and STZC 6-12. They are mainly devoid of microfossils, except STZC 7 and STZC 9. Fossil content, consisting of siliceous remains and, in the sample STZC 7, of a single test of $E$. granosum, and sedimentological characteristics suggest a marginal to upper infralittoral marine paleoenvironment, undersaturated in $\mathrm{CaCO}_{3}$, under unfavourable physico-chemical conditions.

Stage d. This stage corresponds with the upper part of Epoch II. Samples Tun 20-22, STZB 2-3 and STZC 13-16 have been collected within this interval. Assemblages are largely dominated by siliceous microfossils, except the sample STZC 13, which contains benthic foraminifers, and the samples STZC 15-16 where both ostracod and foraminiferal remains occur. The inferred paleoenvironment ranges from mediolittoral to upper infralittoral zone, in marine very low to moderately low $\mathrm{pH}$ waters. The CFRA values vary from $22.02 \%$ (STZC 15) to 0\% (STZC 16) suggesting a regressive trend, culminating in the emersion episode of the following stage.

Stage e. It corresponds to an emersion phase occurred at $\sim 9.1$ k.y.a, testified by an orange brown pedogenised level (no samples collected in this layer).

The following two intervals (stage $f$ and substage g1) represent the rest phase between Epoch II and Epoch III, in the time range $\sim 9.1$ to $\sim 5.5$ k.y.a.

Stage $f$. In this interval the following samples have been collected: STZB 4-9, STZC 17-26, STZE 2-4, STZF 1. A level belonging to the lower part of this stage (Figure 2 ) provided a mean age of $\sim 8.6$ k.y.a. Assemblages testify the beginning of a trangressive phase at about 8.5 k.y.a. The assemblages of Stage $f$ show different compositions and state of preservation in various sections. In the section $B$ the samples STZB 4, STZB 7-9 yielded assemblages consisting mainly of siliceous microfossils suggesting a marine paleoenvironment with low $\mathrm{pH}$ waters. In the samples STZB 5-6 benthic foraminiferal and ostracods assemblages confirm the transgressive trend from infralittoral to upper circalittoral zone. CFRA reaches $20.7 \%$ in the sample STZB 5 and $30.89 \%$ in the sample STZB 6, whereas CORA is $15.38 \%$ (MNI) and $16.81 \%$ (TNV) in STZB 5 and $80.49 \%$ (MNI) and $88.89 \%$ (TNV) in STZB 6.

In the lowermost sample of this stage in the Section C (STZC 17), circalittoral foraminifers are not present $(C F R A=0)$, indicating an upper infralittoral paleonvironment. In the following samples 
(STZC 18-19) a rapid increase of paleodepth is documented, with deposition in upper circalittoral waters with high values of CFRA and CORA [STZC 18: $\quad$ CFRA $=25.69 \%$; $C O R A=89.32 \% \quad(\mathrm{MNI})$ and $86.67 \%$ (TNV). STZC 19: CFRA $=25.66 \%$, CORA $=55.40 \%$ (MNI) and $68.07 \%$ (TNV)]. High values of TFRA (STZC 18 $=60.93 \%$; STZC $19=46.90 \%$ ) and AE (STZC 18=31.61; STZC $19=35.90$ ) indicate possibly low oxygen bottom waters.

Assemblages of the samples STZC 20-26, making up the subcluster B2, suggest a persisting upper circalittoral (CFRA ranges from $21.67 \%$ to $36.94 \%$, CORA (MNI) from $15.94 \%$ to $28.99 \%$, CORA (TNV) from $15.66 \%$ to $51.87 \%$ ), moderately stressed, paleoenvironment.

The benthic foraminiferal assemblage of the sample STZE 2 shows a medium-low CFRA $(16.48 \%)$, probably representing an intermediate paleodepth, in lower infralittoral zone, between the samples STZC 17 and STZC 18 during the early Stage $f$ trangression. The lack of foraminiferal and ostracod remains of the samples STZE 3-5 suggests the variability of sedimentary and/or postsedimentary physico-chemical conditions in the complex depositional system of the Campi Flegrei caldera.

The benthic foraminiferal assemblage of the sample STZF 1, belonging to the upper part of Stage $\mathrm{f}$, suggests a deposition in lower infralittoral upper circalittoral zone (CFRA $=19.8 \%$ ), in environmental conditions unfavourable for ostracod life.

Stage g. The stage has been split in two substages. The first one, substage $\mathrm{g} 1$, starts slightly before the level dated to $\sim 5.86$ k.y.a and includes the upper part of the quiescent period between Epoch II and Epoch III. The boundary between substages g1 and g2, separated by an erosional surface, corresponds to the beginning of Epoch III at $\sim 5.5$ k.y.a. Stage g ends with the Cigliano volcanic deposits (mean age $=5.247$ k.y.a). Substage g1 includes the samples: Tun 23-30, STZA 1-6, STZB 10, STZC 27-35, STZE 5-9 and STZF 2-4. In the Tunnel Section and in the sections A, B, C, E and F the substage $\mathrm{g} 1$ is marked by levels with rhizomes of $P$. oceanica, a seagrass species characteristic of the infralittoral zone of the Mediterranean, presently reaching a maximum depth of $\sim 50 \mathrm{mbsl}$ (Boudouresque et al., 2006). The deposits of the Tunnel Section, STZA, STZB and STZE suggest a stressed marine paleoenvironment where calcareous remains are very rare or lacking. The assemblages of the Section $C$ show that this substage is characterized by moderate paleobathymetric fluc- tuations, ranging from lower infralittoral to the uppermost part of the circalittoral zone (STZC 2734: CORA (MNI) $=$ from $8.14 \%$ to $45.34 \%$; CORA (TNV): from $13.51 \%$ to $50.68 \%$; CFRA: from $16.41 \%$ to $25.5 \%$ ). The samples STZF $2-4$ are deposited in a deepening phase where CFRA $=0 \%$ in the lower sample (STZF 2) and increase in STFZ 3 (CFRA $=7.69 \%)$ and STZF 4 (CFRA $=20.27 \%)$; in this last sample ostracods are present and the circalittoral species $C$. edwardsii is well represented. The uppermost sample of Section C (STZC 35), belonging to the substage g1, yielded only siliceous remains, suggesting a new episode of marine waters undersaturated in $\mathrm{CaCO}_{3}$.

In the second substage (g2) only the sample Tun 35 is fossiliferous, showing a marine paleoenvironment in low $\mathrm{pH}$ waters (paleodepth not detectable).

Stage $\mathbf{h}$. All the sediments belonging to this interval are barren, and the paleoenvironmental variations showed in Figure 7 are based on the sedimentary features of the sandy layers of the Pozzuoli unit sampled in the Tunnel Section (Tun 36-38) and in the Section A (STZC 12). A marine paleoenvironment (paleodepth not detectable) is supported by the record of rare and poorly preserved echinoid and bryozoans remains in similar deposits collected in the same area (Isaia, Aiello and Barra, pers. obs.).

\section{CONCLUSIONS}

The La Starza outcrops represent a sedimentary complex deposited in a late Quaternary caldera during a time span of about $8 \mathrm{ka}$. The interplay between sea level variations and subsidence-uplift episodes linked to volcanic activities originated alternating marine trangressions and regressions, as shown by the composition of meiofaunal assemblages. They consist of infralittoral and upper circalittoral taxa commonly recorded in the recent Mediterranean waters, exhibiting a number of peculiarities. Actually, benthic foraminiferal and ostracod assemblages are characterized by the lack, or very low relative abundance, of taxa sensitive to stressed environmental conditions and by high mean relative abundances of some stresstolerant species.

The comparison of the calcareous remains of La Starza terrace and the thanatocoenosis of the infralittoral and upper circalittoral bottom sediments of the nearby coastal areas of Monte di Procida (Mangoni et al., 2016) and of the Gulf of Pozzuoli (Aiello, Barra and Parisi, pers. obs.) highlights some differences between Holocene and Recent- 
subrecent assemblages. The fossil benthic foraminifers display higher relative abundances of Haynesina spp. and Nonionella turgida, well-known stress-tolerant taxa; Elphidium spp. show very high percentage values; conversely, miliolids, which are dominant in Recent assemblages, are almost completely lacking. In the ostracod assemblages of La Starza we have observed an unusual abundance of trachyleberidid genera and the absence, or scanty occurrence, of some species such as Aurila convexa, Neocytherideis muelleri, and Sahnicythere retroflexa generally well-represented in the infralittoral and upper circalittoral zone of this area.

A paleoenvironmental model under the persisting influence of volcanic vents with rapid variations of hydrothermal emissions, varying in limited areas, seems to fit adequately with the paleontological and sedimentary characters of the La Starza succession, exhibiting notable similarities with Recent vent systems described from the Tyrrhenian Sea.

Generally, abundance and diversity of taxa with calcareous hard-parts decrease in the proximity of hydrothermal vent, where $\mathrm{pH}$ and calcium carbonate saturation may be low and $\mathrm{pCO}_{2}$ high (Martin et al., 2008; Cigliano et al., 2010; Dias et al., 2010; Pettit, 2015).

The very rare findings of miliolids at la Starza fit well with the observations of Dias et al. (2010) on the assemblages occurring in the infralittoral waters of Ischia, showing that in normal conditions $(\mathrm{pH} 8.2-8.14)$ the porcelaneous foraminifers are abundant, whereas they are not recorded in waters with medium and low $\mathrm{pH}(7.8-7.6)$ near the $\mathrm{CO}_{2}$ seeps. They are rare in the Zannone Giant Pockmark (Di Bella et al., 2016) and very rare in Panarea waters (Panieri, 2006). The sensitivity of miliolids to acidic environment has been attributed to their high-Mg calcite test; on the other hand the remarkable high relative abundances of the genus Elphidium in the La Starza assemblages can be related with their tolerance to low calcite saturation waters, associated with a low-Mg calcite shell (Bentov and Erez, 2006; Pettit, 2015). Assemblages showing high simple diversity and abundance of Elphidium spp. have been recorded on Padina pavonica thalli in the Vulcano waters by Pettit (2015).

The relatively low percentages of phytophilous taxa found in the La Starza show some resemblances with the oligotrophic environment pointed out by Pettit et al. (2013). The authors suggest that the low density of bacteria on the seagrasses at Ischia can be an additional stress factor in middle- low $\mathrm{pH}$ waters for calcareous epiphytic foraminifers, due to the limited food supply.

In spite of the acknowledged importance of arenaceous foraminifers in low $\mathrm{pH}$ Recent environments, where they tend to replace the calcareous taxa (Dias et al., 2010; Pettit, 2015), in the La Starza succession agglutinated specimens are not present. Their absence in biocoenosis as well as in dead assemblages has been explained in different ways, being attributed to the presence of high_concentrations of heavy metals (Stubbies et al., 1996), seep gases such as methane or hydrogen sulfide (Panieri et al., 2014), oil and tar (Dermitzakis and Alafousou, 1987).

The little fossilization potential of arenaceous tests (Fillon and Hunt, 1974; Smith, 1987) can be due to direct oxidization and microbial degradation of organic cements, consequently the loss of the shell is frequent in presence of bioturbation or high temperatures (Goldstein and Barker, 1988; Loeblich and Tappan, 1989; Berkeley et al., 2007). Alternatively, absence of arenaceous specimens has been interpreted as the effect of physical disturbance (Mojtahid et al., 2016; Gandhi et al., 2017), absence of clay minerals and dominance by freshly broken non-clay minerals (Quilty, 2010), influence of warm bottom waters (Lowery et al., 2016). In some cases authors merely stated that no satisfactory explanation can be given (Debenay et al., 2001a). We suggest that the lack of agglutinated foraminifers in the La Starza assemblages may be due to relatively high water temperatures, similar to that presently recorded in the Phlegrean Fields area (Rodolfo-Metalpa et al., 2011), contributing to the destruction of the tests.

Occurrence of deposits yielding only siliceous remains has been interpreted as due to low $\mathrm{pH}$, high $\mathrm{pCO}_{2}$, low ?Calc paleoenvironment, in the vicinity of volcanic hydrothermal emissions. Panieri (2006) reported bottom sediments devoid of foraminiferal tests as the result of an exceptional vent activity in the infralittoral marine zone of Panarea. Pettit (2015) has hypothesized that foraminifers are not present in the Vulcano bottom samples, because of winnowing, the coarse grain size and the "inhospitable nature of the sediments", consisting of shards of glassy particles derived from volcanic events.

Completely barren samples are present in some parts of the succession. Except few continental levels, marine layers devoid of fossil remains seem indicative of a high level of environmental stress. Absence of spicules, the most abundant siliceous remains at La Starza, can be due to 
high sensitivity of sponges to high temperature, wide temperature fluctuations (Ellison and Farnsworth, 1992; Pawlik et al., 2007) and to bacteria low density (Krautter, 1998). Both these conditions have been recorded in the Ischia waters (Pettit et al., 2013; Pettit, 2015).

In sum, the varying depositional conditions characterizing the La Starza succession may be compared with some Recent environments under the influence of hydrothermal emissions occurring in the Tyrrhenian Sea, showing a remarkable affinity with the shallow waters of the island of Ischia.

\section{ACKNOWLEDGEMENTS}

The authors thank F. Frontalini (University of Urbino) and M. Hyžný (Comenius University in Bratislava, Slovakia), whose careful comments and suggestions greatly improved the manuscript, and R. de' Gennaro (DiSTAR, Università di Napoli Federico II) who took the SEM micrographs.

\section{REFERENCES}

Accordi, B. 1951. I foraminiferi tirreniani della Barma Grande. Annali dell'Università di Ferrara, 8:110-136.

Aiello, G. and Barra, D. 2010. Crustacea, Ostracoda. Biologia Marina Mediterranea, 17(Supplement 1):401-419. https://doi.org/10.1093/oso/9780199233267.003.0025

Aiello, G., Barra, D., Coppa, M.G., Valente, A., and Zeni, F. 2006. Recent infralittoral Foraminiferida and Ostracoda from the Porto Cesareo Lagoon (Ionian Sea, Mediterranean). Bollettino della Società Paleontologica Italiana, 45:1-14.

Aiello, G., Barra, D., De Pippo, T., and Donadio, C. 2012. Pleistocene Foraminiferida and Ostracoda from the Island of Procida (Bay of Naples, Italy). Bollettino della Società Paleontologica Italiana, 51:49-62.

Aiello, G., Barra, D., De Pippo, T., Donadio, C., and Petrosino, C. 2007. Geomorphological evolution of Phlegrean volcanic islands near Naples, southern Italy. Zeitschrift für Geomorphologie. N.F., 51:165-190. https://doi.org/10.1127/0372-8854/2007/0051-0165

Aiello, G., Barra, D., and Parisi, R. 2016. Intra- and interspecific shell variability of the genus Urocythereis Ruggieri, 1950 (Ostracoda: Hemicytheridae) in the La Strea Bay (Ionian Sea, Italy). European Journal of Taxonomy, 193:1-35. https://doi.org/10.5852/ejt.2016.193

Aiello, G. and Szczechura, J. 2004. Middle Miocene ostracods of the Fore-Carpathian Depression (Central Paratethys, southwestern Poland). Bollettino della Società Paleontologica Italiana, 43:11-70.

Aliani, S., Bianchi, C.N., Cocito, S., Dando, P.R., Meloni, R., Morri, C., NieMeyer, A., Peirano, A., and Ziebis, W. 1998. A map of seagrass meadows in Palaeochori Bay (Milos Island, Greece), a marine area with hydrothermal activity. Rapports et Proces-Verbaux des Réunions de la Commission Internationale pour l'Exploration Scientifique de la Mer Méditerranée, 35:512513.

Altenbach, A.V., Lutze, G.F., Schiebel, R., and Schönfeld, J. 2003. Impact of interrelated and interdependent ecological controls on benthic Foraminifera: an example from the Gulf of Guinea. Palaeogeography, Palaeoclimatology, Palaeoecology, 197:213-238. https://doi.org/ 10.1016/s0031-0182(03)00463-2

Alve, E. 1990. Variations in estuarine foraminiferal biofacies with diminishing oxygen conditions in Drammensfjord, SE Norway, p. 661-694. In Hemleben, C., Kaminski, M.A., Kuhnt, W., and Scott, D.B. (eds.), Paleoecology, Biostratigraphy, Paleoceanography and Taxonomy of Agglutinated Foraminifera. Kluwer Academic Publishers, The Netherlands. https://doi.org/ 10.1007/978-94-011-3350-0_23

Alve, E. and Murray, J.W. 1999. Marginal marine environments of the Skagerrak and Kattegat: a baseline study of living (stained) benthic foraminiferal ecology. Palaeogeography, Palaeoclimatology, Palaeoecology, 146:171-193. https://doi.org/10.1016/s00310182(98)00131-x

Amore, O., Barra, D., Ciampo, G., Ruggiero Taddei, E., Russo, G.F., and Sgarrella, F. 1988. II terrazzo de La Starza: associazioni fossili e batimetria. Memorie della Società Geologica Italiana, 41:969-981.

Amore, O., Barra, D., Ciampo, G., Ruggiero Taddei, E., Russo, G.F., and Sgarrella, F. 1990. Paleoecologia dei depositi terrazzati de La Starza (Pozzuoli), p. 455-499. In Atti del Quarto 
Simposio di Ecologia e Paleoecologia delle Comunità Bentoniche, Museo Regionale di Scienze Naturali, Torino.

Andersen, H.V. 1952. Buccella, a new genus of the rotalid Foraminifera. Journal of the Washington Academy of Sciences, 42:143-151.

Angell, R.W. 1979. Calcification during chamber development in Rosalina floridana. Journal of Foraminiferal Research, 9(4):341-353. https://doi.org/10.2113/gsjfr.9.4.341

Armynot du Châtelet, E. and Debenay, J-P. 2010. The anthropogenic impact on the western French coasts as revealed by Foraminifera: a review. Revue de micropaléontologie, 53:129137. https://doi.org/10.1016/j.revmic.2009.11.002

Armynot du Châtelet, E., Debenay, J-P., and Soulard, R. 2004. Foraminiferal proxies for pollution monitoring in moderately polluted harbors. Environmental Pollution, 127:27-40. https:// doi.org/10.1016/s0269-7491(03)00256-2

Athersuch, J. 1976. On Sagmatocythere napoliana (Puri). Stereo-Atlas Ostracod Shells, 3:117124.

Athersuch, J. 1977. On Cytheretta adriatica. Stereo-Atlas Ostracod Shells, 4:69-78.

Athersuch, J. 1978a. On Pterygocythereis siveteri. Stereo-Atlas Ostracod Shells, 5:1-8.

Athersuch, J. 1978b. On Pterygocythereis jonesii. Stereo-Atlas Ostracod Shells, 5:9-16.

Athersuch, J. 1978c. The genus Xestoleberis (Crustacea: Ostracoda) with particular reference to recent Mediterranean species. Pubblicazioni della Stazione Zoologica di Napoli (1976), 40:282-343.

Athersuch, J. 1979a. On Acanthocythereis hystrix (Reuss). Stereo-Atlas Ostracod Shells, 6:133140.

Athersuch, J. 1979b. On Loxoconcha ovulata (Costa). Stereo-Atlas Ostracod Shells, 6:141-150.

Athersuch, J., 1982, Some ostracod genera formerly of the Family Cytherideidae Sars, p. 231275. In Bate, R.H. Robinson, E., and Sheppard, L.M. (eds.), Fossil and Recent Ostracods. Ellis Horwood, Chichester.

Athersuch, J., Horne, D.J., and Whittaker, J.E. 1989. Marine and Brackish Water Ostracods. In Kermack, D.M. and Barnes, R.S.K. (eds.), Synopses of the British Fauna (New Series), 43:1343.

Athersuch, J. and Whittaker, J.E. 1977. On Callistocythere badia (Norman). Stereo-Atlas Ostracod Shells, 4:53-58.

Athersuch, J. and Whittaker, J.E. 1980. On Callistocythere littoralis (G.W. Müller). Stereo-Atlas Ostracod Shells, 7:61-66.

Athersuch, J. and Whittaker, J.E. 1987. On Carinocythereis whitei (Baird). Stereo-Atlas Ostracod Shells, 14:103-110.

Avnaim-Katav, S., Almogi-Labin, A., Sandler, A., and Sivan, D. 2013. Benthic foraminifera as palaeoenvironmental indicators during the last million years in the eastern Mediterranean inner shelf). Palaeogeography, Palaeoclimatology, Palaeoecology, 386:512-530. https:// doi.org/10.1016/j.palaeo.2013.06.019

Avnaim-Katav, S., Hyams-Kaphzan, O., Milker, Y., and Almogi-Labin, A. 2015. Bathymetric zonation of modern shelf benthic foraminifera in the Levantine Basin, eastern Mediterranean Sea. Journal of Sea Research, 99:97-106. https://doi.org/10.1016/j.seares.2015.02.006

Baird, W. 1850. The Natural History of the British Entomostraca. Ray Society, London. https:// doi.org/10.5962/bhl.title.1807

Bakir, A.K., Kata?an, T., Aker, H.V., Özcan, T., Sezgin, M., Ate?, A.S., Koçak, C., and Kirkim, F. 2014. The marine arthropods of Turkey. Turkish Journal of Zoology, 38:765-831. https:// doi.org/10.3906/zoo-1405-48

Balassone, G., Aiello, G., Barra, D., Cappelletti, P., De Bonis, A., Donadio, C., Guida, M., Melluso, L., Morra, V., Parisi, R., Pennetta, M., and Siciliano, A. 2016. Effects of anthropogenic activities in a Mediterranean coastland: the case study of the Falerno-Domitio littoral in Campania, Tyrrhenian Sea (southern Italy). Marine Pollution Bullettin, 112:271-290. https://doi.org/10.1016/j.marpolbul.2016.08.004

Banner, F.T. and Culver, S.J. 1978. Quaternary Haynesina n. gen. and Paleogene Protoelphidium Haynes; their morphology, affinities and distribution. Journal of Foraminiferal Research, 8:177-207. https://doi.org/10.2113/gsjfr.8.3.177

Barbeito-Gonzalez, P.J. 1971. Die Ostracoden des Küstenbereiches von Naxos (Griechenland) und ihre Lebensbereiche. Mitteilungen aus dem Hamburgischen Zoologischen Museum und Institut, 67:255-326. 
Barmawidjaja, D.M., van der Zwaan, G.J., Jorissen, F.J., and Puskaric, S. 1995. 150 years of eutrophication in the northern Adriatic Sea: Evidence from a benthic foraminiferal record. Marine Geology, 122:367-384. https://doi.org/10.1016/0025-3227(94)00121-z

Barra, D. 1997. The shallow water marine ostracods of Tripoli (Lybia) and their geographical distribution in the Mediterranean. Revista Española de Micropaleontología, 29:71-106.

Barras, C., Jorissen, F.J., Labrune, C., Andral, B., and Boissery, P. 2014. Live benthic foraminiferal faunas from the French Mediterranean Coast: Towards a new biotic index of environmental quality. Ecological Indicators, 36:719-743. https://doi.org/10.1016/ j.ecolind.2013.09.028

Batsch, A.I.G.C. 1791. Sechs Kupfertafeln mit Conchylien des Seesanders, gezeichnet und gestochen von A.J.G.K. Batsch. Jena.

Bellini, R. 1929. Nuove osservazioni sulla malacofauna fossile flegrea. Bollettino della Società Geologica Italiana, 48:50-58.

Bellucci, F., Woo, J., Kilburn, C.R.J., and Rolandi, G. 2006. Ground deformation at Campi Flegrei, Italy: implications for hazard assessment. In Troise, C., De Natale, G., and Kilburn, C.R.J. (eds.), Mechanisms of activity and unrest at large calderas. Geological Society, Special Publications 269:141-158. https://doi.org/10.1144/gsl.sp.2006.269.01.09

Bentov, S. and Erez, J. 2006. Impact of biomineralization processes on the Mg content of foraminiferal shells: A biological perspective. Geochemistry Geophysics Geosystems, 7:1-11. https://doi.org/10.1029/2005gc001015

Bergin, F., Kucuksezgin, F., Uluturhan, E., Barut, I.F., Meric, E., Avsar, N., and Nazik, A. 2006. The response of benthic foraminifera and ostracoda to heavy metal pollution in Gulf of Izmir (Eastern Aegean Sea). Estuarine, Coastal and Shelf Science, 66:368-386. https://doi.org/ 10.1016/j.ecss.2005.09.013

Berkeley, A., Perry, C.T., Smithers, S.G., Horton, B.P., and Taylor, K.G. 2007. A review of the ecological and taphonomic controls on foraminiferal assemblage development in intertidal environments. Earth-Science Reviews, 83:205-230. https://doi.org/10.1016/ j.earscirev.2007.04.003

Bermudez, P.J. 1949. Tertiary smaller foraminifera of the Dominican Republic. Special Publications from the Cushman Laboratory for Foraminiferal Research, 25:1-322.

Berthelin, G. 1881. Coup d'oeil sur la faune rhizopodique du Calcaire Grossier Infe?rieur de la Marne. Compte rendu de l'Association Franc?aise pour l'Avancement des Sciences, 9:553559.

Berthois, L. and Le Calvez, Y. 1959. Deuxième contribution à l'étude de la sédimentation dans le Golfe de Gascogne. Revue des Travaux de l'Institut des Peches Maritimes, 23:323-377.

Blake, C.H. 1933. Order Ostracoda, p. 229-241. In Proctor, W. (ed.), Biological survey of the Mount Desert Region (5). The Wistar Institute of Anatomy \& Biology, Philadelphia.

Boatta, F., D’Alessandro, W., Gagliano, A.L., Liotta, M., Milazzo, M., Rodolfo-Metalpa, R., HallSpencer, J.M., and Parello, F. 2013. Geochemical survey of Levante Bay, Vulcano Island (Italy), a natural laboratory for the study of ocean acidification. Marine Pollution Bulletin, 73:485-494. https://doi.org/10.1016/j.marpolbul.2013.01.029

Bodergat, A.-M., Ikeya, N., and Irzi, Z. 1998. Domestic and industrial pollution: use of ostracods (Crustacea) as sentinels in the marine coastal environment. Journal de Recherche Océanographique, 23:139-144.

Boltovskoy, E., Giussani, G., Watanabe, S., and Wright, R.C. 1980. Atlas of Benthic Shelf Foraminifera of the Southwest Atlantic. Dr W. Junk bv Publishers, The Hague-BostonLondon. https://doi.org/10.1007/978-94-009-9188-0

Bonaduce, G., Ciampo, G., and Masoli, M. 1976a. Distribution of Ostracoda in the Adriatic Sea. Pubblicazioni della Stazione Zoologica di Napoli, 40(Supplement 1):1-304.

Bonaduce, G., Masoli, M., and Pugliese, N. 1977. Ostracodi bentonici dell'alto Tirreno. Studi Trentini di Scienze Naturali, Acta Biologica, 54:243-261.

Bonaduce, G., Masoli, M., and Pugliese, N. 1988. Remarks on the benthic Ostracoda on the Tunisian Shelf. In Hanai, T., Ikeya, N., and Ishizaki, K. (eds.), Evolutionary biology of Ostracoda its fundamentals and applications. Proceedings of the Ninth International Symposium on Ostracoda, held in Shizuoka, Japan 29 July - 2 August 1985. Developments in Palaeontology and Stratigraphy, 11:449-466. https://doi.org/10.1016/s09205446(08)70201-2 
Bonaduce, G. and McKenzie, K.G. 2004. Soft anatomies of some Ostracoda from the Bay of Naples described by professor Giuliano Ruggieri and other workers. Bollettino della Società Paleontologica Italiana, 43:101-112.

Bonaduce, G., Pugliese, N., and Minichelli, G. 1976b. Buntonia subulata Ruggieri (Ostracoda) in the Gulf of Naples. Pubblicazioni della Stazione Zoologica di Napoli, 40:429-432.

Bosquet, J.A.H. 1852. Description des Entomostracés fossiles des terrains tertiaires de la France et de la Belgique. Memoires Couronnes et Memoires des Savants Etrangers Publies par l'Academie Royale des Sciences, des Lettres et des Beaux-Arts de Belgique, 24:1-142.

Boudouresque, C.F., Bernard, G., Bonhomme, P., Charbonnel, E., Diviacco, G., Meinesz, A., Pergent, G., Pergent-Martini, C., Ruitton, S., and Tunesi, L. 2006. Préservation et conservation des herbiers à Posidonia oceanica. Ramoge, Marseille.

Brady, G.S. 1868. Contribution to the study of the Entomostraca. 3: Marine Ostracoda from Tenedos. Annals and Magazine of Natural History, (Series 4), 2:220-225.

Brady, G.S., Crosskey, H.W., and Robertson, D. 1874. A Monograph of the Post-Tertiary Entomostraca of Scotland Including Species from England and Ireland. Annual Volumes (Monographs) of the Palaeontographical Society (28), London. https://doi.org/10.5962/ bhl.title.84825

Brady, G.S. and Robertson, D. 1874. Contributions to the study of the Entomostraca. No. 9. On the Ostracoda taken amongst the Scilly Isles, and on the anatomy of Darwinula stevensoni. Annals and Magazine Natural history, (Series 4), 13:114-119. https://doi.org/10.1080/ 00222937308680724

Brady, H.B. 1881. Notes on some reticularian Rhizopoda of the "Challenger" expedition, Part III. Quaternary Journal of Microscopical Science, (New Series), 21:31-71.

Brady, H.B. 1884. Report on the Foraminifera dredged by H.M.S. Challenger during the years 1873-1876. Report on the scientific results of the voyage of H.M.S. Challenger during the years 1873-1876. Zoology, 9:1-814.

Breman, E. 1976. The Distribution of Ostracodes in the Bottom Sediments of the Adriatic Sea. Academisch Proefschrift. Vrije Universiteit te Amsterdam.

Brünnich, M.T. 1772. Zoologiae Fundamenta. Praelectionibus Academicis Accommodata. Grunde i Dyreloeren, Hafniae et Lipsiae. https://doi.org/10.5962/bhl.title.42672

Buchner, P. 1940. Die Lagenen des Golfes von Neapel und der marinen Albagerungen auf Ischia (Beitrage zur Naturgeschichte der Insel Ischia 1). Nova Acta Leopoldina, (New Series), 9:363-560.

Cabral, M.C. and Loureiro, I.M. 2013. Overview of Recent and Holocene ostracods (Crustacea) from brackish and marine environments of Portugal. Journal of Micropalaeontology, 32:135159. https://doi.org/10.1144/jmpaleo2012-019

Carbonnel, G. 1966. Essai d'étude statistique à propos d'un nouveau genre d'ostracode Pseudopsammocythere. Revue de Micropaléontologie, 9:50-54.

Chan, B.K.K., Wang, T.-W., Chen, P.-C., Lin, C.-W., Chan, T.-Y., and Tsang, L.M. 2016. Community structure of macrobiota and environmental parameters in shallow water hydrothermal vents off Kueishan Island, Taiwan. PLoS ONE, 11(2):e0148675. https://doi.org/ 10.1371/journal.pone.0148675

Chapman, F., Parr, W.J., and Collins, A.C. 1934. Tertiary Foraminifera of Victoria, Australia. The Balcombian deposits of Port Phillip, Part III. Journal of the Linnaean Society of London, Zoology, 38:553-577. https://doi.org/10.1111/j.1096-3642.1934.tb00996.x

Ciampo, G. 2004. Measurement of the uplift of the La Starza Marine Terrace (Pozzuoli - Italy) by ostracod assemblages. Bollettino della Società Paleontologica Italiana, 43:123-128.

Cicha, I., Rögl, F., Rupp, C., and Ctyroka, J. 1998. Oligocene - Miocene Foraminifera of the Central Paratethys. Abhandlungen der senckenbergischen naturforschenden Gesellschaft, 549:1-325.

Cigliano, M., Gambi, M.C., Rodolfo-Metalpa, R., Patti, F.P., and Hall-Spencer, J.M. 2010. Effects of ocean acidification on invertebrate settlement at volcanic $\mathrm{CO}_{2}$ vents. Marine Biology, 157:2489-2502. https://doi.org/10.1007/s00227-010-1513-6

Cinque, A., Rolandi. G., and Zamparelli, V. 1985. L'estensione dei depositi marini olocenici nei Campi Flegrei in relazione alla vulcano-tettonica. Bollettino della Società Geologica Italiana, 104:327-348.

Coccioni, R., Frontalini, F., Marsili, A., and Mana, D. 2009. Benthic foraminifera and trace element distribution: A case-study from the heavily polluted lagoon of Venice (Italy). Marine Pollution Bulletin, 59:257-267. https://doi.org/10.1016/j.marpolbul.2009.08.009 
Colom, G. 1942. Una contribución al conocimiento de los foraminíferos de la Bahía de Palma de Mallorca. Notas y Resúmenes, Instituto Español de Oceanografia, 108:1-53.

Colom, G. 1956. Los foramini?feros del Burdigaliense de Mallorca. Memorias de la Real Academia del Ciencias y Artes de Barcelona, 32:7-140.

Costa, A., Folch, A., Macedonio, G., Giaccio, B., Isaia, R., and Smith, V.C., 2012. Quantifying volcanic ash dispersal and impact of the Campanian Ignimbrite super-eruption. Geophysical Research Letters, 39: L10310. doi:10.1029/2012GL051605. https://doi.org/10.1029/ 2012gl051605

Costa, O.G. 1853a. Sopra un erpetolite idrotermale con appendice di osservazioni intorno a' depositi di avanzi organici a piè di Monte Nuovo presso Pozzuoli, e nelle marne argillose dell'isola d'Ischia. Rendiconto delle Tornate dell'Accademia Pontaniana, 1:65-88.

Costa, O.G. 1853b. Osservazioni ulteriori intorno ai fossili organici di Pozzuoli. Rendiconto delle Tornate dell'Accademia Pontaniana, 1:139-145.

Costa, O.G. 1853c. Paleontologia del Regno di Napoli: Ordine IV, de' Cipridei. [reprinted in] Atti dell'Accademia Pontaniana (1864), 8:157-192.

Costa, O.G. 1856. Paleontologia del Regno di Napoli, Parte II. Atti dell'Accademia Pontaniana, 7:113-378.

Cushman, J.A. 1922. Shallow water Foraminifera of the Tortugas region. Carnegie Institution of Washington, Department of Marine Biology, 311:1-85.

Cushman, J.A. 1923. The Foraminifera of the Atlantic Ocean. Part 4. Lagenidae. United States National Museum Bulletin, 104:1-228. https://doi.org/10.5479/si.03629236.104.3

Cushman, J.A. 1926. Recent Foraminifera from Porto Rico. Carnegie Institution of Washington Publications, 344:73-84.

Cushman, J.A. 1927. An outline of a re-classification of the Foraminifera. Contributions from the Cushman Laboratory for Foraminiferal Research, 3:1-105.

Cushman, J.A. 1933. The Foraminifera of the tropical Pacific collections of the "Albatross", 18991900. Part 2. Lagenidae to Alveolinellidae. Bulletin of the United States National Museum, 161:1-79. https://doi.org/10.5479/si.03629236.161.2

Cushman, J.A. 1936. New genera and species of the families Verneuilinidae and Valvulinidae and of the subfamily Virgulininae. Cushman Laboratory for Faminiferal Research, Special Publication, 6:1-71.

Cushman, J.A. 1944. Foraminifera from the shallow water of the New England coast. Cushman Laboratory for Foraminiferal Research, Special Publication, 12:1-37.

Cushman, J.A. and Edwards, P.G. 1937. Astrononion a new genus of the Foraminifera, and its species. Contributions from the Cushman Laboratory for Foraminiferal Research, 13:29-36.

Cushman, J.A. and Martin, L.T. 1935. A new genus of Foraminifera, Discorbinella, from Monterey Bay, California. Contributions from the Cushman Laboratory for Foraminiferal Research, 11:89-90.

Cushman, J.A. and Ozawa, Y. 1930. A monograph of the foraminiferal family Polymorphinidae, recent and fossil. Proceedings of the U.S. National Museum, 77:1-185. https://doi.org/ 10.5479/si.00963801.77-2829.1

Cushman, J.A. and Parker, F.L. 1936. Some species of Robertina. Contributions from the Cushman Laboratory for Foraminiferal Research, 12:92-100.

Dando, P.R. 2010. Biological communities at marine shallow-water vent and seep sites. In Kiel, S. (ed.), The Vent and Seep Biota, Topics in Geobiology, 33:333-478. https://doi.org/ 10.1007/978-90-481-9572-5_11

Dando, P.R., Stüben, D., and Varnavas, S.P. 1999. Hydrothermalism in the Mediterranean Sea. Progress in Oceanography, 44:333-367. https://doi.org/10.1016/s0079-6611(99)00032-4

Davidsson, S. 2014. The Distribution of the Benthic Foraminiferal Fauna in the Gullmar Fjord Deep Basin, at Station AE73142B: A Comparison with Hydrographic Parameters and the North Atlantic Oscillation. Bachelor of Science thesis, Faculty of Science, University of Gothenburg.

De Angelis d'Ossat, G. 1894. II Pozzo artesiano di Marigliano (1882). Studio geo-paleontologico. Atti della Accademia Gioenia di Scienze naturali in Catania, (Series 4), 7:1-50.

Debenay, J.-P. 2012. A Guide to 1,000 Foraminifera from Southwestern Pacific. New Caledonia. IRD Éditions, Institut de Recherche pour le Développement, Marseille, Publications Scientifiques du Muséum, Muséum national d'Histoire naturelle, Paris.

Debenay, J.P., Bénéteau, E., Zhang, J., Stouff, V., Geslin, E., Redois, F., and FernandezGonzalez, M. 1998. Ammonia beccarii and Ammonia tepida (Foraminifera): 
morphofunctional arguments for their distinction. Marine Micropaleontology, 34:235-244. https://doi.org/10.1016/s0377-8398(98)00010-3

Debenay, J-P., Geslin, E., Eichler, B.B., Duleba, W., Sylvestre, F., and Eichler, P. 2001a. Foraminiferal assemblages in a hypersaline lagoon, Araruama (RJ) Brazil. Journal of Foraminiferal Research, 31:133-151. https://doi.org/10.2113/0310133

Debenay, J.-P. and Guillou, J.J. 2002. Ecological transitions indicated by foraminiferal assemblages in paralic environments. Estuaries, 25:1107-1120. https://doi.org/10.1007/ bf02692208

Debenay, J.-P., Millet, B., and Angelidis, M.O. 2005. Relationships between foraminiferal assemblages and hydrodynamics in the Gulf of Kalloni, Greece. Journal of Foraminiferal Research, 35:327-343. https://doi.org/10.2113/35.4.327

Debenay, J.-P., Tsakiridis, E., Soulard, R., and Grossel, H. 2001b. Factors determining the distribution of foraminiferal assemblages in Port Joinville Harbor (lle d'Yeu, France): the influence of pollution. Marine Micropaleontology, 43:75-118. https://doi.org/10.1016/s03778398(01)00023-8

Deino, A.L., Orsi, G., de Vita, S., and Piochi, M. 2004. The age of the Neapolitan Yellow Tuff caldera-forming eruption (Campi Flegrei caldera - Italy) assessed by 40Ar/39Ar dating method. Journal of Volcanology Geothermal Research, 133:157-170. https://doi.org/ 10.1016/s0377-0273(03)00396-2

Delage, Y. and He?rouard, E. 1896. Traite? de Zoologie Concre?te, Volume 1, La Cellule et les Protozoaires. Schleicher Fre?res, Paris. https://doi.org/10.5962/bhl.title.2101

De Lorenzo, G. and Simotomai Tanakadate, H. 1915. I crateri del Monte Gauro nei Campi Flegrei. Atti della Reale Accademia delle Scienze fisiche e matematiche di Napoli, (Series 2), 16:1-51.

de Montfort, P.D. 1808. Conchyliologie Syste?matique et Classification Me?thodique des Coquilles, (Volume 1). Schoell, Paris. https://doi.org/10.5962/bhl.title.10571

De Rijk, S., Jorissen, F.J., Rohling, E.J., and Troelstra, S.R. 2000. Organic flux control on bathymetric zonation of Mediterranean benthic foraminifera. Marine Micropaleontology, 40:151-166. https://doi.org/10.1016/s0377-8398(00)00037-2

Dermitzakis, M.D. and Alafousou, P. 1987. Geological framework and observed oilseeps of Zakynthos Island: Their possible influence on the pollution of the marine environment. Thalassographica, 10:7-22.

de Vita, S., Orsi, G., Civetta, L., Carandente, A., D’Antonio, M., Deino, A., di Cesare, T., Di Vito, M.A., Fisher, R.V., Isaia, R., Marotta, E., Necco, A., Ort, M., Pappalardo, L., Piochi, M., and Southon, J. 1999. The Agnano-Monte Spina eruption (4100 years BP) in the restless Campi Flegrei caldera. Journal of Volcanology and Geothermal Research, 91:269-301. https:// doi.org/10.1016/s0377-0273(99)00039-6

De Vivo, B., Rolandi, G., Gans, P.B., Calvert, A., Bohrson, W.A., Spera, F.J., and Belkin, H.E. 2001. New constraints on the pyroclastic eruptive history of the Campanian volcanic plain (Italy). Mineralogy and Petrology, 73:47-65. https://doi.org/10.1007/s007100170010

Dias, B.B., Hart, M.B., Smart, C.W., and Hall-Spencer, J.M. 2010. Modern seawater acidification: the response of foraminifera to high- $\mathrm{CO}_{2}$ conditions in the Mediterranean Sea. Journal of the Geological Society, 167:843-846. https://doi.org/10.1144/0016-76492010-050

Di Bella, L., Ingrassia, M., Frezza, V., Chiocci, F.L., and Martorelli, E. 2016. The response of benthic meiofauna to hydrothermal emissions in the Pontine Archipelago, Tyrrhenian Sea (central Mediterranean Basin). Journal of Marine Systems, 164:53-66. https://doi.org/ 10.1016/j.jmarsys.2016.08.002

Di Napoli Alliata, E. 1952. Nuove specie di foraminiferi nel Pliocene e nel Pleistocene della zona di Castell'Arquato (Piacenza). Rivista Italiana di Paleontologia e Stratigrafia, 58:95-110.

Di Vito, M.A., Acocella, V., Aiello, G., Barra, D., Battaglia, M., Carandente, A., Del Gaudio, C., de Vita, S., Ricciardi, G.P., Ricco, C., Scandone, R., and Terrasi, F. 2016. Magma transfer at Campi Flegrei caldera (Italy) before the 1538 AD eruption. Scientific Reports, 6:32245. https:/ /doi.org/10.1038/srep32245

Di Vito, M.A., Isaia, R., Orsi, G., Southon, J., de Vita, S., D’Antonio, M., Pappalardo, L., and Piochi, M. 1999. Volcanism and deformation since 12,000 years at the Campi Flegrei caldera (Italy). Journal of Volcanology and Geothermal Research, 91:221-246. https://doi.org/ 10.1016/s0377-0273(99)00037-2 
Diz, P. and Francés, G. 2008. Distribution of live benthic foraminifera in the Ría de Vigo (NW Spain). Marine Micropaleontology, 66:165-191. https://doi.org/10.1016/ j.marmicro.2007.09.001

d'Orbigny, A. 1826. Tableau méthodique de la classe des Céphalopodes. Annales des Sciences Naturelles, 7:96-314.

d'Orbigny, A. 1839a. Foraminiféres, p. 1-224. In De la Sagra, R.M. (ed.), Histoire Physique, Politique et Naturelle de L'ile de Cuba. Bertrand, A., Paris.

d'Orbigny, A. 1839b. Foraminiféres, p. 119-146. In Barker-Webb, P. and Berthelot, S. (eds.), Histoire Naturelle des Iles Canaries (Volume 2, Part 2). Bethune, Paris. https://doi.org/ 10.5962/bhl.title.60795

d'Orbigny, A. 1839c. Foraminiferes. Voyage dans l'Amérique méridionale, 5:1-86.

d'Orbigny, A. 1846. Foraminifères fossiles du bassin Tertiaire de Vienne (Autriche). Gide et Compe, Libraires-Editeurs, Paris. https://doi.org/10.5962/bhl.title.145432

d'Orbigny, A. 1852. Prodrome de Paléontologie Stratigraphique Universelle des Animaux Mollusques \& Rayonnés, Faisant Suite au Cours Élémentaire de Paléontologie et de Géologie Stratigraphiques (Volume 3). Victor Masson, Paris. https://doi.org/10.5962/ bhl.title.45605

Dorreen, J.M. 1948. A foraminiferal fauna from the Kaiatan stage (upper Eocene) of New Zealand. Journal of Paleontology, 22:281-300.

Dubowsky, N.W. 1939. To the knowledge of the ostracod fauna of the Black Sea. Trudy Karadagskoy Biologicheskoy Stantsii, 5:1-68. [In Russian]

Eade, J.V. 1967. New Zealand recent foraminifera of the families Islandiellidae and Cassidulinidae. New Zealand Journal of Marine and Freshwater Research, 1:421-454. https:/ /doi.org/10.1080/00288330.1967.9515217

Egger, J.G. 1893. Foraminiferen aus Meeresgrundproben, gelothet von 1874 bis 1876 von S.M. Sch. Gazelle. Abhandlungen der Königlich Bayerischen Akademie der Wissenschaften, Mathematisch-Physikalische Classe, 18:193-458.

Ehrenberg, C.G. 1838. U?ber dem blossen Auge unsichtbare Kalkthierchen und Kieselthierchen als Hauptbestandtheile der Kreidegebirge. Bericht u?ber die zu Bekanntmachung geeigneten Verhandlungen der Ko?niglichen Preussischen Akademie der Wissenschaften zu Berlin (1838):192-200.

Ehrenberg, C.G. 1839. U?ber die Bildung der Kreidefelsen und des Kreidemergels durch unsichtbare Organismen. Abhandlungen der Ko?niglichen Akademie der Wissenschaften zu Berlin (1838):59-147.

Ehrenberg, C.G. 1840. Eine weitere Erläuterung des Organismus mehrerer in Berlin lebend beobachterer Polythalamien der Nordsee. Bericht über die zu Bekanntmachung geeigneten Verhandlungen der Königlichen Preussischen Akademie der Wissenschaften zu Berlin (1840):18-23.

Eichler, P.P.B., Eichler, B.B., de Miranda, L.B., Pereira, E.R.M., Kfouri, P.B.P., Pimenta, F.M., Bérgamo, A.L., and Vilela, C.G. 2003. Benthic Foraminiferal response to variations in temperature, salinity, dissolved oxygen and organic carbon, in the Guanabara Bay, Rio de Janeiro, Brazil. Anuário do Instituto de Geociências - UFRJ, 26:36-51.

Eichwald, C.E. von 1830. Zoologia Specialis (Volume 2). D.E. Eichwaldus, Vilnae. https://doi.org/ 10.5962/bhl.title.51803

Ellison, A.M. and Farnsworth, E.J. 1992. The ecology of Belizean mangrove-root fouling communities: patterns of epibiont distribution and abundance, and effects on root growth. Hydrobiologia, 247:87-98. https://doi.org/10.1007/978-94-017-3288-8_9

Elofson, O. 1941. Zur Kenntnis der marinen Ostracoden Schwedens, mit besonderer Berücksichtigung des Skageraks. Zoologiska Bidrag Fran Uppsala, 19:215-534.

Enge, A.J., Kucera, M., and Heinz, P. 2012. Diversity and microhabitats of living benthic foraminifera in the abyssal Northeast Paci?c. Marine Micropaleontology, 96-97:84-104. https://doi.org/10.1016/j.marmicro.2012.08.004

Faranda, C. and Gliozzi, E. 2008. The ostracod fauna of the Plio-Pleistocene Monte Mario succession (Roma, Italy). Bollettino della Società Paleontologica Italiana, 47:215-267.

Fichtel, L. v. and Moll, J.P.C. v. 1798. Testacea Microscopica, Aliaque Minuta ex Generibus Argonauta et Nautilus, ad Naturam Picta et Descripta (Microscopische and Andere Kleine Schalthiere aus den Geschlechtern Argonaute und Schiffer). Camesina, Wien. https:// doi.org/10.5962/bhl.title.10295 
Fillon, R. and Hunt, A. 1974. Late Pleistocene benthonic Foraminifera of the southern Champlain Sea: paleotemperature and paleosalinity indications. Maritime Sediments, 10:14-18. https:// doi.org/10.4138/1446

Fornasini, C. 1898. Intorno ad alcuni foraminiferi illustrati da O.G. Costa. Rendiconto delle sessioni della Reale Accademia delle Scienze dell'Istituto di Bologna, (New Series), 2:15-19.

Fornasini, C. 1900. Intorno ad alcuni esemplari di foraminiferi adriatici. Memorie della Reale Accademia delle Scienze dell'lstituto di Bologna, (Series 5), 8:357-402.

Frezza, V. and Carboni, M.G. 2009. Distribution of recent foraminiferal assemblages near the Ombrone River mouth (Northern Tyrrhenian Sea, Italy). Revue de micropaléontologie, 52:4366. https://doi.org/10.1016/j.revmic.2007.08.007

Frezza, V. and Di Bella, L. 2015. Distribution of recent ostracods near the Ombrone River mouth (Northern Tyrrhenian Sea, Italy). Micropaleontology, 61:101-114.

Frogner, P., Gi?slason, S.R., and O?skarsson, N., 2001. Fertilizing potential of volcanic ash in ocean surface water. Geology, 29:487-490. https://doi.org/10.1130/00917613(2001)029\%3C0487:fpovai\%3E2.0.co;2

Frontalini, F. and Coccioni, R. 2008. Benthic Foraminifera for heavy metal pollution monitoring: a case study from the central Adriatic Sea coast of Italy. Estuarine, Coastal and Shelf Science, 76:404-417. https://doi.org/10.1016/j.ecss.2007.07.024

Frontalini, F. and Coccioni, R. 2011. Benthic foraminifera as bioindicators of pollution: a review of Italian research over the last three decades. Les foraminifères benthiques bio-indicateurs de pollution: bilan de 30 années de recherches italiennes. Revue de micropaléontologie, 54:115-127. https://doi.org/10.1016/j.revmic.2011.03.001

Gabel, B. 1971. Die Foraminiferen der Nordsee. Helgoländer wissenschaftliche Meeresuntersuchungen, 22:1-65. https://doi.org/10.1007/bf01611364

Galloway, J.J. 1933. A Manual of Foraminifera. Principia Press, Bloomington.

Gandhi, M.S., Jisha, K., Jeshma, P., and Tharun, R. 2017. Foraminiferal and sediment geochemistry studies in and around Cochin backwaters, southwest coast of India. Indian Journal of Geo Marine Sciences, 46:2303-2313.

Garcias-Bonet, N., Marbà, N., Holmer, M., and Duarte, C.M. 2008. Effects of sediment sulfides on seagrass Posidonia oceanica meristematic activity. Marine Ecology Progress Series, 372:1-6. https://doi.org/10.3354/meps07714

Giaccio, B., Isaia, R., Fedele, F.G., Di Canzio, E., Hoffecker, J., Ronchitelli, A., Sinitsyn, A.A., Anikovich, M., Lisitsyn, S.N., and Popov, V.V. 2008. The Campanian Ignimbrite and Codola tephra layers: two temporal/stratigraphic markers for the Early Upper Palaeolithic in southern Italy and eastern Europe. Journal of Volcanology and Geothermal Research, 177:208-226. https://doi.org/10.1016/j.jvolgeores.2007.10.007

Giudicepietro, F. 1993. La Dinamica Recente dell'Area Vulcanica Flegrea. PhD thesis, University of Naples Federico II, Naples, Italy.

Glaessner, M.F. 1937. Die Entfaltung der Foraminiferenfamilie Buliminidae. Problemy Paleontologii, Paleontologicheskaya Laboratoriya Moskovskogo Gosudarstvennogo Universiteta, 2-3:411-422.

Goineau, A., Fontanier, C., Jorissen, F.J., Lansard, B., Buscail, R., Mouret, A., Kerhervé, P., Zaragosi, S., Ernoult, E., Artéro, C., Anschutz, P., Metzger, E., and Rabouille, C. 2011. Live (stained) benthic foraminifera from the Rhône Prodelta (Gulf of Lion, NW Mediterranean): environmental controls on a river-dominated shelf. Journal of Sea Research, 65:58-75. https://doi.org/10.1016/j.seares.2010.07.007

Goldstein, S.T. and Barker, W.W. 1988. Test ultrastructure and taphonomy of the monothalamous agglutinated foraminifer Cribrothalammina n. gen., alba (Heron-Allen and Earland). Journal of Foraminiferal Research, 18:130-136. https://doi.org/10.2113/ gsjfr.18.2.130

Guernet, C., Lemeille, F., Sorel, D., Bourdillon, C., Berge-Thierry, C., and Manakou, M. 2003. Les ostracodes et le Quaternaire d'Aigion (golfe de Corinthe, Grèce). Revue de micropaléontologie, 46:73-93. https://doi.org/10.1016/s0035-1598(03)00013-8

Haake, F.W. 1977. Living benthic Foraminifera in the Adriatic sea: influence of water depth and sediment. The Journal of Foraminiferal Research, 7:62-75. https://doi.org/10.2113/ gsjfr.7.1.62

Haeckel, E. 1894. Systematische Phylogenie. Entwurf eines Natu?rlichen Systems der Organismen auf Grund ihrer Stammesgeschichte, Theil 1, Systematische Phylogenie der Protisten und Pflanzen. Georg Reimer, Berlin. 
Hageman, J. 1979. Benthic foraminiferal assemblages from Plio-Pleistocene open bay to lagoonal sediments of the Western Peloponnesus (Greece). Utrecht Micropaleontological Bulletins, 20:1-171.

Hall-Spencer, J.M., Rodolfo-Metalpa, R., Martin, S., Ransome, E., Fine, M., Turner, S.M., Rowley, S.J., Tedesco, D., and Buia, M.C. 2008. Volcanic carbon dioxide vents show ecosystem effects of ocean acidification. Nature, 454:96-99. https://doi.org/10.1038/ nature 07051

Hammer, Ø. 1999-2016. PAST PAleontological STatistics. Natural History Museum, University of Oslo. http://folk.uio.no/ohammer/past

Hammer, Ø., and Harper, D.A.T. 2006. Palaeontological Data Analysis. Blackwell Publishing, Malden. https://doi.org/10.1002/9780470750711

Hammer, Ø., Harper, D.A.T., and Ryan, P.D. 2001. Past: paleontological statistics software package for education and data analysis. Palaeontologia Electronica, 4.1.4A:1-9. http://palaeo-electronica.org/2001_1/past/issue1_01.htm

Hanai, T. 1957. Studies on the Ostracoda from Japan, 1. Subfamily Leptocytherinae, n. subfam. Journal of the Faculty of Science, University of Tokyo, Section 2, 10: 431-468.

Hansen, H.J. and Revets, R. 1992. A revision and reclassification of the Discorbidae, Rosalinidae, and Rotaliidae. Journal of Foraminiferal Research, 22:166-180. https://doi.org/ 10.2113/gsjfr.22.2.166

Harzhauser, M., Theobalt, D., Strauss, P., Mandic, O., Carnevale, G., and Piller, W.E. 2017. Miocene biostratigraphy and paleoecology of the Mistelbach Halfgraben in the northwestern Vienna Basin (Lower Austria). Jahrbuch der Geologischen Bundesanstalt, 157:57-108.

Hasegawa, S., Sprovieri, R., and Poluzzi, A. 1990. Quantitative analysis of benthic foraminiferal assemblages from Plio-Pleistocene sequences in the Tyrrhenian Sea, ODP LEG 107. In Kastens, K.A., Mascle, J., Auroux, C., Bonatti, E., Broglia, C., Channell, J., Curzi, P., Emeis, K.C., Glaçon, G., Hasegawa, S., Hieke, W., McCoy, F., McKenzie, J., Mascle, G., Mendelson, J., Müller, C., Réhault, J.-P., Robertson, A., Sartori, R., Sprovieri R., and Torii, M. (eds.), Proceedings of the Ocean Drilling Program, Scientific Results, 107: 461-478. https://doi.org/ 10.2973/odp.proc.sr.107.150.1990

Haynes, J.R. 1973. Cardigan Bay Foraminifera (cruises of the R.V. Antur, 1962-1964). Bulletin of the British Museum (Natural History), Zoology, (Supplement 4):1-245.

Hayward, B.W., Grenfell, H.R., Sabaa, A.T., Neil, H.L., and Buzas, M.A. 2010. Recent New Zealand deep-water benthic Foraminifera: taxonomy, ecologic distribution, biogeography, and use in paleoenvironmental assessment. GNS Science Monographs, 26. New Zealand Geological Survey Paleontological Bulletin, 77:1-363.

Hayward, B.W., Holzmann, M., Grenfell, H.R., Pawlowski, J., and Triggs, C.M. 2004. Morphological distinction of molecular types in Ammonia - towards a taxonomic revision of the world's most commonly misidentified foraminifera. Marine Micropaleontology, 50:237271. https://doi.org/10.1016/s0377-8398(03)00074-4

Hayward, B.W., Neil, H., Carter R., Grenfell, H.R., and Hayward, J.J. 2002. Factors influencing the distribution patterns of Recent deep-sea benthic foraminifera, east of New Zealand, Southwest Pacific Ocean. Marine Micropaleontology, 46:139-176. https://doi.org/10.1016/ s0377-8398(02)00047-6

Heron-Allen, A. and Earland, A. 1913. Clare Island Survey; Part 64 - The Foraminifera of the Clare Island District, Co.Mayo, Ireland. Proceedings of the Royal Irish Academy, 31:1-188.

Heron-Allen, E. and Earland, A. 1930. The Foraminifera of the Plymouth district. I. Journal of the Royal Microscopical Society, (Series 3), 50:46-84. https://doi.org/10.1111/j.13652818.1930.tb01475.x

Hirschmann, N. 1909. Beitrag zur Kenntnis der Ostracodenfauna des Finnischen Meerbusens. Meddelanden af Societas pro Fauna et Flora fennica, 35: 282-296.

Hoaki, T., Nishijima, M., Miyashita, H., and Maruyama, T. 1995. Dense community of hyperthermophilic sulfur-dependent heterotrophs in a geothermally heated shallow submarine biotope near Kodakara-Jima Island, Kagoshima, Japan. Applied and Environmental Microbiology, 61:1931-1937.

Hofker, J. 1951. The Foraminifera of the Expedition (Part 3). Siboga Expetitie, Monograph 4a, E.J. Brill, Leiden.

Hofker, J. 1956. Tertiary Foraminifera of coastal Ecuador. Part II. Additional notes on the Eocene species. Journal of Paleontology, 30:891-958. 
Holzmann, M. and Pawlowski, J. 2000. Taxonomic relationships in the genus Ammonia (Foraminifera) based on ribosomal DNA sequence. Journal of Micropaleontology, 19:85-95. https://doi.org/10.1144/jm.19.1.85

Hornibrook, N. de B., 1961. Tertiary Foraminifera from Oamaru District (N.Z). Part 1. Systematics and distribution. New Zealand Geological Survey Paleontological Bulletin, 34:1-194.

Horton, B.P. and Edwards, R.J. 2006. Quantifying Holocene sea level change using intertidal Foraminifera: lessons from the British Isles. Cushman Foundation for Foraminiferal Research, Special Publication, 40:1-97.

Howe, R.C. 1963. Type saline Bayou Ostracoda of Lousiana. Geological Bulletin, Louisiana Geological Survey, 40:1-62.

Husezima, R. and Maruhasi, M. 1944. A new genus and thirteen new species of Foraminifera from the core-sample of Kashiwazaki oil field, Niigata-ken. Journal Sigenkagaku Kenkyusho, 1:391-400.

Ingrassia, M., Di Bella, L., Chiocci, F.L., and Martorelli, E. 2015a. Influence of fluid emissions on shallow-water benthic habitats of the Pontine Archipelago (Tyrrhenian Sea, Italy). Alpine and Mediterranean Quaternary, 28:99-110.

Ingrassia, M., Martorelli, E., Bosman, A., Macelloni, L., Sposato, A., and Chiocci, F.L. 2015b. The Zannone Giant Pockmark: first evidence of a giant complex seeping structure in shallowwater, central Mediterranean Sea, Italy. Marine Geology, 363:38-51. https://doi.org/10.1016/ j.margeo.2015.02.005

Isaia, R., Ciarcia, S., Iannuzzi, E., Prinzi, E., Tramparulo, F.D'A., and Vitale, S. 2016. The interplay between deformation and volcanic activity: new data from the central sector of the Campi Flegrei caldera. Geophysical Research Abstracts, 18 EGU2016-5808.

Isaia, R., Marianelli, P., and Sbrana, A. 2009. Caldera unrest prior to intense volcanism in Campi Flegrei (Italy) at 4.0 ka B.P.: implications for caldera dynamics and future eruptive scenarios. Geophysical Research Letters, 36:L21303. https://doi.org/10.1029/2009gl040513

Isaia, R., Vitale, S., Di Giuseppe, M.G., Iannuzzi, E., Tramparulo, F.D'A., and Troiano, A. 2015. Stratigraphy, structure and volcano-tectonic evolution of Solfatara maar-diatreme (Campi Flegrei, Italy). Geological Society of America Bulletin, 127:1485-1504. https://doi.org/ 10.1130/b31183.1

Javaux, E.J. and Scott, D.B. 2003. Illustration of modern benthic Foraminifera from Bermuda and remarks on distribution in other subtropical/tropical areas. Palaeontologia Electronica 6.1.4A:1-29. palaeo-electronica.org/2003_1/benthic/issue1_03.htm

Jones, T.R. 1875. Buliminida, p. 320. In Griffith, J.W. and Henfrey, A. (eds.) 1875, The Micrographic Dictionary (Volume 1, 3rd Edition). Van Voorst, London. https://doi.org/10.5962/ bhl.title.63328

Jorissen, F.J. 1987. The distribution of benthic foraminifera in the Adriatic Sea. Marine Micropaleontology, 12:21-48. https://doi.org/10.1016/0377-8398(87)90012-0

Jorissen, F.J. 1988. Benthic Foraminifera from the Adriatic Sea. Principles of phenotypic variation. Utrecht Micropaleontologcal Bulletin, 37:1-176.

Jorissen, F.J., Fontanier, C., and Thomas, E. 2007. Paleoceanographical proxies based on deep-sea benthic foraminiferal assemblage characteristics. In Hillaire-Marcel, C. and de Vernal, A. (eds.), Proxies in Late Cenozoic Paleoceanography. Developments in Marine Geology, 1: 263-325. https://doi.org/10.1016/s1572-5480(07)01012-3

Kamenev, G.M., Fadeev, V.I., Selin, N.I., Tarasov, V.G., and Malakhov, V.V. 1993. Composition and distribution of macro and meiobenthos around sublittoral hydrothermal vents in the Bay of Plenty, New Zealand. New Zealand Journal of Marine and Freshwater Research, 27:407418. https://doi.org/10.1080/00288330.1993.9516582

Kaminski, M.A., Aku, A., Box, M., Hiscott, R.N., Filipescu, S., and Al-Salameen, M. 2002. Late Glacial to Holocene benthic foraminifera in the Marmara Sea: implications for Black Sea Mediterranean Sea connections following the last deglaciation. Marine Geology, 190:162202. https://doi.org/10.1016/s0025-3227(02)00347-x

Karlen, D.J., Price, R.E., Pichler, T., and Garey, J.R. 2010. Changes in benthic macrofauna associated with a shallow-water hydrothermal vent gradient in Papua New Guinea. Pacific Science, 64:391-404. https://doi.org/10.2984/64.3.391

Karlsen, A.W., Cronin, T.M., Ishman, S.E., Willard, D.A., Kerhin, R., Holmes, C.W., and Marot, M. 2000. Historical trends in Chesapeake Bay dissolved oxygen based on benthic foraminifera from sediment cores. Estuaries, 23:488-508. https://doi.org/10.2307/1353141 
Kiel, S. (ed.), 2010. The Vent and Seep Biota. Topics in Geobiology 33. Springer, Dordrecht. https://doi.org/10.1007/978-90-481-9572-5

Klie, W. 1936. Ostracoden der Familie Cytheridae aus Sand und Schell von Helgoland. Kieler Meeresforschungen, 1:49-72.

Kollmann, K. 1960. Cytherideinae und Schulerideinae n. subfam. (Ostracoda) aus dem Neogen des Oestlichen Oesterreich. Mitteilungen der Geologischen Gesellschaft in Wien, 51:89-195.

Krautter, M. 1998. Ecology of siliceous sponges. Application to the environmental interpretation of the Upper Jurassic sponge facies (Oxfordian) from Spain. Cuadernos de Geología Ibérica, 24:223-239.

Kubanç, S.N. 2005. Diversity and comparison of Ostracoda of South Marmara Sea. Journal of the Black Sea/Mediterranean Environment, 12:17-34.

Kuhnt, T., Schmiedl, G., Ehrmann, W., Hamann, Y., and Hemleben, C. 2007. Deep-sea ecosystem variability of the Aegean Sea during the past $22 \mathrm{kyr}$ as revealed by benthic Foraminifera. Marine Micropaleontology, 64:141-162. https://doi.org/10.1016/ j.marmicro.2007.04.003

Lachenal, A.M. 1989. Écologie des Ostracodes du Domaine Méditerranéen: Application au Golfe de Gabès (Tunisie Orientale). Les Variations du Niveau Marin Depuis 30000 Ans. Documents des Laboratoires de Géologie de Lyon, 108.

Lamarck, J.B. 1804. Suite des mémoires sur les fossils des environs de Paris. Annales Muséum National d'Histoire Naturelle, 5:179-188.

Lambeck, K., Antonioli, F., Anzidei, M., Ferranti, L., Leoni, G., Scicchitano, G., and Silenzi, S. 2011. Sea level change along the Italian coast during the Holocene and projections for the future. Quaternary International, 232:250-257. https://doi.org/10.1016/j.quaint.2010.04.026

Langlet, D., Baal, C., Geslin, E., Metzger, E., Zuschin, M., Riedel, B., Risgaard-Petersen, N., Stachowitsch, M., and Jorissen, F.J. 2014. Foraminiferal species responses to in situ, experimentally induced anoxia in the Adriatic Sea. Biogeosciences, 11:1775-1797. https:// doi.org/10.5194/bg-11-1775-2014

Latreille, P.A. 1802. Histoire Naturelle, Générale et Particulière des Crustacés et des Insectes (Volume 4). Dufart, Paris. https://doi.org/10.5962/bhl.title.15764

Lévy, A. 1966. Contribution a l'étude écologique et micropaléontologique de quelques Elphidium (Foraminiferes) du Roussillon. Description d'une nouvelle espèce: E. cuvillieri n. sp. Vie et Milieu, 17:1-8.

Linnaeus, C. 1758. Systema Naturae per Regna Tria Naturae, Secundum Classes, Ordines, Genera, Species, cum Characteribus, Differentiis, Synonymis, Locis (Editio decima, reformata). Laurentius Salvius, Holmiae. https://doi.org/10.5962/bhl.title.542

Loeblich, A.R., Jr. and Tappan, H. 1961. Suprageneric classification of the Rhizopodea. Journal of Paleontology, 35:245-330.

Loeblich, A.R., Jr. and Tappan, H. 1964. Sarcodina, chiefly "Thecamoebians" and Foraminiferida, p. C1-C900. In Moore, R.C. (ed.), Treatise on Invertebrate Paleontology, Part C, Protista 2. Geological Society of America and University of Kansas Press, Boulder, Colorado and Lawrence, Kansas.

Loeblich, A.R., Jr. and Tappan, H. 1986. Some new and revised genera and families of hyaline calcareous Foraminiferida (Protozoa). Transactions of the American Microscopical Society, 105:239-265. https://doi.org/10.2307/3226297

Loeblich, A.R., Jr. and Tappan, H. 1989. Implications of wall composition and structure in agglutinated foraminifers. Journal of Paleontology, 63:769-777. https://doi.org/10.1017/ s0022336000036477

Loeblich, A.R., Jr. and Tappan, H. 1994. Foraminifera of the Sahul Shelf and Timor Sea. Cushman Foundation for Foraminiferal Research, Special Publication, 31:1-661.

Lowery, C.M., Leckie, R.M., and Sageman, B.B. 2017. Micropaleontological evidence for redox changes in the OAE3 interval of the US Western Interior: global vs. local processes. Cretaceous Research, 69:34-48. https://doi.org/10.1016/j.cretres.2016.08.011

?uczkowska, E. 1974. Miliolidae (Foraminiferida) from Miocene of Poland. Part II. Biostratigraphy, palaeoecology and systematics. Acta Palaeontologica Polonica, 19:3-176.

Mandelstam, M.I., 1958. In Bubikyan, S.A., Ostracoda from Paleogene deposits of the Erevan Basin. Izvestiya Akademii Nauk Armyanskoy SSSR, Seriya Geologicheskikh i Geograficheskikh Nauk, 11:3-16. [In Russian]

Mangoni, O., Aiello, G., Balbi, S., Barra, D., Bolinesi, F., Donadio, C., Ferrara, L., Guida, M., Parisi, R., Pennetta, M., Trifuoggi, M., and Arienzo, M. 2016. A multidisciplinary approach for 
the characterization of the coastal marine ecosystems of Monte Di Procida (Campania, Italy). Marine Pollution Bulletin, 112:443-451. https://doi.org/10.1016/j.marpolbul.2016.07.008

Margerel, J.P. 1970. Aubignyna, nouveau genre de foraminifères du Pliocéne du Bosq d'Aubigny (Manche). Revue de Micropaléontologie, 13:58-64.

Margreth, S., Rüggeber, A., and Spezzaferri, S. 2009. Benthic foraminifera as bioindicator for cold-water coral reef ecosystems along the Irish margin. Deep-Sea Research I, 56:22162234. https://doi.org/10.1016/j.dsr.2009.07.009

Martin, S., Rodolfo-Metalpa, R., Ransome, E., Rowley, S., Buia, M.-C., Gattuso, J.-P., and HallSpencer, J. 2008. Effects of naturally acidi?ed seawater on seagrass calcareous epibionts. Biology Letters, 4:689-692. https://doi.org/10.1098/rsbl.2008.0412

Marturano, A., Isaia, R., Aiello, G., and Barra, D., 2018. Complex dome growth at Campi Flegrei caldera (Italy) in the last $15 \mathrm{ka}$. Journal of Geophysical Research: Solid Earth, 123. https:// doi.org/10.1029/2018JB015672

Mathews, R.D. 1945. Rectuvigerina, a new genus of Foraminifera from a restudy of Siphogenerina. Journal of Paleontology, 19:588-606.

McCulloch, I. 1977. Qualitative Observations on Recent Foraminiferal Tests with Emphasis on the Eastern Pacific (Parts I-III). University of Southern California, Los Angeles.

McGowran, B. 1966. Australian Paleocene Lamarckina and Ceratobulimina with a discussion of Cerobertina, Pseudobulimina, and the family Robertinidae. Contributions from the Cushman Foundation for Foraminiferal Research, 17:77-103.

Melwani, A.R. and Kim, S.L. 2008. Benthic infaunal distributions in shallow hydrothermal vent sediments. Acta Oecologica, 33:162-175. https://doi.org/10.1016/j.actao.2007.10.008

Mikhalevich, V.I. 1981. Parallelizm i konvergentsiya v evolyutsii skeketov foraminifer. Trudy Zoologischeskogo Instituta, Akademiya Nauk SSSR, 107:19-41. [In Russian]

Milker, Y. and Schmiedl, G. 2012. A taxonomic guide to modern benthic shelf foraminifera of the western Mediterranean Sea. Palaeontologia Electronica, 15.2.16A:1-134. https://doi.org/ $10.26879 / 271$ palaeo-electronica.org/content/2012-issue-2-articles/223-taxonomy-foraminifera

Milker, Y., Schmiedl, G., Betzler, C., Römer, M., Jaramillo-Vogel, D., and Siccha, M. 2009. Distribution of recent benthic foraminifera in shelf carbonate environments of the Western Mediterranean Sea. Marine Micropaleontology, 73:207-225. https://doi.org/10.1016/ j.marmicro.2009.10.003

Minieri, V. 1950. La terrazza della Starza nei Campi Flegrei. Rendiconto dell'Accademia delle Scienze Fisiche e Matematiche, (Series 4), 17:201-212.

Möbius, K. 1880. Foraminifera von Mauritius, p. 65-137. In Möbius, K., Richters, F., and von Martens, E. (eds.), Beitra?ge zur Meeresfauna der Insel Mauritius und der Seychellen. Gutmann, Berlin. https://doi.org/10.1007/978-94-017-6608-1

Mojtahid, M., Geslin, E., Coynel, A., Gorse, L., Vella, C., Davranche, A., Zozzolo, L., Blanchet, L., Be?ne?teau, E., and Maillet, G. 2016. Spatial distribution of living (Rose Bengal stained) benthic foraminifera in the Loire estuary (western France). Journal of Sea Research, 118:116. https://doi.org/10.1016/j.seares.2016.02.003

Mojtahid, M., Griveaud, C., Fontanier, C., Anschutz, P., and Jorissen, F.J. 2010. Live benthic foraminiferal faunas along a bathymetrical transect $(140-4800 \mathrm{~m}$ ) in the Bay of Biscay (NE Atlantic). Revue de micropaléontologie, 53:139-162. https://doi.org/10.1016/ j.revmic.2010.01.002

Mojtahid, M., Jorissen, F., Durrieu, J., Galgani, F., Howa, H., Redois, F., and Camps, R. 2006. Benthic foraminifera as bio-indicators of drill cutting disposal in tropical east Atlantic outer shelf environments. Marine Micropaleontology, 61:58-75. https://doi.org/10.1016/ j.marmicro.2006.05.004

Montagu, G. 1803. Testacea Britannica or Natural History of British Shells, Marine, Land, and Fresh-Water, Including the Most Minute: Systematically Arranged and Embellished with Figures. J.S. Hollis, Romsey. https://doi.org/10.5962/bhl.title.33927

Moodley, L. and Hess, C. 1992. Tolerance of infaunal benthic Foraminifera for low and high oxygen concentrations. Biological Bulletin, 183:94-98. https://doi.org/10.2307/1542410

Moodley, L., van der Zwaan, G.J., Rutten, G.M.W., Boom, R.C.E., and Kempers, A.J. 1998. Subsurface activity of benthic foraminifera in relation to porewater oxygen content: laboratory experiments. Marine Micropaleontology, 34:91-106. https://doi.org/10.1016/s03778398(97)00044-3 
Mostafawi, N. and Matzke-Karasz, R. 2006. Pliocene Ostracoda of Cephalonia, Greece. The unrevised species of Uliczny (1969). Revista Española de Micropaleontología, 38:11-48.

Müller, G.W. 1894. Die Ostracoden des Golfes von Neapel und der angrenzenden MeeresAbschnitte. Fauna und Flora des Golfes von Neapel und der angrenzenden MeeresAbschnitte, Herausgegeben von der Zoologischen Station zu Neapel, 21:1-404.

Müller, G.W. 1912. Crustacea Ostracoda. In Schulze, F.E., Das Tierreich. Eine Zusammenstellung und Kennzeichnung der rezenten Tierformen (31) Berlin.

Murray, J.W. 1991. Ecology and Paleoecology of Benthic Foraminifera. Longman Scientific \& Technical (John Wiley), Harlow. https://doi.org/10.4324/9781315846101

Murray, J. W. 2003. An illustrated guide to the benthic Foraminifera of the Hebridean shelf, west of Scotland, with notes on their mode of life. Palaeontologia Electronica, 5.2.5A:1-31. palaeo-electronica.org/2002_2/guide/issue2_02.htm

Murray, J.W. 2006. Ecology and Applications of Benthic Foraminifera. Cambridge University Press. https://doi.org/10.1017/cbo9780511535529

Murray, J.W. 2014. Ecology and Paleoecology of Benthic Foraminifera. Routledge, New York. https://doi.org/10.4324/9781315846101

Murray, J.W., Whittaker, J.E., and Alve, E. 2000. On the type species of Aubignyna and a description of $A$. hamblensis, a new microforaminifer from temperate shallow waters. Journal of Micropaleontology, 19:61-67. https://doi.org/10.1144/jm.19.1.61

Natland, M.L. 1938. New species of Foraminifera from off the west coast of North America and from the later Tertiary of the Los Angeles basin. Bulletin of the Scripps Institution of Oceanography of the University of California, Technical Series, 4:137-163.

Neviani, A. 1928. Ostracodi fossili d'Italia. 1: Vallebiaja (Calabriano). Memorie della Pontificia Accademia della Scienze, Nuovi Lincei, (Series 2), 11:1-120.

Nomura, R. 1983. Cassidulinidae (Foraminiferida) from the uppermost Cenozoic of Japan (Part 2). Tohoku University Science Reports (Geology), (Series 2), 54:1-93.

Norman, A.M. 1862. Contributions to British carcinology. II. On species of Ostracoda new to Great Britain. Annals and Magazine Natural History, (Series 3), 9:43-52. https://doi.org/ 10.1080/00222936208681185

Oflaz, S.A. 2006. Taxonomy and Distribution of the Benthic Foraminifera in the Gulf of Iskenderun, Eastern Mediterranean. MSc. thesis, METU, Ankara.

Orsi, G., D'Antonio, M., de Vita, S., and Gallo, G. 1992. The Neapolitan Yellow Tuff, a largemagnitude trachytic phreatoplinian eruption: eruptive dynamics, magma withdrawal and caldera collapse. Journal of Volcanology Geothermal Research, 53:275-287. https://doi.org/ 10.1016/0377-0273(92)90086-s

Orsi, G., de Vita, S., and Di Vito, M.A., 1996. The restless, resurgent Campi Flegrei nested caldera (Italy): constraints on its evolution and configuration. Journal of Volcanology and Geothermal Research, 74:179-214. https://doi.org/10.1016/s0377-0273(96)00063-7

Panieri, G. 2006. The effect of shallow marine hydrothermal vent activity on benthic Foraminifera (Aeolian Arc, Tyrrhenian Sea). Journal of Foraminiferal Research, 36:3-14. https://doi.org/ 10.2113/36.1.3

Panieri, G., Aharon, P., Sen Gupta, B.K., Camerlenghi, A., Ferrer, F.P., and Cacho, I. 2014. Late Holocene foraminifera of Blake Ridge diapir: assemblage variation and stable-isotope record in gas-hydrate bearing sediments. Marine Geology, 353:99-107. https://doi.org/10.1016/ j.margeo.2014.03.020

Panieri, G., Gamberi, F., Marani, M., and Barbieri, R. 2005. Benthic foraminifera from a recent, shallow-water hydrothermal environment in the Aeolian Arc (Tyrrhenian Sea). Marine Geology, 218:207-229. https://doi.org/10.1016/j.margeo.2005.04.002

Papp, A. and Schmid, M.E. 1985. The fossil Foraminifera of the Tertiary Basin of Vienna. Revision of the monograph by Alcide d'Orbigny (1846). Abhandlungen der Geologischen Bundesanstalt, 37:1-311.

Parker, F.L., Phleger, F.B., and Peirson, J.F. 1953. Ecology of Foraminifera from San Antonio Bay and environs, Southwest Texas. Cushman Foundation for Foraminiferal Research, Special Publication, 2:1-76.

Passariello, I., Talamo, P., D'Onofrio, A., Barta, P., Lubritto, C., and Terrasi, F. 2010. Contribution of the radiocarbon dating to the chronology of Eneolithic in Campania (Italy). Geochronometria, 35:25-33. https://doi.org/10.2478/v10003-010-0008-2

Patterson, R.T. and Richardson, R.P. 1987. A taxonomic revision of the unilocular foraminifera. Journal of Foraminiferal Research, 17:212-216. https://doi.org/10.2113/gsjfr.17.3.212 
Pawlik, J.R., Mcmurray, S.E., and Henkel, T.P. 2007. Abiotic factors control sponge ecology in Florida mangroves. Marine Ecology Progress Series, 339:93-98. https://doi.org/10.3354/ meps339093

Perçin-Paçal, F. and Balkis, H. 2012. Seasonal distribution of Ostracoda in Bandirma Bay and Erdek Bay, Sea of Marmara, Turkey. Crustaceana, 85:847-875. https://doi.org/10.1163/ $156854012 \times 650791$

Pettit, L.R. 2015. The Effects of Ocean Acidification on Modern Benthic Foraminifera. Thesis, Plymouth University.

Pettit, L.R., Hart, M.B., Medina-Sánchez, A.N., Smart, C.W., Rodolfo-Metalpa, R., Hall-Spencer, J.M., and Prol-Ledesma, R.M. 2013. Benthic foraminifera show some resilience to ocean acidi?cation in the northern Gulf of California, Mexico. Marine Pollution Bulletin, 73:452-462. https://doi.org/10.1016/j.marpolbul.2013.02.011

Phipps, M.D., Kaminski, M.A., and Aksu, A.E. 2010. Calcareous benthic foraminiferal biofacies along a depth transect on the southwestern Marmara shelf (Turkey). Micropaleontology, 56:377-392.

Phleger, F.B. and Parker, F.L. 1951. Ecology of Foraminifera, Northwest Gulf of Mexico. Part II. Foraminifera species. Memoirs of the Geological Society of America, 46:1-64. https://doi.org/ 10.1130/mem46-p2-0001

Pillet, L., Fontaine, D., and Pawlowski, J. 2012. Intra-genomic ribosomal RNA polymorphism and morphological variation in Elphidium macellum suggests inter-specific hybridization in Foraminifera. PLoS ONE, 7(2):e32373. https://doi.org/10.1371/journal.pone.0032373

Pillet, L., Voltski, I., Korsun, S., and Pawlowski, J. 2013. Molecular phylogeny of Elphidiidae (Foraminifera). Marine Micropaleontology, 103:1-14. https://doi.org/10.1016/ j.marmicro.2013.07.001

Plancus, J. 1739. De Conchis Minus Notis Liber cui Accessit Specimen Aestus Reciproci Maris Superi ad Littus Portumque Arimini. Typis Joannis Baptistae Pasquali Aere Auctoris, Venetiis. https://doi.org/10.5962/bhl.title.16006

Poag, C.W. 1981. Ecologic Atlas of Benthic Foraminifera of the Gulf of Mexico. Marine Science International, Woods Hole.

Pokorný, W. 1955, Contribution to the morphology and taxonomy of the Subfamily "Hemicytherinae" Puri. Acta Universitatis Carolinae Pragae, Geologica, 3:1-35.

Polovodova, I., Nikulina, A., Schönfeld, J., and Dullo, W.-C. 2009. Recent benthic foraminifera in the Flensburg Fjord (Western Baltic Sea). Journal of Micropalaeontology, 28:131-142. https:/ /doi.org/10.1144/jm.28.2.131

Pucci, A. 1955. Ostracodi pleistocenici della Valle del Tronto. Giornale di Geologia, (Series 2), 25:163-172.

Puri, H.S. 1953. The ostracode genus Hemicythere and its allies. Journal of the Washington Academy of Sciences, 43:169-179.

Puri, H.S. 1954. Contribution to the study of the Miocene of the Florida panhandle. Bulletin of the Florida State Geological Survey, 36:1-345.

Puri, H.S. 1957. Notes on the ostracode subfamily Cytherideidinae Puri, 1952. Journal of the Washington Academy of Sciences, 47:305-306.

Puri, H.S. 1974. In Hartmann, G. and Puri, H.S. Summary of neontological and paleontological classification of Ostracoda. Mitteilungen aus dem hamburgischen zoologischen Museum und Institut, 70:7-73.

Quilty, P.G. 2010. Foraminifera from Late Pliocene sediments of Heidemann Valley, Vestfold Hills, East Antarctica. Journal of Foraminiferal Research, 40:193-205. https://doi.org/ 10.2113/gsjfr.40.2.193

Reiss, Z. 1963. Reclassification of perforate Foraminifera. Bulletin of the Geological Survey of Israel, 35:1-111.

Reuss, A.E. 1850a. Neue Foraminiferen aus den Schichten des österreichischen Tertiärbeckens. Denkschriften der kaiserlichen Akademie der Wissenschaften in Wien, mathematisch-naturwissenschaftlichen, Classe 1:365-390.

Reuss, A.E. 1850b. Die fossilen Entomostraceen des Österreichischen Tertiaerbeckens. Naturwissenschaftliche Abhandlungen 1, 3:41-92.

Reuss, A.E. 1851. Über die fossilen Foraminiferen und Entostraceen der Septarienthone der Umgebung von Berlin. Zeitschrift der Geologischen Gesellschaft, 3:49-91. 
Reuss, A.E. 1860. Die Foraminiferen der Westpha?lischen Kreideformation. Sitzungsberichte der Kaiserlichen Akademie der Wissenschaften in Wien, Mathematischnaturwissenschaftliche Classe, 40:147-238.

Reuss, A.E. 1862. Entwurf einer systematischen Zusammenstellung der Foraminiferen. Sitzungsberichte der Kaiserlichen Akademie der Wissenschaften in Wien, MathematischNaturwissenschaftliche Classe, 44:355-396.

Revets, S.A. 1996. The generic revision of five families of rotaliine Foraminifera. Part I. The Bolivinidae Cushman, 1927. Cushman Foundation for Foraminiferal Research Special Publication, 34:1-55.

Ricevuto, E., Lorenti, M., Patti, F.P., Scipione, M.B., and Gambi, M.C. 2012. Temporal trends of benthic invertebrate settlement along a gradient of ocean acidification at natural $\mathrm{CO}_{2}$ vents (Tyrrhenian Sea). Biologia Marina Mediterranea, 19:49-52.

Rodolfo-Metalpa, R., Houlbre?que, F., Tambutte?, E?., Boisson, F., Baggini, C., Patti, F.P., Jeffree, R., Fine, M., Foggo, A., Gattuso, J-P., and Hall-Spencer, J.M. 2011. Coral and mollusc resistance to ocean acidification adversely affected by warming. Nature Climate Change, 1:308-312. https://doi.org/10.1038/nclimate1200

Rodrigues, A.R., Díaz, T.L., and Pellizari, V.H. 2014. Living Foraminifera in a Brazilian subtropical coastal environment (Flamengo Inlet, Ubatuba, São Paulo State - Brazil), p. 195227. In Kitazato, H. and Bernhard, J.M. (eds.), Approaches to Study Living Foraminifera. Environmental Science and Engineering, Springer, Tokyo. https://doi.org/10.1007/978-4-43154388-6 11

Rodriquez, A. 1964. Contributo alla conoscenza delle faune fossili dei Campi Flegrei (La Starza). Bollettino della Società dei Naturalisti in Napoli, 73:100-138.

Roemer, F.A., 1838a. Cephalopoden des Nord-Deutschen tertiaren Meersandes. Neues Jahrbuch für Mineralogie, Geognosie, Geologie und Petrefaktenkunde, Stuttgart, 5:381-394

Roemer, F.A. 1838b. Die Cytherinen des Molasse-Gebirges. Neues Jahrbuch für Mineralogie, Geognosie, Geologie und Petrefaktenkunde, Stuttgart, 5:514-519.

Rome, D.R. 1942. Ostracodes marins des environs de Monaco. Bulletin Institut Océanographique. Monaco, 8:1-31.

Rosenfeld, A. 1977. Die rezenten Ostracoden-Arten in der Ostsee. Meyniana, 29:11-49.

Rosi, M. and Sbrana, A. 1987. Phlegrean Fields. CNR, Quaderni de La Ricerca Scientifica, 114:1-175.

Rouvillois, A. 1974. Un foraminifère méconnu du plateau continental du Golfe de Gascogne: Pseudoeponides falsobeccarii n.sp. Cahiérs de Micropaléontologie, 3:3-9.

Ruggieri, G. 1950. Gli ostracodi delle sabbie grigie quaternarie (Milazziano) di Imola. Parte I. Giornale di Geologia, (Series 2), 21:1-57.

Ruggieri, G. 1952. Gli ostracodi delle sabbie grigie quaternarie (Milazziano) di Imola. Parte II. Giornale di Geologia, (Series 2), 22:1-65.

Ruggieri, G. 1953. Iconografia degli ostracodi marini del Pliocene e Pleistocene italiani. Parte I. Atti Società Italiana Scienze Naturali, 92:40-56.

Ruggieri, G. 1954. Iconografia degli ostracodi marini del Pliocene e Pleistocene italiani. Parte II. Atti Società Italiana Scienze Naturali, 93:561-565.

Ruggieri, G. 1956. La suddivisione degli ostracodi già compresi nel genere Cythereis proposta da Neviani nel 1928. Atti della Societa? Italiana di Scienze Naturali, 95:161-175.

Ruggieri, G. 1959. Enumerazione degli ostracodi marini del Neogene, Quaternario e Recente italiani descritti o elencati nell'ultimo decennio. Atti della Società Italiana di Scienze Naturali e del Museo Civico di Storia Naturale in Milano, 98:183-208.

Ruggieri, G. 1975. Revisione della ostracofauna marina quaternaria di Imola (Bologna). Revista Española de Micropaleontologia, 6:419-446.

Ruggieri, G. 1978. Due ostracofaune dell'Emiliano (Pleistocene inferiore) argilloso del Subappenino di Faenza. Bollettino della Società Paleontologica Italiana, 17:3-14.

Ruggieri, G. 1991. Gli ostracodi nell'opera di Giuseppe Seguenza. Atti Accademia Peloritana dei Pericolanti, classe I, Scienze Fisiche Matematiche e Naturali, 67:41-77.

Saidova, K.M. 1981. O Sovremennom Sostoyanii Sistemy Nadvidovykh Taksonov Kaynozoyskikh Bentosnykh Foraminifer. Institut Okeanologii P.P. Shirshova, Akademiya Nauk SSSR, Moscow. [In Russian]

Salvi, G., Buosi, C., Arbulla, D., Cherchi, A., De Giudici, G., Ibba, A., and De Muro, S. 2015. Ostracoda and Foraminifera response to a contaminated environment: the case of the Ex- 
Military Arsenal of the La Maddalena Harbour (Sardinia, Italy). Micropaleontology, 61:115133.

Sars, G.O. 1866. Översigt af Norges Marine Ostracoder. Forhandlinger I Videnskabs, Selskabet I Christiania.

Sars, G.O. 1925. An Account of the Crustacea of Norway (Volume 9), p. 137-208. Bergen Museum, Bergen.

Sars, G.O. 1928. An Account of the Crustacea of Norway (Volume 9), p. 241-277. Bergen Museum, Bergen.

Scacchi, A. 1841. Notizie geologiche sulle conchiglie che si trovan fossili nell'isola d'Ischia e lungo la spiaggia tra Pozzuoli e Monte Nuovo. Antologia di Scienze Naturali Pubblicata da R. Piria ed A. Scacchi, Napoli, 1:33-48.

Scacchi, A. 1849. Memorie geologiche sulla Campania. Memoria II. Descrizione geologica della Regione flegrea. Rendiconto della Reale Accademia delle Scienze di Napoli, 8:115-140.

Scarpati, C., Cole, P., and Perrotta, A. 1993. The Neapolitan Yellow Tuff. A large volume multiphase eruption from Campi Flegrei, southern Italy. Bulletin of Volcanology, 55:343-356. https://doi.org/10.1007/bf00301145

Schlumberger, C. 1881. In Milne-Edwards, A., Compte rendu sommaire d'une exploration zoologique, faite dans le Me?diterrane?e a? bord du navire de l'Etat "Le Travailleur". Comptes Rendus Hebdomadaires des Se?ances de l'Acade?mie des Sciences, 93:876-882.

Schlumberger, C. 1894. Note sur les foraminifères des mers arctiques russes. Mémoires de la Société Zoologique de France, 7:252-258.

Schmiedl, G., de Bovée, F., Buscail, R., Charrière, B., Hemleben, C., Medernach, L., and Picon, P. 2000. Trophic control of benthic foraminiferal abundance and microhabitat in the bathyal Gulf of Lions, western Mediterranean Sea. Marine Micropaleontology, 40:167-188. https:// doi.org/10.1016/s0377-8398(00)00038-4

Schmiedl, G., Mitschele, A., Beck, S., Emeis, K.-C., Hemleben, C., Schulz, H., Sperling, M., and Weldeab, S. 2003. Benthic foraminiferal record of ecosystem variability in the eastern Mediterranean Sea during times of sapropel S5 and S6 deposition. Palaeogeography, Palaeoclimatology, Palaeoecology, 190:139-164. https://doi.org/10.1016/s00310182(02)00603-X

Schneider, S., Witt, W., and Yigitba?, E. 2005. Ostracods and bivalves from an Upper Pleistocene (Tyrrhenian) marine terrace near Altinova (?zmit Province, Turkey). Zitteliana, A45:87-114.

Schornikov, E.I. 1969. Podklass Ostracoda, ili rakushkovye rachki, Ostracoda Latreille, 1806. Opredelitel fauny Chernogo i Azovogo Morey, 2:163-259. [In Russian]

Schultze, M.S. 1854. U?ber den Organismus der Polythalamien (Foraminiferen), nebst Bermerkungen u?ber die Rhizopoden im Allgemeinen. Wilhelm Engelmann, Leipzig.

Schwager, C. 1866. Fossile Foraminiferen von Kar Nikobar, p. 187-268. In Reise der österreichschen Fregatte Novara um die Erde in den Jahren 1857, 1858, 1859; Geologischer Theil 2 (2. Abt.), Kaiserlich-königliche Staatsdruckerei, Wien.

Schwager, C. 1876. Saggio di una classificazione dei foraminiferi avuto riguardo alle loro famiglie naturali. Bolletino del Reale Comitato Geologico d'Italia, 7:475-485.

Schweizer, M., Jorissen, F., and Geslin, E. 2011. Contributions of molecular phylogenetics to foraminiferal taxonomy: general overview and example of Pseudoeponides falsobeccarii Rouvillois, 1974. Comptes Rendus Palevol, 10:95-105. https://doi.org/10.1016/ j.crpv.2011.01.003

Schweizer, M., Pawlowski, J., Kouwenhoven, T.J., and van der Zwaan, B. 2009. Molecular phylogeny of common cibicidids and related Rotaliida (Foraminifera) based on small subunit rDNA sequences. Journal of Foraminiferal Research, 39:300-315. https://doi.org/10.2113/ gsjfr.39.4.300

Seguenza, G. 1862. Prime ricerche intorno ai rizopodi fossili delle argille pleistoceniche dei dintorni di Catania. Atti Accademia Gioenia Scienze Naturali in Catania, 2:84-126.

Seguenza, G. 1880. Le formazioni terziarie della provincia di Reggio (Calabria). Atti della Reale Accademia Nazionale dei Lincei, (Series 3), 6:3-446. https://doi.org/10.5962/bhl.title.40049

Seiglie, G.A. 1965. Some observations on Recent foraminifers from Venezuela. Part I. Contributions from the Cushman Foundation for Foraminiferal Research, 16:70-73.

Seiglie, G.A. and Bermudez, J. 1965. Monografia de la familia de foraminiferos Glabratellidae. Geos, 12:15-64. 
Sellier de Civrieux, J.M. 1977. Las Discorbidae del Mar Caribe, frente a Venezuela. Cuadernos Oceanogra?ficos, Universidad de Oriente, Cumana, 6:1-44.

Sen Gupta, B.K., Lobegeier, M.K., and Smith, L.E. 2009a. Foraminiferal Communities of Bathyal Hydrocarbon Seeps, Northern Gulf of Mexico: A taxonomic, Ecologic, and Geologic Study. U.S. Dept. of the Interior, Minerals Management Service, Gulf of Mexico OCS Region, New Orleans, LA. OCS Study MMS 2009-013

Sen Gupta, B.K. and Platon, E. 2006. Tracking past sedimentary records of oxygen depletion in coastal waters: use of the Ammonia-Elphidium Foraminiferal Index. Journal of Coastal Research, Special Issue 39. Proceedings of the 8th International Coastal Symposium (ICS 2004), 3:1351-1355.

Sen Gupta, B.K., Smith, L.E., and Machain-Castillo, M.L. 2009b. Foraminifera of the Gulf of Mexico, p. 87-129. In Felder, D.L. and Camp, D.K. (eds.), Gulf of Mexico. Origins, Waters, and Biota Biodiversity. Texas A\&M University Press, College Station, Texas.

Sen Gupta, B.K., Turner, R.E., and Rabalais, N.N. 1996. Seasonal oxygen depletion in continental-shelf waters of Louisiana: historical record of benthic foraminifers. Geology, 24:227-230. https://doi.org/10.1130/0091-7613(1996)024\%3C0227:sodics\%3E2.3.co;2

Sgarrella, F. 1992. Revision of Brizalina aenariensis Costa, 1856 (Foraminiferida). Bollettino della Società Paleontologica Italiana, 31:317-323.

Sgarrella, F. and Moncharmont Zei, M. 1993. Benthic Foraminifera of the Gulf of Naples (Italy): systematics and autoecology. Bollettino della Società Paleontologica Italiana, 32:145-264.

Sidebottom, H. 1908. Report on recent Foraminifera on the coast of the Island of Delos (Grecian Archipelago). Part 5. Memoirs and Proceeding of the Manchester Literary and Philosophical Society (Manchester Memoirs), 52:1-29.

Sigal, J. 1952. Aperc?u stratigraphique sur la micropale?ontologie du Cre?tace?. XIX Congre?s Ge?ologique International, Monographies Re?gionales, Series 1, Alge?rie, 26:1-47.

Silvestri, A. 1896. Foraminiferi pliocenici della Provincia di Siena, parte I. Memorie della Pontificia Accademia Romana dei Nuovi Lincei, 12:1-204.

Silvestri, A. 1923. Lo stipite della Elissoforme e le sue affinita?. Memorie della Pontificia Accademia della Scienze, Nuovi Lincei, (Series 2), 6:231-270.

Sissingh, W. 1972. Late Cenozoic Ostracoda of the South Aegean Island Arc. Utrecht Micropaleontological Bulletins, 7:1-187.

Smith, R.K. 1987. Fossilization potential in modern shallow-water benthic foraminiferal assemblages. Journal of Foraminiferal Research, 17:117-122. https://doi.org/10.2113/ gsjfr.17.2.117

Smith, V.C., Isaia, R., and Pearce, N.J.G. 2011. Tephrostratigraphy and glass compositions of post-15 kyr Campi Flegrei eruptions: implications for eruption history and chronostratigraphic markers. Quaternary Science Reviews, 30:3638-3660. https://doi.org/10.1016/ j.quascirev.2011.07.012

Stefanelli, S. 2004. Cyclic changes in oxygenation based foraminiferal microhabitats: EarlyMiddle Pleistocene, Lucania Basin (southern Italy). Journal of Micropaleontology, 23:81-95. https://doi.org/10.1144/jm.23.1.81

Stefanelli, S. and Capotondi, L. 2008. Foraminiferal response to the deposition of insolation cycle 90 sapropel in different Mediterranean areas. Journal of Micropalaeontology, 27:45-61. https://doi.org/10.1144/jm.27.1.45

Stubbies, S.J., Green, J.C., Hart, M.B., and Williams, C.L. 1996. The ecological and palaeoecological implications of the presence and absence of data: evidence from benthic Foraminifera. Proceedings of the Ussher Society, 9:54-62.

Swain, F.M. and Gilby, J.M. 1974. Marine Holocene Ostracoda from the Pacific coast of North and Central America. Micropaleontology, 20:257-352. https://doi.org/10.2307/1484940

Sylvester-Bradley, P.C. 1948. The ostracode genus Cythereis. Journal of Paleontology, 22: $792-$ 797.

Szarek, R. 2001. Biodiversity and Biogeography of Recent Benthic Foraminiferal Assemblages in the South-Western South China Sea (Sunda Shelf). Dissertation zur Erlangung des Doktorgrades der Mathematisch-Naturwissenschaftlichen Fakultät der Christian-AlbrechtsUniversität zu Kiel.

Tarasov, V.G., Gebruk, A.V., Shulkin, V.M., Kamenev, G.M., Fadeev, V.I., Kosmynin, V.N., Malakhov, V.V., Starynin, D.A., and Obzhirov, A.I. 1999. Effect of shallow-water hydrothermal venting on the biota of Matupi Harbour (Rabaul Caldera, New Britain Island, Papua New 
Guinea). Continental Shelf Research, 19:79-116. https://doi.org/10.1016/s02784343(98)00073-9

Terquem, O. 1875. Essai sur le classement des animaux qui vivent sur la plage et dans les environs de Dunkerque. Premiere partie. Mémoires de la Société Dunkerquoise pour l'Encouragement des Sciences des Lettres et des Arts, 19:405-457.

Terquem, M.O. 1878. Les foraminifères et les entomostracés-ostracodes du Pliocène supérieur de l'île de Rhodes. Mémoires de la Société Géologique de France, 3:1-135.

Thalmann, H.E. 1951. Mitteilungen u?ber Foraminiferen IX. Eclogae Geologicae Helvetiae, 43:221-225.

Todd, R. 1958. Foraminifera from the Western Mediterranean deep-sea cores. Reports of the Swedish Deep-Sea Expedition, Sediment Cores from the Mediterranean Sea and the Red Sea, 8:167-215.

Triebel, E. 1952. Ostracoden der Gattung Cytheretta aus dem Tertiär des Mainzer Beckens. Notizblatt des hessischen Landesamtes für Bodenforschung, (Series 6), 3:15-30.

Tsujimoto, A., Nomura, R., Yasuhara, M., Yamazaki, H., and Yoshikawa, S. 2006. Impact of eutrophication on shallow marine benthic foraminifers over the last 150 years in Osaka Bay, Japan. Marine Micropaleontology, 60:258-268. https://doi.org/10.1016/ j.marmicro.2006.06.001

Uffenorde, H. 1972. Oekologie und jahreszeitliche Verteilung rezenter bentonischer Ostracoden des Limski kanal bei Rovinj (nördliche Adria). Göttinger Arbeiten zur Geologie und Paläontologie, 13:1-121.

Uliczny, F. 1969. Hemicytheridae un Trachyleberididae (Ostracoda) aus dem Pliozän der Insel Kephallinia (Westgriechenland). Dissertation zur Erlangung der Doktorwürde der Hohen Narturwissenschaftlichen Fakultät der Ludwig-Maximilians Universität zu München.

Uthicke, S., Momigliano, P., and Fabricius, K.E. 2013. High risk of extinction of benthic foraminifera in this century due to ocean acidification. Scientific Reports, 3:1-5. https:// doi.org/10.1038/srep01769

Van Marle, L.J. 1991. Eastern Indonesian, Late Cenozoic Smaller Benthic Foraminifera. Verhandelingen der koninklijke Nederlandse Akademie van Wetenschappen, Afd. Letterkunde Eerste Reeks, 34, Amsterdam.

Vella, P. 1957. Studies in New Zealand Foraminifera. Paleontological Bulletin, 28:1-64.

Vilela, C.G., Batista, D.S., Batista-Neto, J.A., Crapez, M., and MCallister, J.J. 2004. Benthic foraminifera distribution in high polluted sediments from Nitero?i Harbor (Guanabara Bay), Rio de Janeiro, Brazil. Anais da Academia Brasileira de Ciências, 76:161-171. https://doi.org/ 10.1590/s0001-37652004000100014

Vitale, S. and Isaia, R. 2014. Fractures and faults in volcanic rocks (Campi Flegrei, southern Italy): Insight into volcano-tectonic processes. International Journal of Earth Sciences, 103:801-819. https://doi.org/10.1007/s00531-013-0979-0

Voloshinova, N.A., 1952. Pseudoparellinae, p. 80. In Voloshinova, N.A. and Dain, L.G. 1952. Iskopaemye Foraminifery SSSR. Nonionidy, Kassidulinidy I Khilostomellidy. Trudy, Vsesoyuznogo Neftyanogo Nauchnoissledovatel'skogo Geologo-razvedochnogo Instituta (VNIGRI), (New Series), 63:1-151. [In Russian]

Voloshinova, N.A. 1960. Uspekhi mikropaleontologii v dele izucheniya vnutrennego stroeniya foraminifer, p. 48-87. In Trudy Pervogo Seminara po Mikrofaune. Vsesoyuznyy Neftyanoy Nauchnoissledovatel'skii Geologorazvedochnyy Institut (VNIGRI). [In Russian]

Wagner, C.W. 1957. Sur les Ostracodes du Quaternaire Récent des Pays-Bas et Leur Utilisation dans l'Étude Géologique des Dépots Holocènes. Université de Paris.

Walker, G. and Jacob, E. 1798. In Kanmacher, F. (ed.), Adam's Essay on the Microscope. Dillon and Keating, London.

Wall-Palmer, D., Jones, M.T., Hart, M.B., Fisher, J.K., Smart, C.W., Hembury, D.J., Palmer, M.R., and Fones, G.R. 2011. Explosive volcanism as cause for mass mortality of pteropods. Marine Geology, 282:231-239. https://doi.org/10.1016/j.margeo.2011.03.001

Wedekind, P.R. 1937. Einfu?hrung in die Grundlagen der Historischen Geologie. Band II. Mikrobiostratigraphie die Korallen- und Foraminiferenzeit. Ferdinand Enke, Stuttgart.

Wiesner, H. 1920. Zur Systematik der Miliolideen. Zoologischer Anzeiger, 51:13-20.

Williamson, W.C. 1848. On the recent British species of the genus Lagena. The Annals and Magazine of Natural History, (Series 2), 1:1-20. https://doi.org/10.1080/03745485809494465

Williamson, W.C. 1858. On the recent Foraminifera of Great Britain. Ray Society, London. https:/ /doi.org/10.5962/bhl.title.139719 
Yanko, V., Arnold, A.J., and Parker, W.C. 1999. Effects of marine pollution on benthic Foraminifera, p. 217-235. In Sen Gupta, B.K. (ed.), Modern Foraminifera. Kluwer Academic Publishers, Great Britain. https://doi.org/10.1007/0-306-48104-9_13

Yassini, I. 1979. The littoral system ostracodes from the bay of Bou-Ismail, Algiers, Algeria. Revista Española de Micropaleontología, 11:353-416.

Zeppilli, D. and Danovaro, R. 2009. Meiofaunal diversity and assemblage structure in a shallowwater hydrothermal vent in the Pacific Ocean. Aquatic Biology, 5:75-84. https://doi.org/ $10.3354 / a b 00140$ 


\section{APPENDIX 1.}

Benthic foraminifer and ostracod list of species; * indicates allochthonous species.

\section{List of benthic foraminifer species}

Adelosina longirostra (d'Orbigny, 1826)

Ammonia aberdoveyensis Haynes, 1973 lobate form

Ammonia aberdoveyensis Haynes, 1973 rounded form

Ammonia beccarii (Linnaeus, 1758)

Ammonia falsobeccarii (Rouvillois, 1974)

Amphicoryna scalaris (Batsch, 1791)

Asterigerinata adriatica Haake, 1977

Asterigerinata mamilla (Williamsom, 1858)

Asterigerinata mariae Sgarrella, 1990

Astrononion stelligerum (d'Orbigny, 1839)

Aubignyna perlucida (Heron-Allen and Earland, 1913)

Bolivina catanensis Seguenza, 1862

Bolivina cistina Cushman, 1936

Bolivina ? earlandi Parr, 1950

Bolivina lowmani Phleger and Parker, 1951

Bolivina pseudoplicata Heron-Allen and Earland, 1930

Bolivina variabilis (Williamson, 1858)

Brizalina aenariensis Costa, 1856

Brizalina difformis (Williamson, 1858)

Brizalina spathulata (Williamson, 1858)

Brizalina striatula Cushman, 1922

Buccella granulata (Di Napoli Alliata, 1952)

Bulimina aculeata d'Orbigny, 1826

Bulimina elongata d'Orbigny, 1846

Bulimina marginata d'Orbigny, 1826

Cancris auricula (Fichtel and Moll, 1798)

Cassidulina carinata Silvestri, 1896

Cassidulina obtusa Williamson, 1858

Cibicides lobatulus (Walker and Jacob, 1798)

Cornuspira involvens (Reuss, 1850)

Discorbinella bertheloti (d'Orbigny, 1839)

Elphidium advenum (Cushman, 1922)

Elphidium articulatum (d'Orbigny, 1839)

Elphidium complanatum var. tyrrhenianum Accordi, 1951

Elphidium crispum (Linnaeus, 1758)

Elphidium granosum (d'Orbigny, 1826)

Elphidium incertum (Williamson, 1858)

Elphidium macellum (Fichtel and Moll, 1798)

Elphidium maioricense Colom, 1942

Elphidium poeyanum (d'Orbigny, 1839) DS form

Elphidium poeyanum (d'Orbigny, 1839) FS form

Elphidium pulvereum Todd, 1958

Elphidium punctatum (Terquem, 1878)
Epistominella vitrea Parker, 1953

Evolvocassidulina bradyi (Norman, 1881)

Fissurina ? laevigata Reuss, 1850

Fissurina nummiformis (Buchner, 1940)

Fursenkoina subacuta (d'Orbigny, 1852)

Fursenkoina tenuis (Seguenza, 1862)

Gavelinopsis praegeri (Heron-Allen and Earland, 1913)

Glabratella erecta (Sidebottom, 1908)

Glabratella hexacamerata Seiglie and Bermúdez, 1965

Glandulina laevigata (d'Orbigny, 1826)

Globocassidulina subglobosa (Brady, 1881)

Globulina minuta (Roemer, 1838)

Grigelis guttiferus (d'Orbigny, 1846)

Haynesina depressula (Walker and Jacob, 1798)

Haynesina germanica (Ehrenberg, 1840)

Hyalinonetrion clavatum (d'Orbigny, 1846)

Laevidentalina communis (d'Orbigny, 1826)

Lagena semistriata Williamson, 1848

Lagena striata (d'Orbigny, 1839)

Lamarckina scabra (Brady, 1884)

Lenticulina sp.

Marginulina similis d'Orbigny, 1846

Melonis affinis (Reuss, 1851)

Neolenticulina peregrina (Schwager, 1866)

Nonion fabum (Fichtel and Moll, 1798)

Nonion sp.

Nonionella turgida (Williamson, 1858)

Oolina hexagona (Williamson, 1848)

Oolina sp.

Parrellina verriculata (Brady, 1881)

Procerolagena gracilis (Williamson, 1848)

Quinqueloculina parvula Schlumberger, 1894

Quinqueloculina pygmaea Reuss, 1850

Quinqueloculina seminulum (Linnaeus, 1758)

Rectuvigerina phlegeri Le Calvez, 1959

Reussella spinulosa (Reuss, 1850)

Reussoolina laevis (Montagu, 1803)

Robertina traslucens Cushman and Parker, 1936

Rosalina floridana (Cushman, 1922)

Rosalina macropora (Hofker, 1951)

Rosalina obtusa d'Orbigny, 1846

Rotorbis auberii (d'Orbigny, 1839)

Sigmoilinita distorta (Phleger and Parker, 1951)

Stainforthia complanata (Egger, 1893)

Tretomphalus concinnus (Brady, 1884)

Trifarina angulosa (Williamson, 1858)

Triloculina trigonula (Lamarck, 1804) 
Valvulineria bradyana (Fornasini, 1900)

Valvulineria sp. 1

\section{List of ostracod species}

Acanthocythereis hystrix (Reuss, 1850)

Aurila convexa (Baird, 1850)

Aurila prasina Barbeito-Gonzalez, 1971

Aurila sp.

Callistocythere badia Bonaduce, Ciampo and

Masoli, 1976

Callistocythere flavidofusca (Ruggieri, 1950)

Callistocythere littoralis (Müller, 1894)

Callistocythere sp.

${ }^{*}$ Candona neglecta Sars, 1887

${ }^{*}$ Candonidae

Carinocythereis whitei (Baird, 1850)

Cistacythereis (Hiltermannicythere) turbida (Müller, 1894)

Costa edwardsi (Roemer, 1838)

${ }^{*}$ Cyclocypris sp.

${ }^{*}$ Cypria sp.

${ }^{*}$ Cyprideis torosa (Jones, 1850)

${ }^{*}$ Cypridopsis sp.

${ }^{*}$ Cypris pubera O.F. Müller, 1776

Cytheretta adriatica Ruggieri, 1952

Cytheretta subradiosa (Roemer, 1838)

Cytheridea neapolitana Kollmann, 1960

Cytherois ? valkanovi Klie, 1937

Cytheromorpha nana Bonaduce, Ciampo and Masoli, 1976

"Elofsonia" minima (Bonaduce, Ciampo and Masoli, 1976)

Eucythere curta Ruggieri, 1975

Eucytherura gibbera Müller, 1894

Eucytherura mistrettai Sissingh, 1972

Hemicytherura defiorei Ruggieri, 1953

Hemicytherura videns (Müller, 1894)

*Heterocypris sp.

Leptocythere macella Ruggieri, 1975

Leptocythere ramosa (Rome, 1942)

Loxoconcha aff. L. elliptica Brady, 1868

Loxoconcha gibberosa Terquem, 1878

Loxoconcha ovulata (Costa, 1853)
Loxoconcha ? rubritincta Ruggieri, 1964

Loxoconcha sp.

Microcytherura angulosa (Seguenza, 1880)

Microcytherura fulva (Brady and Robertson, 1874)

Microcytherura sp.

*Mixtacandona sp.

Neonesidea aff. N. longevaginata (Müller, 1894)

Palmoconcha turbida (Müller, 1912)

Paracytheridea paulii Dubowsky, 1939

Paracytheridea triquetra (Reuss, 1850)

Pontocypris pellucida Müller, 1894

Pontocythere turbida (Müller, 1894)

Procytherideis retifera Ruggieri, 1978

Procytherideis subspiralis (Brady, Crosskey and

Robertson, 1874)

*Pseudocandona sarsi (Hartwig, 1899)

Pseudocytherura strangulata Ruggieri, 1991

Pseudocytherura sp.

Pseudopsammocythere reniformis (Brady, 1868)

Pterygocythereis coronata (Roemer, 1838)

Pterygocythereis jonesii (Baird, 1850)

Rectobuntonia subulata (Ruggieri, 1954)

Sagmatocythere versicolor (Müller, 1894)

Sagmatocythere sp.

Sahnicythere retroflexa (Klie, 1936)

Semicytherura alifera Ruggieri, 1959

Semicytherura dispar (Müller, 1894)

Semicytherura incongruens (Müller, 1894)

Semicytherura paradoxa (Müller, 1894)

Semicytherura rara (Müller, 1894)

Semicytherura rarecostata Bonaduce, Ciampo and Masoli, 1976

Semicytherura ruggierii (Pucci, 1955)

Semicytherura sulcata (Müller, 1894)

Urocythereis margaritifera (Müller, 1894)

Urocytherideis ilariae Aiello, Barra and Parisi, 2016

Xestoleberis communis G.W. Müller, 1894

Xestoleberis dispar Müller, 1894

Xestoleberis ? rara Müller, 1894

Asterisk indicates taxa recognized as allochthonous. 